\title{
FREDRIK LILJA
}

WHIP OF THE VINE

Labour relations and the role of alcohol in Western Cape wine farming from the 1940s to the 2010s

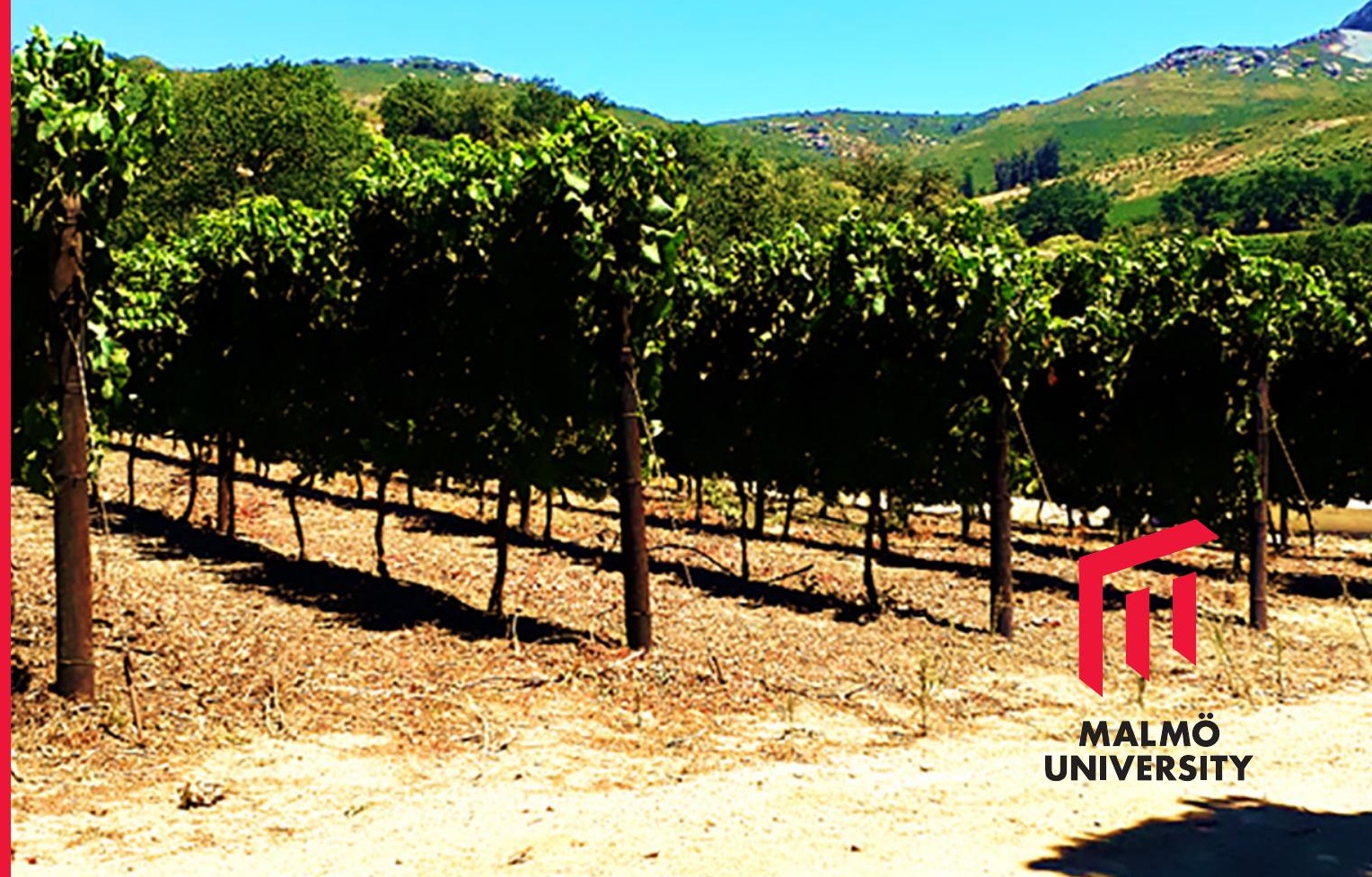



WHIP OF THE VINE 
Skrifter med historiska perspektiv No. 20

(C) Copyright Fredrik Lilja 2019

Cover photo by Sheila Lilja

ISBN 978-91-7104-977-3 (print)

ISBN 978-91-7104-978-0 (pdf)

Holmbergs, Malmö 2019 


\section{FREDRIK LILJA}

\section{WHIP OF THE VINE}

Labour relations and the role of alcohol in Western Cape wine farming from the 1940s to the 2010s 
This publication is available electronically at, muep.mau.se 



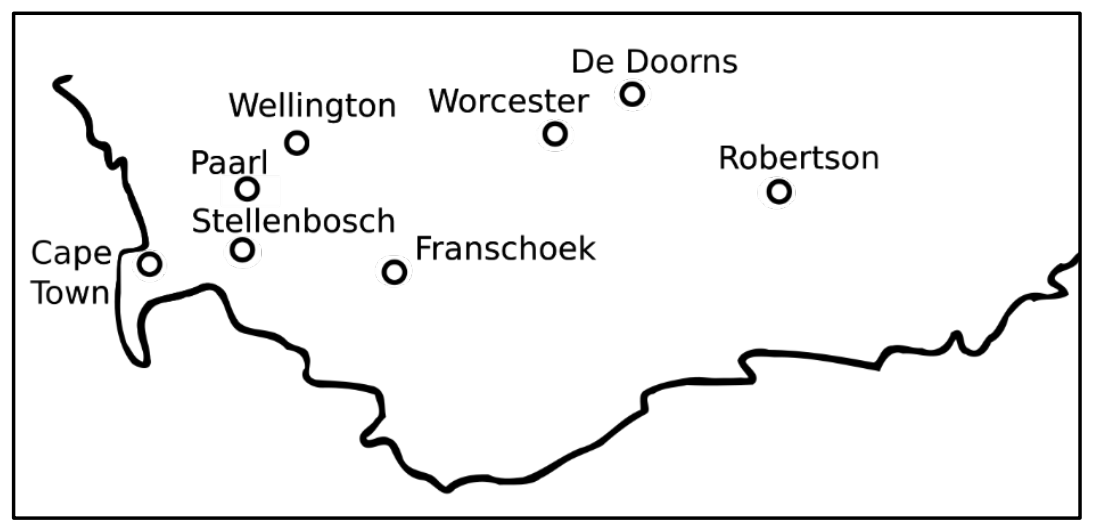

The Cape winelands. 


\section{CONTENTS}

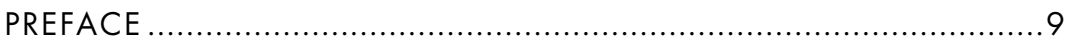

1. WINE FARMING AND ALCOHOL ABUSE ............................ 11

Wine and farm labour in the Western Cape .............................................. 11

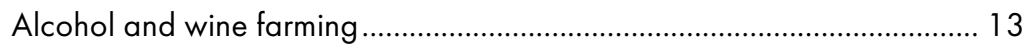

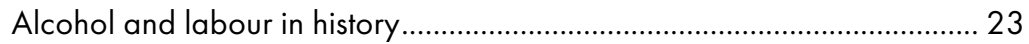

2. THE POLITICAL ECONOMY OF WINE FARMING IN THE

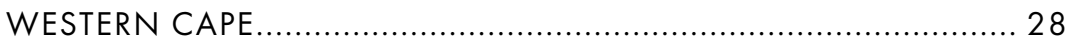

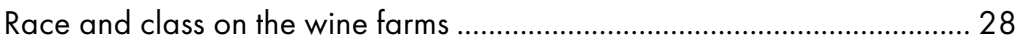

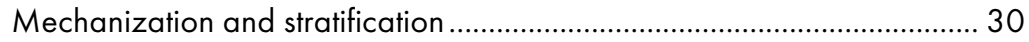

Permanent and seasonal labour in the rural class struggle ........................ 32

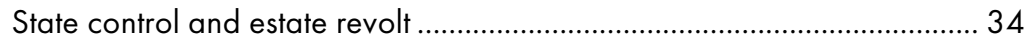

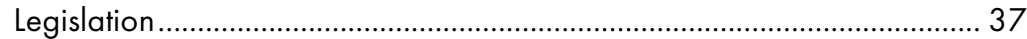

3. THE DOP SYSTEM AND DRUNKENNESS IN THE CAPE -

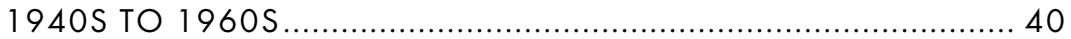

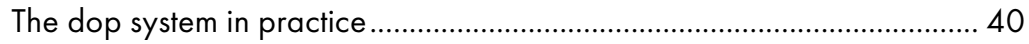

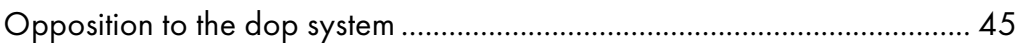

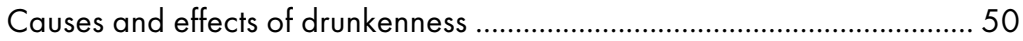

Sobriety and labour - the view of labourers................................................ 56

Farmers who refused the system ............................................................... 58

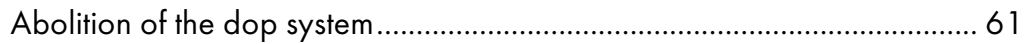

4. WINDS OF CHANGE - TRANSFORMATION OF PRODUCTION AND LABOUR, 1950S TO 1990S .........................6 64

The labour force - race, gender and wages ..............................................64

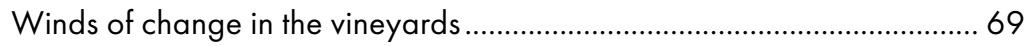

Harvest time and new technology ............................................................. 72

Division of labour, skills and training ........................................................... 76 
Division of labourers - management and individualization of labour 81

Productivity, profits and stratification of the labour force

5. TRADE UNIONS, SANCTIONS AND IMPROVED

CONDITIONS ON FARMS ................................................. 93

Getting the house in order - trade unions are coming to the farm ............. 93

Keeping politics away from farming ......................................................... 100

The impact of sanctions .......................................................................... 108

6. NEW CONDITIONS FOR CAPITAL ACCUMULATION WINE FARMING AND LABOUR RELATIONS IN THE POST-

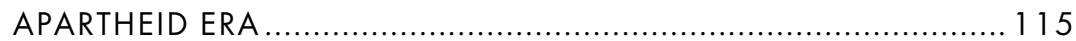

Deregulation and competition on the international market....................... 115

The new labour relations......................................................................... 123

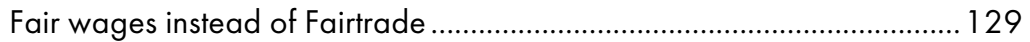

The disappearance of the dop system ........................................................ 133

The "soft tot" and responsible labourers................................................... 137

7. INSIDE THE FARM GATES AND OUTSIDE - HOUSING,

LOYALTY AND SECURITY FOR FARM LABOURERS .................... 146

Housing for farm labourers - investment, control and costs .................... 146

Independence and dependence ............................................................ 150

Understanding the isolation - challenges for trade unions ....................... 153

Farm labourers organizing against trade unions ................................... 157

8. THE STRUGGLE OVER FARM LABOURERS - ALCOHOL ABUSE

AND SOCIAL UPLIFTMENT IN THE POST-APARTHEID ERA …............ 162

Cheap alcohol and the legacy of the dop system .................................... 162

New generation and old habits .............................................................. 167

Mechanization, diversification of labourers and alcohol problems......... 170

Benefactors and the role of the individual ................................................ 175

Upliftment, empowerment and fairness..................................................... 179

Treatment and coordination of efforts ....................................................... 182

The voice of farm labourers ..................................................................... 185

9. CONTINUITY AND CHANGE ON WINE FARMS .................. 194

SOURCES AND LITERATURE ............................................. 206

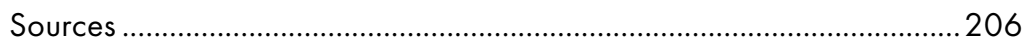

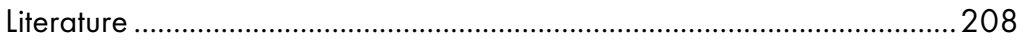

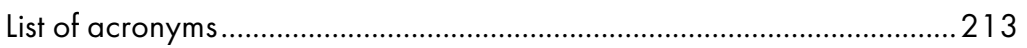

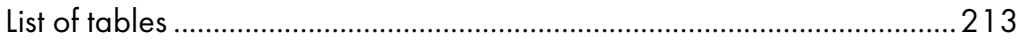




\section{PREFACE}

Research for this book was done in 2013 when the dust from the farm labour strikes earlier that year had just begun to settle in the Western Cape. Issues of working conditions on farms have emerged in the public debate from time to time since then, both in South Africa and in countries such as Sweden, where much of the wine produced in the Western Cape ends up. Questions of exploitation and the human cost of producing wine have been at the centre of such discussions and I hope this book can contribute with new perspectives. If successful, the book will illuminate central aspects of the transformations that have occurred in wine farming since the mid-twentieth century, which must be considered in order to understand relations on farms today. The book is part of a project at Malmö University funded by SIDA through the Swedish Research Council's Division for Development Research.

Several people have contributed to and facilitated the research. Lars Olsson, who headed the project, and Jonas Sjölander have provided both valued comments and company and deserve special thanks. Joachim Ewert, Gavin Williams and Andries du Toit have generously shared their knowledge about the wine industry. Niklas Almesjö and Sheila Lilja have assisted with the map. Mats Greiff and Johan Lundin have assisted in the publishing process. Lastly, thanks to my family and especially to my dad Anders Lilja and my wife Sheila.

Uppsala, December 2018.

Fredrik Lilia 


\section{WINE FARMING AND ALCOHOL ABUSE}

\section{Wine and farm labour in the Western Cape}

Since the seventeenth century, alcohol has played an important role in the formation and reproduction of relations based on class and race in South Africa. In the Cape winelands, where white farmers for centuries gave rations of wine to the largely coloured labour force in the infamous dop (or tot) system, it has been especially evident how alcohol has contributed to both wealth and subjugation. The dop system was initiated in the days of slavery in order to create docile labourers and continued until the late twentieth century, although it was banned in the 1960s. In 1996, President Nelson Mandela denounced it and called for the wine industry to end the “"[...] last remnants of the tot system'”. ${ }^{1}$ It has since then largely disappeared, although occasional reports of its continued existence have emerged from time to time. But while the practice of the past is not widespread in the twenty-first century, the alcohol abuse and social problems related to it, are still indeed common.

The prevalence of the dop system has generally been regarded as a cause of alcoholism among coloureds in the rural areas of the Western Cape, the province with the highest level of alcohol dependency in South Africa. ${ }^{2}$ But despite the important role of the dop system, little is known about how it transformed during the later half of the twentieth century, how and why it diminished and finally disappeared, and how this affected labour relations on

\footnotetext{
${ }^{1}$ London, 1999, p. 1412. For the early history of the dop system, see Williams, 2016.

${ }^{2}$ See London, 2000.
} 
farms. The purpose of this book is therefore to analyse the role of alcohol in Western Cape wine farming from the 1940s to the 2010s in an attempt to explain the decreasing use of the dop system, how its replacement has impacted labour relations on farms, and how alcohol problems have been managed.

In order to understand the role of the dop system and alcohol use and abuse in wine farming, we must contextualize the issue within the political economy of wine farming. As Gavin Williams points out, in the period up to the late nineteenth century, the dop system was closely intertwined with the labour market and farmers' control of their labour force. ${ }^{3}$ For this book, the economic, political and social factors that have determined power relations on farms since the 1940s will thus be essential. The decline of the dop system during the late twentieth century indicates that the old practices were no longer advantageous for accumulation of capital. Since wine farming in the Western Cape has been particularly successful during the years after apartheid, there is also reason to assume that farmers have found new methods for this purpose. But not all farmers have been able to make substantial profits; many of them have been struggling after the deregulation of the South African wine industry in the $1990 \mathrm{~s}$, which exposed farmers to international competition. ${ }^{4}$ It will therefore be important to consider how the new conditions for capitalist farming during the twenty-first century have affected not only the labour force, but also farmers' ability to accumulate capital.

In the southern African context, the relations formed on farms and in rural areas have been at the centre of the colonial history. The colonial and capitalist expansion in the region was based on white settlers' access to land, which was achieved through dispossession of black and coloured people, who were forced into farm labour. ${ }^{5}$ A focus on farm labour thereby adds much to our understanding of both capitalist production and South African society. But doing so implies that we have to consider the specific social and racial relations on Western Cape farms. Due to its large popu-

\footnotetext{
${ }^{3}$ Williams, 2016, p. 909.

${ }^{4}$ See Viall et al., 2011, p. 92.

${ }^{5}$ See Bundy, 1979; Lilja, 2013.
} 
lation of coloureds, i. e. those with mixed heritage from slaves, Khoisan and whites, who have been categorized separately from the Bantu-speaking blacks, the Western Cape differs from the rest of the country. The coloured farm labourers have been seen as a group dependent on, and to some extent loyal with, white farmers. The paternalist structure on farms, with the white farmer as a paternal figure, has been at the centre of this relationship of dependence and subjugation, which has been formed during hundreds of years. In the words of Andries du Toit, the farm has been regarded as a family, which both farmers and labourers belong to. ${ }^{6}$ As we shall see, alcohol has had no small part in the reproduction of paternalism and labour relations on Western Cape farms.

It must be pointed out that the dop system and alcohol dependency has been prevalent on all sorts of farms in the Western Cape. But it is relevant to focus on wine farming because it is the sector, from which the dop system originated, and it is the sector where the wine has been produced. Such a focus will, in addition, acknowledge how production of alcohol has been tied in with consumption and abuse of the same product.

\section{Alcohol and wine farming}

Except for scattered pieces of research, there have been few attempts to analyse alcohol abuse and the dop system historically. Pamela Scully's study of labour relations in wine farming during the late nineteenth and early twentieth century is the most extensive treatment of the issue. She contextualizes alcohol in the paternalist structure on wine farms and points out the central position of the dop system. Farmers provided housing and small plots of land for labourers, and also used wine as a method of tying labourers to the farm, especially for the picking season. It was particularly the poorer farmers who relied on wine as payment. Those

with capital assets could instead rely more on cash wages. ${ }^{7}$ Lars Olsson agrees with Scully, but also notes that giving wine did not always secure the best quality of labourers and that the more successful farmers instead relied on a form of labour tenancy, where

\footnotetext{
${ }^{6}$ See Du Toit, 1993.

${ }^{7}$ Scully, 1990, pp. 52-55. 65.
} 
labourers were given plots of land to cultivate on, to attract labour. $^{8}$

In this regard, it is also important to note that paternalist relations developed along with increased capitalist farming. One reason for this, as Scully reminds us, was that farmers were not satisfied with the "free" wage labour, since it was harder to control that kind of labour force than the one they had during slavery. ${ }^{9}$ As Williams notes, wine was used to attract labourers back to farms after emancipation. ${ }^{10}$ It was thus used by farmers to retain social control over labourers.

Already during the late nineteenth century, the social problems related to the dop system were noticeable. Wine farmers complained about the drunkenness among labourers, but also acknowledged that they would not be able to find labour unless they gave rations of wine. ${ }^{11}$ Competition over labour from other sectors where wages were higher, such as mining and public works, created problems for farmers and meant that they had to rely more on coercive measures such as tied rent and wine as wages in order to secure labour. These practices tied labourers to the farm, and to the farmer as a person. Ultimately, the practices resulted in labourers becoming indebted and addicted to alcohol. There were also farmers who wanted to reduce the dop system and change remunerative practices, though. Especially those who mechanized their farming operations were prepared to pay higher cash wages instead. By 1910, the labour supply was, however, more favourable to farmers, since public works did not demand as much labour as previously and the migration of black people to the region had increased. $^{12}$

While the dop system was a central part of the paternalist relations upon which many farmers relied, it was not entirely controlled by farmers. Scully argues that farmers supplied the wine, but were not part of the social environment when labourers gathered to drink. In that regard, the dop system united the labourers

\footnotetext{
${ }^{8}$ Olsson, 2018, pp. 47, 62.

${ }^{9}$ Scully, 1990, p. 90.

${ }^{10}$ Williams, 2016, p. 908.

${ }^{11}$ Scully, 1990, p. 64.

${ }^{12}$ Scully, 1992, pp. 64-68, 72.
} 
and excluded the farmers, suggesting that the wine had a different meaning to the labourers, who saw themselves as being in control of the drinking. ${ }^{13}$ The system thereby appears to have continued not only due to the willingness of farmers to pay wages in wine, but also due to the labourers' desire for it. This is, of course, typical of addiction and illustrates how the dop system easily reproduced itself, since it created an addiction to alcohol. But it must be mentioned that alcohol dependency was not limited to farming areas. In fact, alcoholism was widespread in nineteenth and twentieth century Cape and South Africa. ${ }^{14}$ Consequently, other factors than the dop system contributed to alcohol dependency.

Wilfried Schärf's study of the role of alcohol in the Western Cape in the early 1980s considers many of these contributing factors, such as low wages and poor working conditions. He emphasizes the role played by coercive management, but also notes that the system was related to the notion that "heavy drinking is an acceptable recreational activity". ${ }^{15}$ Labourers therefore also contributed to the reproduction of the remunerative practices. Still, the impact was devastating for the labourers. Schärf suggests that it resulted in an "underskilling" for both work and life in general and

contributed to the underdevelopment of $[\ldots]$ the whole rural working class. They have been reproduced, with the aid of the tot, to suit the particular needs of winefarming capital. ${ }^{16}$

The definition of skill is not very clear in Schärf's study, but he follows the common line of reasoning based on the notion that the skill level required in farming was lower than in industries. Farmers therefore, he suggests, benefitted when labourers were "unskilled" and dependent on alcohol, since it kept them from going to urban industries.

The dop system seems to have been widespread in the 1980s. Schärf visited 18 farms for his study and the dop system was used to a greater or lesser extent on all of them. However, the system was not static, since he notes that the amount of alcohol in the dop

\footnotetext{
${ }^{13}$ Scully, 1992, p. 59.

${ }^{14}$ Mager, 2010, pp. 2, 67-68.

${ }^{15}$ Schärf, 1984, pp. 166-67.

${ }^{16}$ Schärf, 1984, p. 180.
} 
was reduced between the 1940 s and the 1980 s. $^{17}$ Schärf does not consider why, though, so we do not know the reasons for this decrease. No similar analysis has been made afterwards, but the system was reduced even further in the 1990s, when research estimated that it was used by 20 per cent of farmers at the most. ${ }^{18}$

The reduced role of the dop system must therefore be explained. Schärf's argument, that the system was used to "deskill" and to reproduce the labour force, is certainly valid, but only for the period up to the 1980s, if not before. According to Jan Theron, the dop system was in transition in the fruit farming area Citrusdal in the 1970s. For example, some farmers only gave wine during weekends and some offered higher cash wages instead. ${ }^{19} \mathrm{~A}$ farmer in the Hex River Valley similarly stated in the 1970s that half of all farmers in that area gave no tots of wine at all. ${ }^{20}$

One possible reason for the transformation of the dop system during the 1970s could have been that demands on labour began to change. Schärf notes that some farmers in Stellenbosch, who were not part of his study, had started to change their labour practices from what he calls coercive to cooptive during the 1980s. The cooptive methods included improved housing and sanitation, but also social facilities such as sports grounds, and the labourers were encouraged to take part in social activities. ${ }^{21}$ He claims that the dop system was "notably absent" on farms where cooptive mehods were used for reproduction of the labour force. ${ }^{22}$ The farmers who used cooptive methods hired labourers who were more skilled, had more education and could take responsibility. Some of the measures taken were costly, but would generate returns in the form of higher productivity. On such farms there was no room for the dop system in the 1980 s. $^{23}$

If we consider that the dop system had been used in the Western Cape for hundreds of years, it is remarkable that it could disappear

\footnotetext{
${ }^{17}$ Schärf, 1984, p. 155.

${ }^{18}$ London, 1999, p. 1410.

${ }^{19}$ Theron, 1976, p. 19; Saldru, 1977, p. 11.

${ }^{20}$ Saldru, 1977, p. 10.

${ }^{21}$ Schärf, 1984, pp. 196-97.

${ }^{22}$ Schärf, 1984, p. 149.

${ }^{23}$ Schärf, 1984, p. 196.
} 
within a few decades during the twentieth century. This quick transformation indicates that its role in reproduction of the labour force has been exaggerated or that other, more efficient, practices were introduced in the mid-twentieth century. Schärf notes some central aspects in the relationship between the dop system and capitalist farming and reproduction of labour, but he overlooks two crucial features: historical change and structural transformation. In other words, he does not consider that capitalism is a constantly changing structure and that the conditions for capital accumulation change over time. This study will bridge that gap by inserting the changing practices and the role of alcohol in a wider context of changing capitalist farming in South Africa during the period after the Second World War.

The use of cooptive methods was not only seen in wine farming. David Mayson shows that on some fruit farms in Elgin in the Western Cape in the 1980s, farmers raised living standards and invested in training for labourers. The purpose of these investments was to raise productivity by encouraging "more sober habits and stability on the farms". ${ }^{24}$ As a result of these transformations, the control over labour changed, according to Mayson. The old practice, wherein farmers' personal power over labourers determined labour relations - for example though access to land - was replaced by a system wherein labourers became involved in the success of the farm. In this cooptive practice, farmers told labourers that the profits of the farm were based on the performance of labourers and that they would benefit if the farm was profitable. ${ }^{25}$

By the 1980s, some farmers were obviously more interested in promoting sobriety among labourers and began to see the dop system as redundant. Other farmers continued with the practice, though. Leslie London notes that the dop system was mainly practiced on the smaller farms in the 1990s. ${ }^{26}$ By smaller, he probably means the less successful ones. It is also likely that the dop system continued into the twenty-first century, but in a different form. Susan Levine suggests that "some farmers" have continued to pay la-

\footnotetext{
${ }^{24}$ Mayson, 1990, p. 268.

${ }^{25}$ Mayson, 1990, p. 269.

${ }^{26}$ London, 2000, p. 201.
} 
bourers with wine after the end of apartheid and that they give wine as a gift to labourers instead of as part of the wage. ${ }^{27}$ This transformation, from paying wages with wine to giving wine as a gift, must be emphasized, since the latter implies that labour relations and remunerative practices in fact have changed. It also means that the role of alcohol has changed. Giving wine as a gift implies a greater cost for the farmer, since he also has to pay wages. But this transformation of the dop system also means that drinking did not take place in the production sphere and instead moved to a leisure sphere where the farmer has less control.

While the manner in which wine is given - as part of a wage or as a gift - is of importance for the relationship between farmers and labourers, there is another aspect which must be considered, namely the consumption of wine. The problems caused by alcohol in the Western Cape have been focused by researchers such as London. He argues that farm labourers in the Western Cape drink about twice as much as people in urban areas of the province. ${ }^{28}$ In a study of the deciduous fruit industry in the Western Cape, London notes the impact of the dop system. Those who had worked on farms where the dop system was used were ten times less likely to be abstainers than those who worked on farms where the dop system was not used. However, there was no relationship between the dop system and the age at which people began to drink. London attributes this to the "pervasive 'alcohol culture' in the region". ${ }^{29}$ Since the dop system has greatly contributed to that culture, it is thus possible to state that it has had a profound impact also on farms where the dop system is not used.

However, heavy drinking is not something exclusive to farm labourers in the Western Cape. In fact, the farm labourers in London's study drank less alcohol per day than what factory workers in Gauteng did. ${ }^{30}$ London offers no explanation as to why factory workers consume more alcohol than farm labourers, but it is obvious that various explanations must be taken into account when

\footnotetext{
${ }^{27}$ Levine, 2013, p. 26.

${ }^{28}$ London, 1999, p. 1409.

${ }^{29}$ London, 2000, p. 201.

${ }^{30}$ See London, 2000, p. 202 (34.8 compared to 37 grams).
} 
analysing high levels of drinking. Working class culture is one such aspect, which must be considered, but also the social circumstances surrounding the drinking are important. Factory workers are, unlike farm labourers, more independent from their employer in the sense that they do not live in the workplace in the way that farm labourers do. For factory workers, it is thus likely that there is no direct relationship between the workplace and the drinking.

The difference between alcohol use and abuse is not always clear cut. For example, in South Africa alcohol use is most common among whites. In the 1980s, about 82 per cent of whites were current consumers of alcohol. For coloureds the figure was 41 per cent. In the early twenty-first century, the figures were 60 per cent for whites and 45 per cent for coloureds. ${ }^{31}$ Medical researchers often distinguish abuse from use by referring to high risk or harmful drinking. According to this classification, the prevalence of high risk drinking, especially among farm labourers, is higher in the Western Cape than in the other provinces in the early twenty-first century. ${ }^{32}$ This suggests that coloureds as a group are not necessarily drinkers, but when they drink it is often at dangerous levels.

To some extent, drinking alcohol has become synonymous with coloured farm labourers, as Leila Falletisch argues. This is especially the case for men, who, according to Falletisch, "considered it their right to drink". Although women also drink, there is not the same expectation on them from other farm labourers to drink excessively. ${ }^{33}$ The gender differences in drinking habits can be explained by traditional roles for men and women, wherein women are expected to take care of the household and children, whereas men are considered strange if they do not drink. ${ }^{34}$

The dop system is not the only reason for drinking, though. Falletisch follows in the footsteps of Schärf and brings forth several factors, which contribute to drinking, such as slavery, paternalism and acceptance for drunkenness. These factors have contributed to a situation where the individual farm labourers have been "ab-

\footnotetext{
${ }^{31}$ Rocha-Silva, 1985, p. 16; Shisana et al., 2005, pp. 72-73.

${ }^{32}$ Shisana et al., 2005, pp. 72-73; Gossage et al., 2014.

${ }^{33}$ Falletisch, 2008. pp. 189-90.

${ }^{34}$ Falletisch, 2008, pp. 189-90.
} 
solved of responsibility" for their drinking behaviour. When the individual is seen as having no responsibility, there is also a greater acceptance in the community and in the home. Heavy drinking further leads to violence, unemployment and neglect of the family, for example. And since such behaviour is explained by alcohol use and abuse, the individual is absolved of responsibility again. ${ }^{35}$

The generational impact on alcohol related problems has been central. Heavy drinking is a practice that has been transferred from parents to children and which has generated a pattern wherein heavy drinking is the norm. It has also aided in the reproduction of labour since children of farm labourers themselves become farm labourers and continue to drink heavily. However, while such generational transfers of attitudes exist, they do not alone account for perpetual alcoholism or alcohol related problems. And it is not correct to regard alcohol related problems as static. It is therefore important to note how farm labour has changed through generations and which impact this has had on labourers. Falletisch notes that seasonalization and casualization of labour has contributed to more insecure conditions for labourers, especially women. ${ }^{36}$ However, she disregards the overall transformation of wine farming since the 1970s and its relation to alcohol use and abuse. Continuity and change through generations will therefore be of importance in analysing the role of alcohol in farm labour.

One particular feature of the generational impact on alcohol and farm labour in the Western Cape is Foetal Alcohol Syndrome (FAS). FAS reduces brain development and physical growth in children whose mothers drink heavily during pregnancy. It is one of the most severe effects of alcohol abuse, which contributes to reproduction of labour relations, since it affects children. There is a correlation between FAS and low academic results, which contributes to low social mobility, since it is likely that the children will not be able to find work outside farming. But although the prevalence of FAS is high in the Western Cape, there is no direct relationship between FAS and the dop system. The area with the highest prevalence of FAS is the Northern Cape, where poor housing,

\footnotetext{
${ }^{35}$ Falletisch, 2008, p. 191.

${ }^{36}$ Falletisch, 2008, pp. 58-59, 86, 93.
} 
malnutrition and heavy drinking have been brought forth as explanations. ${ }^{37}$

While the practices on wine farms have contributed to alcohol problems, farmers have also understood the risks involved in abuse. Philip Gossage et al. point out that many farmers in the twenty-first century have taken initiatives "to uplift the lives and working conditions of their workers. [...] These owners are engaging their workers to make working conditions and life on their farms better." ${ }^{38}$ These initiatives to uplift the labour force have rarely been focused in research, and it will therefore be valuable to analyse how they have tied in with the past paternalist practices.

Researchers such as Schärf and Falletisch convincingly deal with the impact of alcohol at the individual and family level and show how abuse concerns not only the drinker, but also family members. While that research has offered much insight into the lives of farm labourers, it has also lacked contextualization of the historical forces, which have created the situation. In this book, I will instead contextualize farming as a changing structure and analyse how farmers have been able to maintain control of their farms and their labour force without a coercive practice. Thereby, it will be possible to see how the new practices have changed conditions for farm labourers and how new demands on labour has altered the role of alcohol.

To be more precise, a central concern of the book will be to find out how the dop system was reduced and how farmers used other methods of labour control to secure labour. By doing so, we can determine how labour relations changed and what role alcohol has played after the disappearance of the dop system. But since alcohol problems have been a central feature of wine farming, I will also focus on what has been done to prevent alcohol abuse by farmers, trade unions, non-governmental organizations (NGOs) and the state. The analysis ends in 2013 when field and archival research was conducted.

The book will be structured mainly chronologically. After relevant perspectives on labour, wine farming and alcohol abuse have

\footnotetext{
${ }^{37}$ See Falletisch, 2008, pp. 69-70; Viall et al., 2011.

${ }^{38}$ Gossage et al., 2014 p. 7420.
} 
been discussed in the first two chapters, the practice of the dop system and its relation to alcohol abuse will be analysed with a focus on the period between the 1940s and the early 1960s in chapter 3 . Thereafter, in chapters 4 and 5, the decreasing role of the dop system will be explained in relation to the changing wine farming practices and social, political and economic conditions during the later half of the twentieth century. This will lead to an analysis in chapter 6 of the labour relations and social conditions for farm labourers after the disappearance of the dop system, which will provide perspectives on the role of alcohol in wine farming in the postapartheid era discussed in chapters 7 and 8 . The book will conclude with a discussion in chapter 9 and contribute with perspectives on how capitalist farming and the role of alcohol have been transformed in the Western Cape since the 1940s.

In addition to material such as journals from farmers' organizations, the Temperance Alliance, census material and select committee and commission reports, interviews with representatives of NGOs, trade unions and the government have been conducted. Two examples of representatives from NGOs are Mercia Andrews from the Trust for Community Outreach and Education (TCOE), and Leana Olivier from the Foundation for Alcohol Related Research (FARR). Both of them have extensive experience of work in wine farming areas with alcohol related problems. Interviews with them are central to understanding not only alcohol problems, but also the work done to prevent them.

During the past few decades, alcohol related problems have also been noticed by the wine industry and by individual farmers. There are several examples of programmes and initiatives, which individual farmers have been involved in, both on their own and in cooperation with NGOs. I will therefore include three such farms in the study, in order to analyse the strategies of farmers, and labour relations on farms, more closely.

The farms are situated in the centre of the wine industry. Two of them, Kanonkop and Beyerskloof, are in Stellenbosch and one, Bosman Family Vineyards, is in Wellington. Kanonkop is owned by the Krige family and Beyerskloof is owned by Beyers Truter, who has owned the farm since 1988. Truter also owns another 
farm, Beyerskloof Vineyards. Bosman Family Vineyards is nowadays made up of three adjacent farms. The core farm has been owned by the Bosman family since 1798 and constitutes one of the most famous vine nurseries in South Africa. In 2007, Bosman resumed production of wine on the farm and since 2008 a part of the farm is co-owned by the Adama Workers Trust.

The selection of these farms is not representative of wine farms in the Western Cape. For one thing, they are all estates, that is, they produce both grapes and wine, whereas most wine farmers only produce grapes and sell to wine producers. Furthermore, they have all actively been involved in so called social upliftment. Conditions on these farms could thus be different than on farms where only grapes are produced and where no social initiatives have been taken. But analysing these farms will also contribute with new perspectives in the debate about alcohol in the Western Cape since the efforts to reduce problems are seldom brought forth. ${ }^{39}$ Examples from these farms will thus demonstrate how the problems related to alcohol have been experienced on farms, how solutions have been found and what the results have been. Interviews were conducted on the farms, where I also interviewed employees. The names of those employed on the farms, who are in a position of dependence, have been altered.

\section{Alcohol and labour in history}

Alcohol has been an important factor in labour relations also in other places and contexts than on Cape wine farms. In nineteenth century England, alcohol created and perpetuated poverty in the working class and thereby upheld the capitalist relations of production. Friedrich Engels noted that

[a]ll possible temptations, all allurements combine to bring the workers to drunkenness. Liquor is almost their only source of pleasure, and all things conspire to make it accessible to them. ${ }^{40}$ The living conditions, and the lack of other social activities for labourers, contributed to the attractive nature of alcohol. To some

\footnotetext{
${ }^{39}$ One example is Human Rights Watch, Aug., 2011, which focuses on social problems, but not how the problems have been handled.

${ }^{40}$ Engels, 2009, p. 133.
} 
extent, at least for men, alcohol was almost as important as more basic means of livelihood such as food and clothing in the reproduction of the labour force:

The working man comes home from his work tired, exhausted, finds his home comfortless, damp, dirty, repulsive; he has urgent need of recreation, he must have something to make work worth his trouble, to make the prospect of the next day endurable. $^{41}$

Surely, food and clothing are the most central means of survival, and thus the most important factors in the reproduction of the labour force, but as Engels noted, the labourer must also have something that makes work worthwhile. When social conditions are poor, and poverty and lack of prospects become overwhelming, it is no surprise that alcohol becomes a means of escape. In the words of Eric Hobsbawm, in the early years of English industrial capitalism, "alcohol was the 'quickest way out of Manchester". ${ }^{42}$ Under those circumstances, alcohol use turned into alcohol abuse.

Before the breakthrough of industrial society, alcohol was often consumed during the working day. But industrial capitalist production meant that the drinking became a problem in production. As Hobsbawm noted, industrial production differed from agriculture where the seasons created a different rhythm. Industrial production implied a division of labour which required strict discipline. Capitalists and managers in factories, and also the state, therefore spent much time trying to change the behaviour of the labourers who were not accustomed to the new conditions. ${ }^{43}$ Members of the working classes in a broader sense, who are self-employed, such as artisans or peasants, do not have to follow such disciplinary rules. E. P. Thompson further clarified how the irregular work rhythm, for example in potteries in the 1830s, was "associated with heavy week-end drinking". The skilled male potters worked under little supervision, which meant that weekend drinking was sometimes extended to Mondays and Tuesdays as well, when they were

\footnotetext{
${ }^{41}$ Engels, 2009, p. 133.

${ }^{42}$ Hobsbawm, 1996, p. 202.

${ }^{43}$ Hobsbawm, 1996, pp. 49-50, 208.
} 
"drinking their earnings of the previous week". ${ }^{44}$ The labourers in industrialized capitalist production cannot follow that example. They have less freedom in the sense that they have less control over their own conditions of work and have few opportunities to change them.

Following Engels, the lack of options for labourers might in itself be a reason for alcohol abuse. There can of course be other reasons, such as personal ones. But in the context of capitalist production we must assume that all such reasons converge in the workplace and will potentially affect how the labourers can perform their work. However, alcohol abuse only becomes a problem for production when it interferes with work. As long as labourers drink on their own time and are sober at work, there should be no reason for complaints from a manager or farmer. In wine farming, there are a number of work operations which require sobriety, especially after machines were introduced. Drunkenness can also lead to carelessness, which can damage both people and vines. But other work operations, such as digging, might not require total sobriety, which explains why drunkenness has not always been seen as a problem by either farmers or labourers.

In southern Africa, alcohol has been closely related to the colonization and subjugation of the indigenous population. Alcohol was used to attract Khoi people into labour on farms during the seventeenth century and as gifts for Khoi leaders. ${ }^{45}$ Labourers became addicted, which made them more inclined to stay on the farms. The alcohol practices used in farming were introduced also in other sectors. During the first decade of mining at the Witwatersrand in the 1880 s, alcohol played an important role in labour recruitment. Migrants from Mozambique apparently had a reputation of having "a taste for strong drink", which was exploited by mine owners, who were cooperating with liquor manufacturers. But during the 1890s there was a stronger opposition towards unrestricted drinking among the black mine labourers. The Temperance Movement was at the forefront of these protests, and was supported by large parts of the white public. The white mine own-

\footnotetext{
${ }^{44}$ Thompson, 1967 , pp. 75-76.

${ }^{45}$ Scully, 1992, pp. 56-57.
} 
ers, on the other hand, opposed calls for prohibition for blacks, arguing that continued alcohol sales to them was necessary for the mine industry. The introduction of deep-level mining caused mine owners to join those who called for limited alcohol sales to blacks, though. Deep-level mining, in comparison with ground-level mining, required more long-term investments, more machinery and a labour force that was more skilled. This, in turn, also required sobriety. ${ }^{46}$ So, mine owners' opinions about alcohol supply to the labour force was changed by transformation of production. They used alcohol to attract labour when this was required, and prohibited it when sobriety was required for intensified capitalist production in the mines.

Alcohol, and especially control over it, has obviously been a central feature in general in the history of labour relations in southern Africa. It can therefore be valuable to also contextualize alcohol use and abuse among the different racial groups in South Africa.

For the blacks of South Africa, alcohol was closely related to festivities and rituals such as harvests, rewards for tribute labour and as tribute to chiefs and other persons of power. Since grain beer was only available to most people during certain periods of the year, they drank much when they had the opportunity. But also intake of relatively small amounts of alcohol was enough to be considered "drunk" in some rural societies in southern Africa. ${ }^{47}$ When European colonizers settled in South Africa and established the Cape Colony, they brought with them their own notions about intoxication, sobriety and abuse. Europeans usually regarded the drinking patterns of blacks from the viewpoint of their own conceptions about alcohol use. They believed that blacks could not handle alcohol as well as Europeans and that blacks drank excessively, especially at their beer parties. ${ }^{48}$

The views held by Europeans were shaped by new discoveries about alcohol during the late nineteenth century. These discoveries included wider knowledge about alcohol as a substance, which was found in various fermented beverages such as wine and beer, and

\footnotetext{
${ }^{46}$ van Onselen, 1982.

${ }^{47}$ Ambler and Crush, 1992, p. 5.

${ }^{48}$ Ambler and Crush, 1992, pp. 6-7.
} 
which was addictive. Thereby, the perception of alcoholic drink as something positive started to change. But in rural societies in southern Africa the notions had not changed. Beer drinking was seen as positive and was an important part of society. ${ }^{49}$ These different views on alcohol are important to consider. While whites regarded alcohol as addictive, they also used and abused it, which means that they did not disapprove of alcohol in itself. The problem was instead the lack of control they had over the drinking of blacks and the perceived lack of order that was related to beer drinking. If whites could control the supply of alcohol, they thought there would be fewer problems caused by it.

During the early twentieth century, liquor regulations for blacks were used to implement labour discipline for industrial work, but also to increase state control and to reinforce segregation. Municipal beer halls, for example, where blacks were allowed to drink, were meant to keep black people in townships also during their leisure time and to spend money there. ${ }^{50}$ The Liquor Act of 1928 was also intended to serve this purpose, since it prohibited sale of "European" alcohol to blacks outside of the allowed areas. But it was not successful; instead of keeping black people sober, it resulted in increased illegal drinking. As Anne Mager demonstrates, shebeens (illicit bars) were valued highly, not least because they were associated with a culture, which whites could not control. The end of prohibition for blacks in 1961 was therefore an attempt to increase government control of the supply of liquor to blacks and to reduce illegal drinking. But shebeens continued to be popular and constituted places of refuge from white control for blacks. ${ }^{51}$ The issues regarding supply of alcohol have consequently been important in South African history. Alcohol in itself has not only been a means to control labourers and create a docile labour force, but also been a means to resist the apartheid system and white domination. In order to understand its role properly, we must therefore insert alcohol into the context of the political economy of wine farming.

\footnotetext{
${ }^{49}$ Ambler and Crush, 1992, pp. 4-5.

${ }^{50}$ Ambler and Crush, 1992, pp. 21-23.

${ }^{51}$ Mager, 2010, pp. 12-15, 27.
} 


\section{THE POLITICAL ECONOMY OF WINE FARMING IN THE WESTERN CAPE}

\section{Race and class on the wine farms}

Wine has been produced in South Africa since the seventeenth century. The first Dutch settlers in the Cape Colony made wine both for their own consumption and for the ships of the Dutch East India Company. The industry developed slowly, though, until the British occupation of the Cape Colony in the early nineteenth century. Wine exports to Britain meant an expansion of the industry, but this lasted only a few decades. The Cape wine was often of poor quality and demand in Europe decreased. ${ }^{52}$

As noted by Williams, slave labour was the foundation of the South African wine industry. ${ }^{53}$ Slaves were brought from other parts of Africa and from Batavia and had a profound impact on rural Western Cape. According to Nigel Worden, slavery created a "class division which coincided with racial differences [...]", which was not seen in urban areas or in the pastoral regions in the eastern parts of the Cape. ${ }^{54}$ The abolition of slavery in the Cape in 1834 consequently affected many wine farmers, who had to find labour through other means. Some of them had problems finding labour, since they could not pay enough wages and the labour issue became a central concern for wine farmers. In that regard, the use of

\footnotetext{
${ }^{52}$ See Olsson, 2018, pp. 29-30.

${ }^{53}$ Williams, 2016, p. 895.

${ }^{54}$ Worden, 1985, p. 138.
} 
wine as wages was a conscious strategy that farmers used to retain their labour force, when they had little opportunity of paying cash wages, and when cash was not always the most important means of exchange. The wine was also desired by the labourers to the extent that they refused to work without it. Farmers obviously had a choice not to give wine, but if they wanted to continue as farmers they had to find labour one way or another. Otherwise they would end up as bywoners, or tenants, on the farms of others. ${ }^{55}$ To some extent, the dop system was thus a remunerative practice, which labourers and farmers could not control. It had become a structure which both farmers and labourers adapted to and which both used to their own advantage.

The abolition of slavery paved the way for capitalist relations based on wage labour. However, as Olsson notes, there were several obstacles to the development of capitalist farming, namely "the making of capital, the making of a commodity market, and the making of a class of labourers". ${ }^{56}$ The obstacle of a sufficient labour supply was especially relevant in the late nineteenth century, and farmers even went beyond the Cape Colony in order to find labour. However, through legislation such as the Glen Grey Act in 1894, aimed at dispossessing black peasants and forcing them into migrant labour, a proletarianized class of labourers emerged, which wine farmers could employ. ${ }^{57}$

During the 1940s, issues of labour supply again emerged as a problem for wine farmers. Nick Vink et al. argue that labour demands in urban industries, and the increased restrictions on migration of black people to the Western Cape, caused a shortage of labour among wine farmers. ${ }^{58}$ Farmers were unable, or unwilling, to pay as high wages as industries in urban areas did. The role of black migrants in the Western Cape during the second half of the century should, however, not be overlooked. In the 1950s, the Coloured labour preference policy was initiated in order to keep blacks from entering the Western Cape and to secure employment

\footnotetext{
${ }^{55}$ See Bundy, 1986.

${ }^{56}$ Olsson, 2018, p. 59.

${ }^{57}$ Olsson, 2018, pp. 52-60.

${ }^{58}$ Vink, et al., 2004, p. 234.
} 
for coloureds. The policy was abandoned in 1984, but already during the 1960s it was outdated, since economic growth created a demand for the labour power of blacks and the state was unable to completely control their migration. ${ }^{59}$ Black labourers have thus been important in the Western Cape, but their position has been different than that of the coloureds. Since they had their home in Bantustans or homelands in other parts of the country during apartheid, they had some access to land, albeit not enough for them to survive on. ${ }^{60}$ But the coloured farm labourers have not had access to land and have become dependent on farmers. They have also adopted the language and culture of Afrikaners, which has brought them closer to the white farmers.

\section{Mechanization and stratification}

During the later half of the twentieth century, South African farming in general went through transformations. Farmers began to mechanize, which was seen in the increasing number of tractors from about forty-eight thousand in 1950 to more than twohundred thousand in $1970 .{ }^{61}$ In wine farming, the most crucial mechanization has been conducted after 1970, though, especially in the form of mechanized irrigation and weeding through pesticides, which has lowered labour demand considerably in those work operations. $^{62}$

In South African farming in general, the introduction of machinery was followed by a transformation of labour relations. According to Tessa Marcus, this could be seen through the increased share of cash wages and the improved training of farm labourers who worked with machinery. Most importantly, this resulted in a stratification of the labour force, where a "core" of permanent labourers remained on farms while others were discarded. ${ }^{63}$ The stratification was based partly on race, which for the Western Cape meant that coloureds were better paid than blacks, and partly on the acquisition of skills among some of the labourers. Those who

\footnotetext{
${ }^{59}$ Humphries, 1989, pp. 169-70, 178-79.

${ }^{60}$ For a discussion on the role of homelands during apartheid, see Wolpe, 1980.

${ }^{61}$ Beinart, 2001, p. 355.

${ }^{62}$ Viall et al., 2011, p. 32.

${ }^{63}$ Marcus, 1989, pp. 1-2, 24-26, 58, 90-91 189.
} 
became tractor drivers or operated other machinery were paid higher wages than the unskilled labourers, although still comparatively low wages. $^{64}$

While Marcus demonstrates that skilled labourers became important, she does not analyse the significance of this process. Schärf, for example, mentions that the lack of skills among farm labourers, what he calls deskilling, along with the dop system, was the basis of labour reproduction in the Western Cape. As farm labourers could not compete with urban labourers, who were more skilled, it was hard for them to leave the farms. The dop system and alcoholism further entrenched their position as rural proletarians, who became dependent on farmers. The introduction of new technology and training for labourers must therefore have impacted not only labour relations, but also the role of alcohol.

Another feature of the transformation of South African farming, which Marcus does not give much attention to, was that the number of farming units decreased during the period and that capital was concentrated in fewer hands. ${ }^{65}$ Not all farmers could thus afford to change production, which means that the transformation not only affected the labour force, but also the farmers. Those who could afford to change production did so, and those who did not were forced to sell their farms, since they could not compete. Thus, the farmers' desire for increased profits and thereby to continue the accumulation of capital must be regarded as the fundamental reason behind the transformation. Transformation and restructuring, should, however, not be regarded as unusual for capitalist production. On the contrary, it is an essential part of it. But only those who are able to transform can compete and continue to accumulate capital in the long-term. Some farmers who are not able to transform production can surely compete for some time, for example with the aid of state support. They can also compete by exploiting their labourers harder and use wine to attract labour, as was done in the Western Cape in the nineteenth century. ${ }^{66}$ However, it is important to consider that accumulation of capital can be fur-

\footnotetext{
${ }^{64}$ Marcus, 1989, pp. 86-87, 116-17.

${ }^{65}$ Marcus, 1989, pp. 7-9.

${ }^{66}$ See Scully, 1990, pp. 55, 64.
} 
thered in different ways. The political situation, for example, can change the conditions for capital accumulation drastically, which must be considered when analysing post-apartheid South Africa. The practices on farms, which generated profits during the midtwentieth century, were perhaps not profitable towards the end of it.

\section{Permanent and seasonal labour in the rural class struggle}

In the post-apartheid era, the number of people involved in wine farming continues to be high. There are some variations in the estimates of the number of employees in wine farming in the 1990s. One figure suggests 45,000 labourers and about 225,000 dependants. Another estimate was 50,000 labourers and 175,000 dependants. At the time, there were about 4,700 producers of wine grapes, which means that there were about 10 labourers per farm, and between 37 and 47 dependants on average per farm. ${ }^{67}$

Wine farming has become more mechanized after 1994, for example in the form of harvest machines, which could replace as many as 70 labourers on a 12 -hour shift. ${ }^{68}$ The introduction of harvest machines, and other machines, has contributed to "externalization and casualization" of labour relations. In the late 1990s, many farmers reduced the number of permanent labourers on their farms. However, according to Joachim Ewert and Andries du Toit, most of these labourers were not replaced by machines. Farmers instead hired labourers on seasonal contracts, either themselves or through labour contractors. Especially women were hired as casual labourers for very low wages. ${ }^{69}$

The increase of seasonal labour has been seen also in Western Cape farming in general. In the late 1990s, the seasonal labourers were both coloured and black, but it was to a greater extent blacks than coloureds who became seasonal labourers. ${ }^{70}$ So, there was a racial divide in the labour force, which meant that coloureds more often were employed in permanent positions. Seasonalization has

\footnotetext{
${ }^{67}$ Farm Labour Review, 1996, p. 207.

${ }^{68}$ Ewert and du Toit, 2005, p. 328.

${ }^{69}$ Ewert and du Toit, 2005, pp. 327-28.

${ }^{70}$ Farm Labour Review, 1996, p. 35.
} 
meant that labourers have lost houses and other benefits, which are only provided by farmers to permanent labourers. Farmers thus take less social responsibility, which implies that the remaining paternalist structure on farms only involves a part of the labour force. ${ }^{71}$ According to Human Rights Watch in 2011, evictions from farms were commonplace in the wine farming areas, and constituted one of the most severe problems for the rural working class. ${ }^{72}$ In the twenty-first century, the paternalist practices, which meant that the farm labourers were part of the farm, did not apply to the same extent as previously. The labourers were the ones to suffer most from this as the effects of the dop system did not disappear. Or rather, the effects were even more evident when the paternalist structure was weakened.

While farmers have had the upper hand in the rural class struggle, it is important to note that labourers have not been passive. In recent years, trade unions have become more influential in farming areas of the Western Cape. In 2008, strikes began in De Doorns in the Western Cape and in 2012 and 2013 large scale strikes took place in many regions of the Western Cape. The strikes were spontaneous at first, but Nosey Pieterse from Bawsi and Allied Workers Union of South Africa (BAWUSA) and Tony Ehrenreich from the Congress of South African Trade Unions (COSATU) assumed leadership. ${ }^{73}$ Another trade union that is active in the wine regions is The Commercial Stevedoring and Allied Workers Union (CSAAWU), which is not affiliated with COSATU. Also Sikhula Sonke, which is usually described as a social movement rather than a union, has gained support and members in the Western Cape.

But while trade unions are relative newcomers in wine farming, NGOs have been involved since at least the 1980s with issues such as labour relations, social conditions and alcohol abuse. The Rural Foundation was the first organization that actively tried to improve conditions on farms in the Western Cape during the 1980s. It was jointly funded by the state and organized agriculture. Its work included social problems, housing and alcohol related problems. In

\footnotetext{
${ }^{71}$ Ewert and du Toit, 2005, pp. 327-28.

${ }^{72}$ Human Rights Watch, Aug., 2011.

${ }^{73}$ For discussion on the impact of the strike, see Ntsebeza, 2013 and Eriksson, 2017.
} 
the post-apartheid era, several NGOs have been involved in improving social conditions in rural areas. For example, Dopstop has been involved with opposing the dop system, The Trust for Community Outreach and Education (TCOE) has dealt with land rights and labour relations and Women on Farms have focused on women's rights on farms.

\section{State control and estate revolt}

The wine farmers were intricately involved in the formation of the Afrikaner nationalist movement in the early twentieth century and constituted one of the National Party's most important groups of supporters during apartheid. ${ }^{74}$ But already before that, wine farmers were supported by the state. This was most notably seen through the creation of the Koöperatieve Wijnbouwers Vereniging (KWV) in 1918 to deal with the problem of overproduction and to reduce the wine producers' exploitation of farmers. Further legislation increased the role of the KWV and it was given monopoly on wine export and import and controlled production quotas and what sort of vines that were to be planted. In 1940, the Wine and Spirit Control Act even stipulated that any wine production in South Africa required permission from the KWV. The act further gave the KWV the power to "set an annual minimum price for 'good wine' and for 'quality wine' of which wholesalers had to buy a minimum percentage". Thereby the KWV increased its control over the wine industry and was able to set prices "for distilling good and quality wines, protected its effective monopoly of the export market and secured, in principle, powers to limit production". In 1970, the "KWV Act" reinforced earlier legislation and also strengthened the relationship between the KWV and the National Party. $^{75}$

Wine production was deregulated in the early 1990s and the quota system was abolished in 1997. That generated an increased production, from 50 million litres in the 1990s to 395 million litres in 2009. Almost 50 per cent of the wine is now exported. The deregulation, however, also caused many farmers to succumb, since

\footnotetext{
${ }^{74}$ See Schärf, 1984, p. 211; Nugent, 2011, pp. 343, 359, 362.

${ }^{75}$ Vink et al., 2004, pp. 233, 235.
} 
competition, especially on the international market, became harder. ${ }^{76}$ Although mechanization has affected labour relations after 1994, Ewert and du Toit emphasize the restructuring of the wine industry and the wine market as the most crucial change. This restructuring has meant increasing competition, less state support for farmers and more state interference regarding for example wage levels. ${ }^{77}$

It is important to note that the deregulation of the wine industry was not initiated by the ANC government, but by the National Party during its last years in power. As Ewert argues, the deregulation might have been an attempt by white capital owners to prevent the ANC from gaining control over the wine industry after a future takeover of power. ${ }^{78}$

A transformation of the regulated wine industry had, however, begun long before the 1990s. Already in the 1970s, the KWV's monopoly and control over the industry had been questioned by some farmers. The farmers were concerned that the regulations set by the KWV impeded their production and thereby their ability to accumulate capital. An increasing number of farmers therefore began producing their own wine independently from the KWV. These were known as estate wines, meaning that both production of grapes and production and bottling of wine was conducted on the farm. There had been estates in the Western Cape before the 1970 s, but they were few and not famous to the public "unless, like some of the Constantia farms, they were widely known by repute". ${ }^{79}$ The farms in Constantia outside Cape Town were the first wine farms in the country. The most famous one, Groot Constantia, was founded in the seventeenth century by Simon van der Stel. The Constantia farms were large, but quite few, and produced quality wine, which was famous in many parts of the world. ${ }^{80} \mathrm{Un}$ til the 1970 s, most of the quality wine in South Africa was produced there.

\footnotetext{
${ }^{76}$ Viall et al., 2011, pp. 19, 92, 94, 96-97.

${ }^{77}$ Ewert, and du Toit, 2005, pp. 327-28.

${ }^{78}$ Ewert, 2012, p. 227.

${ }^{79}$ Wynboer, Jan., 1975, pp. 91-93.

${ }^{80}$ Viall et al., 2011, pp. 37, 40, 42-43.
} 
The estate farmers planted the vines that they wanted, and produced their own wine on the farm. These estate wines, with a reputation of high quality, became more popular in the 1980s. In 1980, the six premium cultivars Chardonnay, Sauvignon Blanc, Cabernet Sauvignon, Merlot, Pinotage and Shiraz constituted 6.5 per cent of the vineyards in South Africa. In 1990, the use of those cultivars had almost doubled as they made up 12.5 per cent of the vineyards, and in 1995 they constituted 19 per cent. ${ }^{81}$ After the 1970s, more high quality wine has thus been produced. More and more farmers have tried to sell in the upper levels of the market, but not all have managed to do so, and others have not been interested. Those farmers who have delivered to co-operatives or private cellars that produce the wine must therefore be differentiated from the estate farmers, who have produced their own wine under their own label.

The estate farmers are the ones who have wine tastings, and therefore have an interest in tourism as it contributes to their income. The co-operative farmers do not depend on tourism; instead they deliver their grapes to co-operatives or private cellars, and thereby do not have to concern themselves with production, marketing and sales of wine. In 2002, there were 83 estates in South Africa that produced their own wine. In comparison there were 66 co-operatives that produced wine. There were also 266 private cellars that were not estates. ${ }^{82}$ An absolute majority of farmers thus delivered their grapes to co-operatives or private cellars in the early twenty-first century.

The distinction between estates and co-operative farmers demonstrates that there have been different sorts of wine farms where farmers have used different methods for making profits. The estate farmers have produced grapes and wine and bottled it under their own label, while co-operative farmers have produced grapes and sold them to co-operatives or private cellars for production of wine and for bottling. The estate farmers have thus had an interest in improving the quality of grapes and wine, experimenting with different grapes and methods of farming, while co-operative farmers

\footnotetext{
${ }^{81}$ Vink et al., 2004, p. 237.

${ }^{82}$ Vink et al., 2004, p. 242.
} 
have relied on selling large quantities of grapes in order to secure the largest possible income. The production of better quality wine on estates meant investments in the farms, for example in vines, chemicals and machinery. The impact of these improvements on the labour relations on farms is, however, uncertain. There are several researchers who argue that conditions for labourers, and to some extent labour relations as well, changed during the late 1970s and early 1980s. For example, housing for farm labourers was improved, and social activities were encouraged. Farm labourers also became more involved in the management of the farm through farm labour committees on farms. ${ }^{83}$ But it is more uncertain how the labour relations and the remunerative practices changed in relation to the new production. The dop system was clearly important also during the 1980s and 1990s, but perhaps for different reasons and in different areas than it had been before.

\section{Legislation}

In order to evaluate the practice of the dop system and its disappearance, we must first know how it has been regulated. It is usually stated that the dop system was abolished in $1963 .{ }^{84}$ This is true in the sense that the section in the 1928 Liquor Act, which allowed Cape farmers to provide alcohol to labourers, was removed from the Act in 1963. The Act of 1928 did, however, not allow wine or any liquor to be given as wages or part of wages. It only stipulated that wine or liquor could be given "gratis". Thus, as Schärf and Falletisch argues, the wine was often given as a supplement, or a bonus in addition to the cash wage, the rations of food and housing to labourers and farmers considered the tot as a gift to those who did favours, which they did not consider as labour. ${ }^{85}$ The Act of 1928 can therefore not be used to argue, as Paul Nugent does, that the dop system, defined as a system wherein wine was given as wages, was regulated or limited. ${ }^{86}$ The Liquor Act of 1928 clearly stipulated that no wine could be given as wages or part of wages,

\footnotetext{
${ }^{83}$ Mayson, 1990, pp. 177-88; du Toit, 1993, p. 317.

${ }^{84}$ See for example Schärf, 1984, p. 150; Falletisch, 2008, p. 56, argues 1961 referencing de Kock.

${ }^{85}$ Schärf, 1984, p. 154; Falletisch, 2008, p. 56.

${ }^{86}$ See Nugent, 2011, p. 354.
} 
but farmers in the Cape Province were allowed to give up to one and a half pint of unfortified wine or kaffir beer to black, coloured and Asian employees "gratis" per day if they were 21 years or older. ${ }^{87}$ The legislation considered the Cape separately from the rest of the country, since the dop system had been used there.

But giving liquor as wages was not allowed even before 1928 . Proclamation 14 of 1809 clearly stated that "no Wine, Brandy, or other spirituous Liquors, shall be considered as necessaries of Life, and consequently no allowance shall be made for the supply thereof to a Hottentot by his Master during the period of his employment". ${ }^{88}$ Obviously, farmers did not follow that proclamation since the dop system continued. But it is important to emphasize that giving wine as wages has not been allowed since 1809 and that its continuation was in fact more due to the inability of the state to enforce laws and proclamations than to legislation that allowed it. The state has thus not endorsed the giving of wine as wages, but clearly failed to enforce the laws.

While the Liquor Amendment Act of 1963 meant that the dop system could not be used in any way, it was not forbidden to give wine for free. Therefore, it can be argued that the dop system continued as it had before, since it was illegal to give wine as wages also before 1963. The 1977 Liquor Act once again reinforced that it was illegal to use wine as wages, which can only mean that such a practice was still common, and that it was regarded as a problem. Farmers could still give wine for free, but it is possible that they also had started to sell wine to labourers. The 1977 Liquor Act stipulated that "[t]he quantity of liquor which may be sold or supplied by the holder of a wine farmer's license [...] shall not be less than 9 litres in a receptacle or receptacles properly and securely sealed". ${ }^{89}$ The 9 litres can be regarded as a weekly ration, especially if we compare it with the 1.4 litres per day, or 9.8 litres per week, given under the dop system.

\footnotetext{
${ }^{87}$ Statutes of the Union of South Africa. Liquor Act 1928 (No. 30 of 1928).

${ }^{88}$ The Cape Town Gazette and African Advertiser, Nov. 4, 1809. Proclamation 14 of 1809, Caledon, Nov. 1, 1809; See also Williams, 2016, pp. 899-900.

${ }^{89}$ Statutes of the Republic of South Africa. Liquor Act 1977 (No. 87 of 1977).
} 
After 1994 and the transition to democracy, the alcohol legislation was again changed. The Liquor Act of 2003 stipulated that an employer in the liquor industry was not allowed to supply liquor "to any person as inducement to employment" or "as or in lieu of wages or remuneration" or "deduct from an employees' wages or remuneration any amount relating to the cost of liquor or methylated spirits", which was "supplied to the employee or to a person on behalf of the employee" or "purchased by or on behalf of the employee". ${ }^{90}$ This clearly reinforced the legislation regarding liquor as wages. We should thus assume that it still occurred in some form, since there would have been little reason to ban a practice that did not exist. It was, however, still allowed for farmers to give wine for free.

The legislative measures taken during the period from the 1960s to the early twenty-first century indicate that the various governments recognised that there was a problem with the giving of wine or liquor as wages. But there was no ambition to uphold the law. During the twentieth century, no person was sentenced under the Liquor Act for supplying wine to labourers. ${ }^{91}$ Legislation and practices on farms were obviously two different things.

\footnotetext{
${ }^{90}$ Statutes of the Republic of South Africa. Liquor Act 2003 (No. 59 of 2003).

${ }^{91}$ Falletisch, 2008, p. 56.
} 


\section{THE DOP SYSTEM AND DRUNKENNESS IN THE CAPE - 1940S TO $1960 \mathrm{~S}$}

\section{The dop system in practice}

During the period around the Second World War, the dop system was an integral part of labour relations on wine farms, and on other farms, in the Western Cape. It had been so for hundreds of years. The 1928 Liquor Act had regulated the amount of alcohol farmers were allowed to give to the labourers "gratis", which was one and a half pint per day. Before that the farmers themselves were the ones who decided the amount of wine to be given, and according to the Meaker commission in 1945, it seems that two bottles at least were "frequently given" to coloured labourers. ${ }^{92}$ The 1928 Act stipulated that it was not allowed to give liquor in any form as wages, not even in the Cape. From the farmers' point of view they might not have given wine as wage, only as an addition to it. The KWV mentioned that farmers gave tots of wine to the labourers, since they expected it and thought that it was their right to receive wine. This was also one of the strongest arguments used by defenders of the dop system. If other farmers could give their labourers part of the produce on the farm, such as sheep, cattle or grain, then wine farmers should also be allowed to give part of their product, wine. The KWV even called it "inhuman", if a labourer on a wine farm was not expected to "consume the product

\footnotetext{
${ }^{92}$ Report of the Cape Coloured Liquor Commission of Enquiry, 1945 (Meaker commission), p. 10.
} 
which he himself helps to produce"..$^{93}$ Most wine farmers did, however, not manufacture their own wine, only the grapes, and were forced to acquire it from outside the farm. The KWV manufactured

an excellent unfortified light wine for this purpose, from grapes pressed in its cellars, which is then supplied to its members for this purpose. ${ }^{94}$

Production and distribution of dop wine for most farmers was thus taken care of by the KWV.

There were some variations in the practice of using the dop system, though. Some farmers, mainly the wine farmers, gave the maximum amount at five times during the day all year round. Others gave less than the maximum amount throughout the year and others gave less than the maximum amount but only at certain times during the year when hard work was required. On the farms where the dop system was used only seasonally, the wine was mainly used to attract additional labour. Although the tots were usually given during workdays, the Meaker commission indicated in 1945 that wine was also given on Saturdays and Sundays, but it was hardly likely to be the full amount. ${ }^{95}$

On the wine farms it was common that farmers gave the first tot already in the morning before work started. Thereafter it was given at breakfast, teabreak, at lunchtime, in the afternoon and after work. It was thus administered perhaps six times during the day, with a few hours in between. ${ }^{96}$ That interval meant that labourers were almost constantly under the influence of alcohol and even though they were not drunk at work, they were not sober either. The strength of "boerwyn", that is, the wine used for tots, was 12 per cent alcohol per volume. During a day, a labourer was allowed to be given one and a half pints of wine. Each tot was about 170.4 $\mathrm{cc}$, which meant $852 \mathrm{cc}$ of wine per day. It was estimated that the alcohol in each tot would take about two hours to leave the

\footnotetext{
${ }^{93}$ Report of the Select Committee on the Subject of the Liquor Bill, 1952, H. F. Theron, KWV, p. 302.

${ }^{94}$ Select Committee on the Subject of the Liquor Bill, 1952, KWV, p. 285.

${ }^{95}$ Cape Coloured Liquor Commission, 1945, pp. 11-12.

${ }^{96}$ See Schärf, 1984, p. 153.
} 
body. ${ }^{97}$ The Meaker commission thus argued that the farm labourers who were given alcohol were "under the influence of alcohol most of the day" and worked "in a dazed state". ${ }^{98}$

It is difficult to state the exact number of people who were affected by the dop system, but there are some approximations. In 1945, the Meaker commission estimated that there were between thirteen thousand and fifteen thousand farm labourers under the dop system. The KWV estimated them to be as many as twenty thousand. ${ }^{99}$ It has not been possible to establish the number of labourers on wine farms, but in 1955 there were 95,473 coloured farm labourers in the entire Cape Province. ${ }^{100}$ It is thus clear that only a minority of the coloured farm labourers, who dominated in the Western Cape, were involved in the system. The estimates are, however, misleading, since the dop system affected more than those who were given wine, for example family members of labourers.

Although farmers argued that they gave wine for free to the labourers, the dop system was considered as part of the remuneration, both by farmers and labourers. We know this because there were farmers who had stopped using the dop system, and instead paid higher cash wages. Consequently, the wine must have been regarded as a commodity with value, which could be replaced by another commodity, money. We can even determine the value of the tot. In 1952, J. B. le Roux, a wine farmer in the Western Cape, noted that the wine produced for labourers cost about $3 \mathrm{~d}$. per day per labourer. ${ }^{101}$ But it appears to have been worth more than that. The regular wage for farm labour in the early 1950s was $3 \mathrm{~s} .6 \mathrm{~d}$. per day. Farmers who had stopped using the dop system instead paid $5 \mathrm{~s}$. and had no problems finding labour, although there were some labourers who refused even 6s. per day. ${ }^{102}$ Thereby, it is evident that the tots had value to both farmers and labourers, which

\footnotetext{
${ }^{97}$ Cape Coloured Liquor Commission, 1945, p. 12.

${ }^{98}$ Cape Coloured Liquor Commission, 1945, p. 13.

${ }^{99}$ Cape Coloured Liquor Commission, 1945, p. 11.

${ }^{100}$ Agricultural census 1954-1955, p. 36.

${ }^{101}$ Select Committee on the Subject of the Liquor Bill, 1952, J. B. le Roux, Agricultural Union of the Winter Rainfall Area, p. 344.

${ }^{102}$ Select Committee on the Subject of the Liquor Bill, 1952, A. G. Long, Temperance Alliance, p. 328, A. J. H. Burger, Agricultural Union of the South-Western Districts, p. 341.
} 
could be replaced by other forms of remuneration, and that the value per day was $1 \mathrm{~s}$. $6 \mathrm{~d}$. at the very least and even $2 \mathrm{~s}$. $6 \mathrm{~d}$. in some cases. Since the production cost for the wine was only $3 \mathrm{~d}$. per day, it is not surprising that many wine farmers wanted to continue using the dop system. In the 1950s, as had been the case previously, giving wine was a way to keep wages down.

But also labourers were responsible for the reproduction of the system. The existence of the dop system even affected farmers and labourers in areas where it was not used. Rev. de Beer from the Dutch Reformed Church argued that he had met farmers, who were not wine farmers, who had told him that "their servants practically insist on also getting their tot". ${ }^{103}$ Farmers in areas where the dop system was not used had apparently asked if they could acquire some of the "pure light wine" to use for tots. Those farmers had noticed that the labourers wanted liquor and that after a few days of work when they had earned some money they did not come to work for days, because they went to "look for liquor." Also white labourers did this. Co-operatives in those areas had apparently considered if they could create storages from where farmers could buy liquor for the labourers. ${ }^{104}$ So, there were those who could profit from the practice of giving wine, since not all farmers, not even most grape producers, produced wine themselves. This also clearly shows a distinction between the dop system and other forms of wages in kind such as meat or maize, which was supplied directly from the farm and not from co-operatives.

Since it was profitable to sell wine to farmers, the KWV was interested in extending the dop system to other provinces. H. F. Theron explained that he "would very much like to see that, since it will create a more extended market for the product I produce". ${ }^{105}$ The abolition of the dop system would, however, not make much of a difference to the wine industry. W. J. Pretorius referred to the Meaker Commission, which stated that the amount consumed under the dop system was 7,000 leaguers per year out of 500,000 leaguers

\footnotetext{
${ }^{103}$ Select Committee on the Subject of the Liquor Bill, 1952, Rev. D. F. B. de Beer, Dutch Reformed Church, p. 68.

${ }^{104}$ Select Committee on the Subject of the Liquor Bill, 1952, A. J. H. Burger, Agricultural Union of the South-Western Districts, p. 338.

${ }^{105}$ Select Committee on the Subject of the Liquor Bill, 1952, H. F. Theron, KWV, p. 307.
} 
produced. But he thought that abolition of the system would be detrimental to the economic structure of the wine industry. ${ }^{106}$

The wine farmers, represented by the KWV, held the view that the dop system was not harmful. In fact, the KWV argued that the "farm labourers receiving the tot are generally a very sober class". ${ }^{107}$ Instead, they shifted the focus to other problems, which would arise if the system was abolished, for example, that it would generate illegal wine making on the farms. ${ }^{108}$ The dop system thus improved the labour relations on farms, according to farmers, especially since the labourers would be discontent if they did not get their wine. If labourers did not get the tot, they would acquire liquor in other places. There was a risk that they would make their own wine, which was regarded as a "disadvantage" both to the health of labourers and to farmers' possibility of acquiring labour. Instead, the KWV claimed that "[a]ll farmers know that it is to their advantage to give their labourers good, light wine". ${ }^{109}$ The view of farmers and the KWV was thus that the dop system did not lead to alcohol abuse, that it was not harmful and that it did not affect the health of the labourers negatively.

Some witnesses to the Meaker commission argued that labourers under the age of 21 were given wine on farms. In some cases labourers stated the wrong age when hired, and thus tried to convince the farmer that they were at least 21 years old. But farmers were also not eager to control the age of labourers, and did not always "feel constrained to be over-careful to wait until the youth is exactly twenty-one years old" to give wine. ${ }^{110}$ Farmers did thus not seem to care if they gave wine to labourers who were not old enough. They probably knew that breaking the law would not render punishment. Schärf, for example, did not find any court cases where farmers were accused of giving wine to children under the age of sixteen, although he had heard many rumours of such practices. $^{111}$

\footnotetext{
${ }^{106}$ Select Committee on the Subject of the Liquor Bill, 1952, W. J. Pretorius, KWV, p. 311.

${ }^{107}$ Select Committee on the Subject of the Liquor Bill, 1952, KWV, p. 285.

${ }^{108}$ Select Committee on the Subject of the Liquor Bill, 1952, KWV, p. 299.

${ }^{109}$ Select Committee on the Subject of the Liquor Bill, 1952, KWV, p. 302.

${ }^{110}$ Cape Coloured Liquor Commission, 1945, p. 5.

${ }^{111}$ Schärf, 1984, p. 154.
} 


\section{Opposition to the dop system}

Despite the widespread use of the dop system, there were also those who opposed it. The Temperance Alliance and various churches had criticised the system since the turn of the century 1900. Several commissions had also investigated the issue since 1918 and recommended regulation or abolition of the dop system. ${ }^{112}$ In that regard, there was an opposition to the system, but it was hard to change practices on the farms. During the 1930s and 1940s, the drinking habits of the coloured population received much attention. The Meaker commission stated in 1945 that there was a "rising tide of drunkenness during the war years". ${ }^{113}$ The public expressed concern about the problem with drunkenness and judges noted that an increasing number of crimes were caused by drunkenness. But also farmers in the Western Cape discussed the issue and the Dutch Reformed Church was concerned and also passed resolutions regarding drunkenness. ${ }^{114}$

The appointment of committees to investigate the issue of drunkenness indicates that it was perceived as a problem by the state. The number of convictions for drunkenness in the Cape rose from 14,481 in 1938 to 21,634 in 1944. Those figures did not reveal if the offenders were living in urban or rural areas. However, of the inland areas, the public drunkenness appeared "to be worse in the wine producing districts". ${ }^{115}$ In wine districts such as Stellenbosch, Robertson and Paarl this trend was definitely seen. In Stellenbosch the number had risen from 184 in 1938 to 383 in 1944, in Robertson from 246 to 451, and in Paarl from 431 to 580. However, the opposite trend was also visible, for example in Worcester, where the number of convictions for drunkenness had decreased from 613 in 1938 to 506 in 1944. Some rural districts were thus not affected as much as others. But drunkenness was not only a rural phenomenon. In Cape Town, the number of convictions had risen from 3,501 in 1938 to 5,553 in $1944 .{ }^{116}$ Drunkenness also increased at the national level during and immediately af-

\footnotetext{
${ }^{112}$ See Nugent, 2011, pp. 349, 356.

${ }^{113}$ Cape Coloured Liquor Commission, 1945, p. 6.

${ }^{114}$ Cape Coloured Liquor Commission, 1945. p. 5.

${ }^{115}$ Cape Coloured Liquor Commission, 1945, p. 7.

${ }^{116}$ Cape Coloured Liquor Commission, 1945, Appendix A.
} 
ter the Second World War. Between 1943 and 1947 the number of convictions under the Liquor Laws increased from 175,740 to $208,910 .{ }^{117}$ While this trend was visible in all racial groups, the highest increase was seen among whites. There were, however, few who regarded this as a problem at the time.

The Temperance Alliance and the Dutch Reformed Church were two of the strongest opponents of the dop system and drunkenness in general. The Temperance Alliance, for example, published a pamphlet in 1939 criticising the system and suggested that the coloured farm labourers in the Western Cape were "never perfectly sober". ${ }^{118}$ But representatives of the Temperance Alliance also visited some of the large wine farming areas in the Western Cape such as Stellenbosch, Paarl, Worcester, Robertson, Montagu and Wellington in order to gain support for "the total abolition of the tot". ${ }^{119}$ It seems as if the Temperance Alliance was not successful in its attempt to gain support, though. Wine and Spirit, the wine farmers' journal, argued that the pamphlet was a "misdirected attack launched upon the Tot system [...]", and reported that the reactions from the meetings were the same everywhere, namely that people had protested against the "quite unfounded allegations levelled at the winegrowers" by the Temperance Alliance. Farmers and other whites in wine regions did thus not regard the dop system as the cause of alcoholism and social problems among coloured labourers. Wine and Spirit agreed and further explained that wine farmers could not be regarded as the cause of "degeneracy" of many coloureds, since the largest problems were not found on the farms, but in towns. Crime and drunkenness was just as common in towns as in the countryside during weekends even though "the town degenerates have never perhaps seen a farm, let alone been 'slaves of the tot system'". Therefore, the Temperance Alliance was wrong in their "onslaught upon the tot as the arch enemy of sobriety".

\footnotetext{
${ }^{117}$ Select Committee on the Subject of the Liquor Bill, 1952, A. G. Long, Temperance Alliance, p. 92.

${ }^{118}$ Wine and Spirit, May, 1939.

${ }^{119}$ Wine and Spirit, May, 1939.
} 
But Wine and Spirit even called the dop system "harmless" and claimed that the Temperance Alliance could not find drunk labourers on farms. One farmer in Worcester was certainly convinced of the harmless nature of the dop system. It appears that he practiced it himself. He even challenged the Temperance Alliance to visit his farm together with a doctor and "find a labourer under the influence of alcohol. If you do, you can have one of my farms as a gift". Wine and Spirit of course supported the farmer and explained that such a labourer could not be found since the "farmer knows his own job", and more importantly, the farmer would not allow drunkenness to "rob him of efficient service from his employees". ${ }^{120}$ The productivity argument was often referred to by the supporters of the dop system. For example, farmers argued that tots of wine during the day actually increased the productivity of the labourers and that they worked better, had more energy and strength from drinking wine. And since they worked hard in the fields they sweated out the alcohol from their bodies. ${ }^{121}$ The Temperance Alliance and opponents of the dop system on the other hand referred to studies which showed that alcohol did not increase the productivity, and that it was even unhealthy to work and drink wine during the day. ${ }^{122}$

However, Wine and Spirit went further in the attempt to convince readers that farmers were not responsible for alcoholism among labourers. And they blamed legislation and the lack of enforcement of the laws, which made labourers "constantly exposed to the temptation of the shebeen or of unlimited purchases from canteens". Shebeens, illegal liquor outlets, were commonplace in the Cape, both in urban and rural areas. These were often run by women who used the liquor sales as additional income for the family. Although the farmers gave wine to their labourers, Wine and Spirit argued that the farmer's "efforts to keep his men temperate and sober are perpetually endangered by the misuse and mis-sale of semi-poisonous drink elsewhere". The labour practices were thus not the cause of alcoholism or heavy drinking, according to the

\footnotetext{
${ }^{120}$ Wine and Spirit, May, 1939.

${ }^{121}$ See Cape Coloured Liquor Commission, 1945.

${ }^{122}$ See Cape Coloured Liquor Commission, 1945.
} 
farmers. Surely, some farmers were interested in keeping the labourers sober, but with the dop system such an aim seems to have been difficult to reach. However, the farmers did not want drunkenness among the labourers, since that would harm productivity. It is therefore possible that the dop system did not cause drunkenness, at least not on a large scale, during working hours.

The demand of the Temperance Alliance to abolish the dop system was certainly based on its wish to reduce drunkenness. But its concerns also revealed that it thought that the labourers who were involved did not know what was best for them, which suggests that racism and notions of underdevelopment formed the opinions of the Temperance Alliance. In 1952, A. G. Long from the Temperance Alliance explained that until the "various backward races reach a sufficient stage of development to be enabled to look after themselves properly, legislation is necessary to protect such people from themselves". However, those who had become "fully civilized and educated to European standard" should be treated differently. ${ }^{123}$ In this regard, the view of the Temperance Alliance was clearly not much different from that of the farmers, who also wanted to protect their labourers. The difference was of course that farmers thought that the towns, and the shebeens, were the main problems, and that the dop system was a way to keep labourers away from them. Still, the debate about the dop system was carried out by others than the coloured labourers, and both sides argued that they were protecting the interest of the labourers. Paternalism was clearly not just something that characterized relations on farms, but existed in various parts of society in matters concerning the group of coloureds.

In addition to the Temperance Alliance, the South African Medical Society for Combating Alcohol challenged the dop system. The Medical Society called for the abolition of the dop system as one of the most important measures in order to combat alcohol dependency. The Medical Society used scientific and medical arguments. For example, farmers and other defenders of the system said that the purpose of the dop system was to "produce better work" since

${ }^{123}$ Select Committee on the Subject of the Liquor Bill, 1952, A. G. Long, Temperance Alliance, p. 325 . 
alcohol was a "stimulant". But the Medical Society argued that it had "been shown repeatedly" in scientific studies that alcohol as a stimulant in work was "physiologically unsound". Instead of improving strength and productivity, the perpetual use of alcohol "finally undermines strength and morale". The money which was used to provide wine to labourers "would produce better results if used to provide good food, clothes and housing". ${ }^{124}$ The same arguments were made by the Meaker commission in 1945 and it was thus well-known that alcohol did not improve productivity. Farmers did, however, still maintain that the tot was good for the labourers, or at least better than uncontrolled drinking in shebeens or in bars in towns. Labour and leisure clearly constituted an important contrast for farmers, who knew that they could control supply of alcohol on the farm, but not outside of it. Labourers who drank outside of the farm were also outside the control of farmers.

In 1950, the judge-president of the Cape Division of the Supreme Court, Justice J. E. de Villiers, argued strongly against the dop system. He had delivered judgement in a case in Worcester, where five coloured men, who were apparently farm labourers, were charged with murder. Farmers who testified in the case stated that "at least four substantial tots were provided each working day [...]" to the labourers. De Villiers noted that "the tot system, combined with week-end excursions to the canteens, had the effect that a large number of the Coloured farm labourers of the district were regularly under the influence of liquor to a greater or lesser degree". The dop system in combination with visits to bars and canteens in towns was thus again recognized as the main problem. According to de Villiers, more than eighty per cent of crimes he dealt with occurred between Friday afternoon and Sunday evening. Friday was pay-day, which meant that labourers went to spend their money on alcohol. They continued doing so also on Saturdays and Sundays. It was during the weekend that the labourers drank excessively, during the working week they had less opportunity to do so. It was the excessive drinking that caused crime, and this was especially prevalent in the wine districts; de Villiers thought it was obvious

${ }^{124}$ The Temperance Bulletin, March, 1950. 
that the "underlying cause of much of the serious crime in this district, as well as in other wine-producing districts, is the overindulgence on the part of these people in liquor". ${ }^{125}$ Such criticism from a judge-president definitely indicates that the dop system and social conditions on farms in the wine producing areas were not supported by the judicial elite.

\section{Causes and effects of drunkenness}

While critics of the dop system were eager to point out that the practices on farms directly caused alcoholism, there were also other explanations. The Meaker commission of 1945 investigated reasons for drunkenness from several viewpoints and it is relevant to look more closely at them. The commission noted that it was not possible to "isolate the questions of drunkenness from the many allied major problems of poverty, health, housing, education, crime, etc." The relationship between the various problems was not easy to analyse, since there was no "clear dividing line", which could be drawn between causes and effects of drunkenness. The causes and effects overlapped, and often the "same set of conditions" was both cause and effect. Therefore, any change of the situation required that those conditions were given attention. ${ }^{126}$

The dop system was regarded as one cause for drunkenness by the Meaker commission. Some witnesses stated that it was "next to impossible for farm labourers to drink wine regularly from Monday to Friday and then not drink on Saturday when they visit the town, or on Sunday when they do not work". ${ }^{127}$ The wine on the farms was unfortified and thereby less intoxicating than the fortified wine sold in for example bars or bottle stores. When the labourers came to town and drank the fortified wine, in "larger quantities than is usual on the farm", they became "completely drunk", and they often had to spend some days in prison. ${ }^{128}$ The main problems with the dop system were thus not so often seen on the farms during the working week, but in the towns and in bars,

\footnotetext{
${ }^{125}$ The Temperance Bulletin, Dec., 1950.

${ }^{126}$ Cape Coloured Liquor Commission, 1945, p. 2.

${ }^{127}$ Cape Coloured Liquor Commission, 1945, p. 5.

${ }^{128}$ Cape Coloured Liquor Commission, 1945, p. 5.
} 
canteens and shebeens during weekends, when the labourers were not working. But the system itself was also criticised by the commission. The system was "said to lend itself to abuse [...]", since farmers had the wine on their farms and could "easily reward additional work with an extra tot". This was the customary way and the labourers did not seem to object to that practice. This of course implies that the legal number of tots was not regarded as a severe problem. The system was even more dangerous when it involved young people. According to witnesses, boys under the age of 21 were given tots in some instances, although we do not know how often it occurred. When the wine was of inferior quality it was even more harmful. In all, the committee argued that "this state of affairs must and does increase drunkenness". ${ }^{129}$

The position of the churches was similar. The Reverend D. F. B. de Beers, the secretary of the Federal Council of the Dutch Reformed Churches of South Africa, explained that "[a]lthough the object in introducing the tot was originally a good one - inter alia, to keep the Coloured person away from the bar - the effect was different". ${ }^{130}$ Instead of reducing alcohol consumption, it "created the appetite for stronger liquor". He said that, according to missionary preachers, the dop system had become the "training-school for inebriety". ${ }^{131}$ The Dutch Reformed Church was clearly not opposed to the establishment of the dop system in itself, if it kept people from buying liquor elsewhere. But de Beers and the missionaries he referred to had thus changed their minds, and regarded the system as a direct cause of alcohol abuse.

Other factors were, however, of importance. The witnesses to the commission were in agreement that "unsatisfactory social conditions" was a main reason behind increased drinking. These conditions "drove the Coloureds away from their homes and caused them to frequent the bars and bottle stores". ${ }^{132}$ Poor housing and living conditions were accompanied by low wages. The Meaker

\footnotetext{
${ }^{129}$ Cape Coloured Liquor Commission, 1945, p. 5.

${ }^{130}$ Select Committee on the Subject of the Liquor Bill, 1952. D. F. B. de Beers, Dutch Reformed Church, p. 47.

${ }^{131}$ Select Committee on the Subject of the Liquor Bill, 1952. D. F. B. de Beers, Dutch Reformed Church, p. 47.

${ }^{132}$ Cape Coloured Liquor Commission, 1945, p. 4.
} 
commission argued that "[p]overty and drunkenness, despite their apparent incompatibility, usually go hand in hand [...]". Many of the coloured witnesses to the commission frequently stated that the low wages paid to coloured labourers was a main reason for the drinking habits. ${ }^{133}$ The low wages often led to the disruption and even "breaking up of home life and neglect of children $[\ldots]$ ". Mothers and young children were then forced to work in order to help the family. Such conditions resulted in alcohol abuse, because "when the home is broken up the canteen becomes the haven of refuge". ${ }^{134}$ It is close at hand to reference Engels' description of the conditions for the English working class a century earlier. ${ }^{135}$ The poor living conditions, which characterized the streets of industrial capitalist England had been exported to Cape Town and other areas in South Africa. The abuse of alcohol was in both cases a result of the social conditions, under which the working class lived and at the same time the abuse of alcohol perpetuated the social conditions and class relations.

While men constituted the majority of heavy drinkers and drunkards, there were also some who were women. Apparently, they drank together with their husbands and families in towns. There were reports of "men, women and children" who had gathered in towns on Saturdays and waited for bars to open. At first they resembled "happy family picnickers", but when the wine had "done its work" the scene was less pleasant, according to the commission. Some witnesses claimed that for many of the coloureds the "week-end drunk" was seen as the only appropriate "reward" after having been deprived of joys during the working week. Since both men and women participated in the weekend drinking, it had the role of family entertainment. The children were clearly affected by such conditions, since they became accustomed to alcohol at an early age. ${ }^{136}$

On the farms the situation was better. Housing had been improved on many farms, and many farmers also provided gardens

\footnotetext{
${ }^{133}$ Cape Coloured Liquor Commission, 1945, p. 4.

${ }^{134}$ Cape Coloured Liquor Commission, 1945, pp. 4-5

${ }^{135}$ See Engels, 2009, p. 133.

${ }^{136}$ Cape Coloured Liquor Commission. 1945,
} 
for the labourers in addition to houses or cottages. The farm labourers had fewer expenses than labourers in towns, but wages were also lower. However, farm labourers had "difficulty in procuring clothing and furniture with the $£ 3$ or $£ 4$ [...]" they earned per month. And there was no "margin allowing for sums of money to be spent on alcohol". Wives and children, some of them very young, also worked and contributed to the family income, for example as seasonal and casual labourers on farms. Without their contribution the "position would be entirely hopeless". Next to the low wages, expenditure on alcohol by men was a crucial factor behind the poor social conditions for many families. Witnesses to the Meaker commission of 1945 "frequently" stated that some labourers spent half their wages on alcohol. Given the low wages, such families fell "below the breadline". This had happened in thousands of cases and had a profound impact on children especially. One teacher explained that the coloured children were "grossly underfed". Another teacher said that the children he taught "did not have the strength for hard physical exercises". But also adults were underfed, and some employers therefore gave their labourers food during the day, which improved their health and productivity. The "excessive amounts spent on alcohol" was regarded as a crucial factor behind the underfeeding. ${ }^{137}$

While farmers and the KWV insisted that the dop system was not harmful, they acknowledged that there were problems with alcohol abuse among the labourers. They mainly blamed the shebeens and canteens for such problems. And they emphasized that alcohol problems were worse in the towns than on the farms. H. F. Theron from the KWV asserted that there were many ways for labourers to "acquire a taste for liquor" and that the dop system could not be blamed for it. He also underlined that "the Coloured person on the farm is more sober than the Coloured person in the towns". ${ }^{138}$ While farmers argued that the dop system kept labourers away from canteeens and shebeens, the Temperance Alliance and other opponents of the system argued the opposite and won-

\footnotetext{
${ }^{137}$ Cape Coloured Liquor Commission, 1945, p. 8.

${ }^{138}$ Select Committee on the Subject of the Liquor Bill, 1952, H. F. Theron, KWV, p. 307.
} 
dered why farmers were always complaining that their labourers went to canteens. ${ }^{139}$

Since many farm labourers spent their money on alcohol in towns, there were requests from farmers to have a license to run farm stores. In those stores the labourers could buy supplies, which would make it unnecessary for them to go to town. Some farmers claimed that "when their workers go to town they go first to the bars and spend all their money and return home without the necessary food and clothing they went to obtain". ${ }^{140}$ By gaining control over how the labourers spent their money, the farmers could exert influence over them directly through what was provided in the farm store. But the farm store could also be used to indebt the labourers. Jan Theron argues that in Citrusdal during the 1970s, farm stores, where labourers could buy at credit, contributed to indebtedness. Once labourers were in debt, they found it hard to pay back except by working off the debt. ${ }^{141}$ For the farmers, a farm store could thereby serve a double purpose. It could retain the labourers, who had few means to pay, and it could keep labourers more sober, since they did not have to go to town.

While the dop system played a part in creating unhealthy drinking practices, the poor social conditions, especially in the urban areas, along with lack of other activities appear to have been the main reasons for drunkenness. In that regard, drunkenness was to a large extent caused by the prevailing social relations of production, which were based on racial segregation and low wages, and implied fewer options for social advancement for coloureds.

Another cause of alcohol abuse emphasized by the farmers, and one which should be considered more closely, was the legislation which stipulated partial prohibition of alcohol sale to coloureds. Until 1962, there was total prohibition on sale of alcohol to blacks, and partial prohibition for coloureds. That is, coloureds were allowed to purchase alcohol in certain places during certain times during the day. The hours of sale were more limited for coloureds

\footnotetext{
${ }^{139}$ Select Committee on the Subject of the Liquor Bill, 1952, A. G. Long, Temperance Alliance, p. 328.

${ }^{140}$ THINK, (Temperance Alliance), Oct., 1953.

${ }^{141}$ Theron, 1976, pp. 11-13.
} 
than for whites; the coloureds could only purchase alcohol during a few hours per day. Not surprisingly, wine farmers argued for no prohibition at all since that would increase their market considerably. But also other farmers underlined the importance of less prohibition. In short, the argument was that when coloureds went to canteens and bars, they only had a short time to finish before closing time. Therefore, they made sure they that drank as much as possible when it was possible. The same thing happened in the illegal shebeens. When the customers did not know if the police would come, they made sure that they at least had their bellies full. ${ }^{142}$ Different legislation would change the drinking patterns of coloureds and blacks, according to farmers. The KWV explained that the "fact that days and times of sales are drastically curtailed causes an increase in the illicit liquor trade because in consequence of it people are forced to go to shebeens in order to obtain liquor". But the limited times of sales also increased drunkenness. According to the $\mathrm{KWV}$, it was common that large numbers of coloured people "crowd together in the often small, cramped rooms of canteens in order to put away one drink after the other before closing time." Those who were drunk were apparently thrown out into the street and often ended up in the "arms of the law". The problem was thus that the coloureds, particularly the men, did not have the opportunity to gather with friends and have a drink. Due to the restrictions, they instead focused on "drinking as much as possible in the short time available". Unless legislation was changed, it would not be possible to "educate these people to be moderate drinkers", according to the KWV. ${ }^{143}$ Instead, the solution was to create drinking places for coloureds where not only alcohol, but also tea, coffee and sandwiches were served. Such places would "promote sobriety" among the coloureds. ${ }^{144}$

Coloureds on the farms were definitely also among those who drank too much, but usually not on the farms as it seems, and not during working hours. The problems with farm labourers, usually the males, who drank too much, began when work was done and

\footnotetext{
${ }^{142}$ Mager, 2010, p. 70.

${ }^{143}$ Select Committee on the Subject of the Liquor Bill, 1952, H. F. Theron, KWV, p. 292.

${ }^{144}$ Select Committee on the Subject of the Liquor Bill, 1952, H. F. Theron, KWV, p. 304.
} 
they went home to their families and drank in the house instead of helping their wives and taking care of their children. And the most severe problems appeared during the weekends when farm labourers went to town and visited bars and shebeens, where the liquor was stronger than on the farms, and where they could drink large amounts in short times and thus become "completely drunk". It is therefore possible to argue that the dop system in itself did not lead to drunkenness. Instead it created an addiction to alcohol, which in turn resulted in a craving for larger amounts of alcohol during the weekends. Farmers such as the one in Worcester, who challenged the Temperance Alliance to visit his farm with a doctor and find one labourer who was drunk, were therefore confident that no drunk labourer would be found. The labourers were not drunk at work, although they were perhaps not completely sober either. But instead, they were drunk when they were not working.

\section{Sobriety and labour - the view of labourers}

The farm labourers are notably absent in the list of witnesses to the various commissions investigating alcohol problems in the 1940s and 1950s. That is in itself an indication that the state did not value the opinions of farm labourers, but it also exemplifies that at least the coloured members of the working class were not expected or allowed to formulate and solve their own problems. This means that paternalism was not only a relation between farmers and labourers, it included all those who were involved in the public discussions about the dop system. It can perhaps be helpful to call this a form of public paternalism, which implied that all actors, except the labourers, were to take responsibility for farm labourers' problems and to find solutions. But although the labourers were not invited to discussions about the role of alcohol in their lives, they certainly also had opinions on the matter.

One coloured farm labourer, who was admitted to a clinic run by the Temperance Alliance, stated in the 1950s that the dop system in itself was the reason why he started drinking. He was about 45 years old and had grown up on a farm in the Western Cape, where the dop system was used. Apparently, he was introduced to the system at a very young age, since he noted that he "received the 
tots given out as soon as he was big enough to drink them" and that the "first drink he can remember taking was a tot". ${ }^{145}$ He did not specify when he was considered "big enough", but Schärf claims that there were many rumours in the 1970 s of children as young as seven years old who were given wine. ${ }^{146}$ Such practices were perhaps not common, though. More importantly, the farm labourer described that because of the tots he was given, he "rapidly $[\ldots]$ became a drunkard and unfit for work [...]". ${ }^{147}$ This can be compared with the notion that the labourers who were given wine clearly were in a dazed state most of the day, but still could work on the farms. This labourer, however, was actually unfit for work, which suggests that the alcohol had more severe effects on some. He seems to have left the farm where he grew up, but there were other farmers who wanted him. Due to his drunkenness, he had problems holding on to employment, though, and was "reduced to moving from farm to farm and being dismissed". ${ }^{148}$ As a result of excessive drinking, he was thus transformed from a permanent labourer to a casual and migrant labourer. Life as a migrant labourer was not preferred, since he did not have a house or a steady income.

After some time, the farm labourer apparently left farming and the dop system and became a fisherman instead. But he continued drinking and was sent to the institution run by the Temperance Alliance after having broken the law "repeatedly". When he was about to leave the institution, he wanted to go back to being a farm labourer, but not to the dop system. He had a friend who was a sober farm labourer and who worked on a farm where there was no dop system. ${ }^{149}$ It is important to notice that he wanted to stop drinking, since it demonstrates that there were farm labourers who did not approve of the dop system, and who wanted alternatives. The case furthermore illustrates how the dop system could continue although some labourers did not want it. When they started drinking they became addicted, which in this case influenced the

\footnotetext{
${ }^{145}$ THINK, (Temperance Alliance), April, 1954.

${ }^{146}$ See Schärf, 1984, p. 154.

${ }^{147}$ THINK, (Temperance Alliance), April, 1954.

${ }^{148}$ THINK, (Temperance Alliance), April, 1954.

${ }^{149}$ THINK, (Temperance Alliance), April, 1954.
} 
work. Those who wanted to stop drinking would have to find a farm where the dop system was not used. Such farms existed, but during the 1950s they were few. D. J. Naude, representing farmers from Swellendam to Vredendal in the Agricultural Union of the Winter Rainfall Area, explained in 1952 that the number of farmers who did not supply wine to their labourers were "very few". ${ }^{150}$ It was possible to move to a region where the dop system was not used, but such travels were long and expensive and labourers' mobility was limited.

Despite the many claims that coloured farm labourers were demanding to be given wine, it is clear that some of them resisted the system. The Temperance Alliance is one organization that could help them, but it is hard to determine to what extent, and if they were successful. The farm labourers who resisted the system were probably not many though, and in order for them to stop drinking it seems to have been a precondition that there were clinics or farms where no tots were given. To stop drinking while being on a farm where the dop system was practised was clearly difficult. While some farmers apparently did not approve of the dop system in the 1950s, they were relatively few, and it is hard to see that their farms could have functioned as refuge for those labourers who wanted employment, but without being given wine.

\section{Farmers who refused the system}

The practice of giving wine was clearly hard to abandon for many farmers, but those who had done so did not seem to suffer. According to Rev. De Beers from the Dutch Reformed Church, there were farmers who had stopped using the dop system and improved conditions for the labourers. As a result, sobriety had increased on those farms and the farmers had no difficulty finding labour. ${ }^{151}$ Others went even further than to just stop giving tots and refused to participate in producing wine altogether. One such farmer was G. F. Marais in Wamakersvallei in the Cape. Marais had a considerable wine farm with 65,000 vines in 1958. During the previous

\footnotetext{
${ }^{150}$ Select Committee on the Subject of the Liquor Bill, 1952, D. J. Naudé, p. 341.

${ }^{151}$ Select Committee on the Subject of the Liquor Bill, 1952, D. F. B. de Beers, Dutch Reformed Church, p. 68.
} 
twenty years, wine had generated 75 per cent of the farm's income. He was a member of the KWV and also a shareholder in a local cooperative winery, to which he delivered all his grapes. But in 1958 he resigned from both organizations and announced that he had "severed all connection with the wine industry as a matter of principle". Marais explained that he was concerned with the "havoc" that alcohol caused the coloured population. He therefore felt obliged to do something to reduce the damage caused by alcohol. He further explained that "no farmer could call himself part of the backbone of the country if his means of livelihood was a negative product". The matter was even noted in some of the major newspapers, for example in the Cape Argus. ${ }^{152}$ The fact that a farmer opposed the dop system, and wine farming, to the extent that he chose to stop it completely, was obviously considered as surprising. Such reactions imply that it was not expected that wine farmers voiced concerns about alcohol problems.

Marais would, however, not "uproot" his vines. Instead, he wanted to find a "profitable market for grape juice". His aim was "to find an effective substitute for alcohol". To shift production from wine to juice was definitely not common at the time, but Marais was not concerned that the new venture would be unprofitable and was convinced that "[a] great potential market lies open before us in South Africa and neighbouring countries". He hoped that his venture would lead to new research for a new cool drink which would replace alcohol. Unless there was an alternative to alcohol, the "evil of strong drink" could not be combatted, Marais argued.

When Marais suspended his wine farming, he also stopped giving the labourers tots of wine. As a result, a considerable number of the labourers left the farm. However, one of the labourers later returned to the farm, since he wanted to "improve [his] life a bit" and since he was "better without the drink". Subsequently, other labourers had also returned and Marais did not think he would have problems finding labour: "In fact, I'll be supplied with better workmen who will not get drunk each week-end." 153 Marais was apparently concerned about the quality of labour and that those

${ }^{152}$ THINK, (Temperance Alliance), July-Sept., 1958.

${ }^{153}$ THINK, (Temperance Alliance), July-Sept., 1958. 
under the dop system were less productive and caused more problems. But his view also indicates that he regarded the dop system as a source of drunkenness, not so much during the working days, but during the weekends.

There were probably not many farmers like Marais, who stopped using the dop system. But it is important to note that the reasons he gave for discontinuing it were personal, in essence that he did not approve of the results of excessive drinking, which was caused by the dop system. Marais pointed out that he expected to get better labourers, but that did not seem to be his initial motive. Those farmers who stopped giving wine because they wanted better labourers would have to be prepared to give considerably higher wages instead, perhaps 2s. more per day, which was more than $£ 3$ more per month per labourer. Not all farmers had the possibility, or were prepared, to increase wages to that extent. It was therefore not possible for all farmers to stop using the dop system even if they disagreed with it and if they wanted better labourers. Not unless they were prepared to give up some of their profits, that is.

Marais was probably a comparatively wealthy farmer with his 65,000 vines. As comparison we can note that in 1952 there were 4,450 wine farmers in South Africa, and in 1955 about 208 million vines, which means an average of 46,700 vines per farmer. ${ }^{154}$ His income was therefore probably higher than for the average farmer and he thereby had the means to pay higher cash wages. His reason for discontinuing the dop system was thus probably ethical in the sense that he did not agree with the effects of the system, but his opportunity to do so was based on his success as a farmer. The majority of farmers did not have the same possibility. It is thus clear that it was not enough for a farmer to oppose the system, it was also necessary for him to have the means to give alternative remuneration to the extent that labourers accepted not being given wine. Otherwise farming would not be profitable and the farmers would not be able to continue farming. It is therefore likely that there were other farmers who shared Marais' sentiment, but who

\footnotetext{
${ }^{154}$ Select Committee on the Subject of the Liquor Bill, 1952, H. F. Theron, KWV, p. 282; Agricultural census 1954-1955, p. 96.
} 
could not afford to stop using it. For the farmer, ethics was only worth as much as he could pay in wages.

\section{Abolition of the dop system}

It is hard to determine to what extent the dop system caused drunkenness and alcohol problems among farm labourers in the Western Cape during the 1940s and 1950s. Judging by the statements of the opponents to the system, it created and contributed to an addiction to alcohol. The defenders claimed that it was not harmful and that there were other sources of alcohol, which created more problems. The Temperance Alliance and the churches did not disagree with the notion that drinking outside the farm, for example in towns, was worse than the drinking on the farms, but they claimed that abolition of the dop system would decrease drinking in general. It is therefore possible to conclude that although the farmers gave wine to labourers, drunkenness was mainly a problem outside the production sphere. Drinking within the production sphere was definitely extensive, more than one litre per day per person, but it did not create drunkenness to any large extent as it seems. Or rather, farmers did not perceive it as a problem which required a solution.

But the opponents of the system would become more successful during the 1960s. Another select commission (Malan) was appointed to investigate the liquor legislation and reached the same conclusion regarding the dop system as the previous ones had done, that is, that it should be abolished. ${ }^{155}$ This also happened in 1963 when the Liquor Act was amended. The section regarding the dop system (96) was removed from the Act, but it was not forbidden for farmers to give wine for free to labourers. The system could thus continue as long as farmers did not use wine as wages and the changed legislation was not something wine farmers were concerned about, at least judging by the lack of statements on the subject in the annual reports of the KWV. ${ }^{156}$

\footnotetext{
${ }^{155}$ Report of the Commission of Enquiry into the General Distribution and Selling Prices of Intoxicating Liquor, 1960 (Malan).

${ }^{156}$ See KWV, Annual reports, 1960s and 1970s.
} 
The Temperance Alliance, which had criticised the dop system considerably since the turn of the century and especially during the 1940s and early 1950s, did not seem to bother about the changed legislation either. Their journal, THINK, did not report on the issue. The focus of the Temperance Alliance during the 1960s was instead the white alcoholics, not the coloured labourers on wine farms. Issues such as domestic violence, drunk driving and workrelated problems for whites dominated the journal. The introduction of apartheid and political pressure to focus on whites instead of coloureds could be seen as one explanation for the lack of interest from the Temperance Alliance for the abolition of the dop system. However, that explanation is incomplete, since the organization opposed the dop system considerably during the 1950s. The lack of interest is, however, one explanation as to why alcohol abuse continued among farm labourers in the Western Cape. When the strongest opponent to alcohol abuse did not take an interest in the problems on farms in the Cape, there were no others who did either. There were no trade unions and the government supported farmers, not farm labourers. Farm labourers who drank much were thereby left to themselves, at least until the Rural Foundation initiated projects for social upliftment in the 1980s.

While the debate during the 1940s, 1950s and 1960s about the abolition of the dop system and drunkenness was caused by concerns about the health of the coloured population and the effects of alcohol abuse on the labour force, there were other reasons behind the abolition of the dop system. The Malan commission in 1960 concluded that the regulation of the dop system in the Liquor Act of 1928 made it a

more permanent practice than would otherwise have been the case. It is today a fixed pattern from which farmers cannot easily depart, even though they may wish to do so. ${ }^{157}$

By regulating the amount of wine allowed to labourers each day, the Liquor Act had thus increased the problem, since labourers regarded the maximum amount of alcohol they could be given as the minimum amount farmers should supply to them, according to the

${ }^{157}$ Commission of Enquiry of Intoxicating Liquor, 1960, p. 12. 
Malan commission. Instead, the commission argued, the farmers should decide for themselves if they wanted to continue with the practice of giving wine, without government interference. There were some farmers who argued that supplying wine to labourers was an "unnecessary nuisance", since it meant that they supplied something the labourers could obtain elsewhere. But farmers apparently agreed that drunkenness during weekends would increase if labourers could only find liquor in towns. Therefore, it was better if coloured farm labourers could obtain liquor from the farm store or from the farmer. Then they would learn "how to use wine without abusing it", which indicates the central role of the paternalist practices in wine farming. According to the Malan commission, "[t]he need to supply wine to workers on farms at fixed times would then disappear and farmers who find it a nuisance today would be the first to put a stop to it". ${ }^{158}$ The dop system was then obviously not abolished because it was harmful to the labourers, quite the contrary. It was regarded as harmful to the farmers, who were bound by the legislation to provide a certain quantity of wine during the day. Therefore, the commission argued, farmers

should not be tied down by the Act if they do not want to supply their workers with any natural wine, or be prevented from doing so if they wish, and there should be no provisions as to the time and quantity of supply. ${ }^{159}$

In other words, farmers should be allowed to provide as much or as little wine as they wanted, when they wanted. Clearly, this meant that it was easier for some farmers to stop using the dop system, but for others it meant that they could give even more than they had done in the past, as there were no restrictions. We can therefore conclude that the purpose of the Liquor Amendment Act of 1963 was not to alleviate problems among labourers who were caught in a coercive system of labour control. The purpose was to aid farmers who were involved in a remunerative system that affected their possibilities of attracting labour at the price and in a manner that they desired.

\footnotetext{
${ }^{158}$ Commission of Enquiry of Intoxicating Liquor, 1960, p. 12.

${ }^{159}$ Commission of Enquiry of Intoxicating Liquor, 1960, p. 12.
} 


\section{WINDS OF CHANGE - TRANSFORMATION OF PRODUCTION AND LABOUR, 1950S TO 1990S}

\section{The labour force - race, gender and wages}

In the decades after the Second World War, South African agriculture underwent considerable changes. The apartheid policy benefitted many farmers, who could find cheap labour, but this was also an era of mechanization. For wine farming, the most important novelties were perhaps the introduction of harvest machines and chemicals for weeding in the 1970s. The introduction of new technology had an impact on labour demands, but not to the extent that could be expected. According to Reggie Africa, the mechanization of South African agriculture during the 1950s and 1960s did not result in a lowered demand on manual labour, quite the contrary. Mechanization instead meant higher productivity, which in turn generated a higher demand on manual labour, since the machines created new work operations, which required manual labour. ${ }^{160}$ However, we know little about wine farmers' reactions to the new technology and how that impacted the labour demands and labour relations. Let us therefore view how the labour force in some central wine farming districts developed during the period from the 1950s to the early 1990s. It is relevant to look at both racial and gender composition. The 1991 census did not enumerate

${ }^{160}$ Africa, 1977. 
farm labourers per se, only those involved in farming, but an absolute majority of coloureds and blacks in that category were farm labourers.

Table 1. Coloured and black farm labourers in wine producing districts 1955 and 1991.

\begin{tabular}{|c|c|c|c|c|c|c|}
\hline & \multicolumn{3}{|c|}{ Coloured } & \multicolumn{3}{|c|}{ Black } \\
\hline 1955 & Male & Female & Total & Male & Female & Total \\
\hline Stellenb. & 3,002 & 1,579 & 4,581 & 940 & 44 & 984 \\
\hline Paarl & 4,338 & 631 & 4,969 & 1,159 & 50 & 1,209 \\
\hline Robertson & 2,775 & 103 & 2,878 & 186 & 7 & 193 \\
\hline Malmesb. & 3,876 & 144 & 4,020 & 619 & 12 & 631 \\
\hline Wellington & 1,511 & 65 & 1,576 & 136 & 1 & 137 \\
\hline Worcester & 5,383 & 1,388 & 6,771 & 453 & 151 & 604 \\
\hline Total & 20,885 & 3,910 & 24,795 & 3,493 & 265 & 3,758 \\
\hline 1991 & Male & Female & Total & Male & Female & Total \\
\hline Stellenb. & 3,225 & 1,952 & 5,177 & 1,041 & 212 & 1,253 \\
\hline Paarl & 6,628 & 4,414 & 11,042 & 2,137 & 782 & 2,919 \\
\hline Robertson & 4,011 & 2,475 & 6,486 & 537 & 133 & 670 \\
\hline Malmesb. & 5,083 & 1,472 & 6,555 & 1,802 & 126 & 1,928 \\
\hline Wellington & 2,370 & 1,233 & 3,603 & 288 & 100 & 388 \\
\hline Worcester & 8,824 & 7,258 & 16,082 & 2,139 & 1,129 & 3,268 \\
\hline Total & 30,141 & 18,804 & 48,945 & 7,944 & 2,482 & 10,426 \\
\hline
\end{tabular}

There was an obvious overall increase in the number of farm labourers in these districts between the 1950s and 1990s. We can be certain that it was only marginally caused by an increased number of farmers, since there were 4,450 wine farmers in South Africa in 1952 and about 4,700 in $1995 .{ }^{161}$ The average number of labourers per farm thus increased considerably, which also means that the farmers managed to hire more labour. Increased mechanization af-

\footnotetext{
${ }^{161}$ Select Committee on the Subject of the Liquor Bill, 1952, H. F. Theron, KWV, p. 282; Farm Labour Review, 1996, p. 207.
} 
ter the 1970s did consequently not lead to a lowered demand on manual labour, quite the contrary. It appears that mechanization resulted in increased production, increased profits and more manual labour.

One notable transformation in these districts between the 1950s and 1990s was the increased number of black farm labourers. In 1955, the black labourers made up about 13 per cent and in 1991 they made up about 18 per cent. This is important to consider, since previous research often emphasizes the role of coloured labourers in wine farming and in the dop system.

While coloured and black women only made up a small part of the labour force in the 1950s, their share was considerable in 1991. It was especially the coloured women who took part in the labour force. Their share increased from about 14 per cent in 1955 to 35 per cent in 1991, indicating that the role of coloured women had changed. They were no longer only working in the household or as seasonal labourers; they were part of the farm labourers. It is likely that farmers hired women because they could be paid lower wages than men. But it could also have been an indication that the work operations changed due to mechanization and therefore required less strength. Therefore, women could perform much of the work as well as men could. In Worcester, the coloured women made up as much as 45 per cent of the coloured labourers. This was also the district where the share of black labourers increased the most. In 1991, 54 per cent of the labour force was made up by blacks and coloured women.

The hiring of blacks and of coloured women should be regarded as strategies used by farmers to reduce expenditure on wages. Blacks and coloured women have been regarded as the lowest paid categories of labourers. But the relationship between race and wages is slightly more complex than what is usually stated. In 1955 , the wage per person was $£ 6.6$ for coloureds and $£ 7.1$ for blacks. ${ }^{162}$ Black labourers were at that point in time obviously not hired because they were cheaper. But during the 1960s and 1970s, the

\footnotetext{
${ }^{162}$ Agricultural census 1954-1955, pp. 36-37, 40-45.
} 
wage structure changed. We can look at average wage per person according to race in 1975 .

Table 2. Average expenditure on wages, cash and value in kind (Rand), per person in 1975 in wine farming districts.

\begin{tabular}{lcc}
\hline & Coloured & Black \\
\hline Stellenbosch & 649 & 578 \\
Paarl & 569 & 515 \\
Robertson & 479 & 422 \\
Malmesbury & 648 & 550 \\
Wellington & 530 & 471 \\
Worcester & 506 & 450 \\
\hline
\end{tabular}

Source: Agricultural census 1975, pp. 73, 93.

While coloureds definitely earned more than the blacks, we must also acknowledge that there was a difference between the districts. In Stellenbosch, Paarl and Malmesbury, the wages were comparatively high for both blacks and coloureds, whereas wages in Robertson were at very low levels. But we must remember that wages were not only paid in cash. Also wages in kind affected wage levels. Since the dop system was an intricate part of the remunerative practices, it is relevant to look more closely at how they changed in the central wine farming districts. 
Table 3. Ratio of wages to permanent coloured and black farm labourers (cash and in kind) 1955 in $£$ and 1975 in $\mathrm{R}$ in wine farming districts.

\begin{tabular}{lcc|cc}
\hline & \multicolumn{2}{c|}{1955} & \multicolumn{2}{c}{1975} \\
\hline & Cash $£$ & Goods $£$ & Cash R & Goods R \\
& $1,000(\%)$ & $1,000(\%)$ & $1,000(\%)$ & $1,000(\%)$ \\
\hline Stellenbosch & $26.3(87)$ & $3.8(13)$ & $194,7(90)$ & $207(10)$ \\
Paarl & $31.7(84)$ & $6.0(16)$ & $323,4(89)$ & $417(11)$ \\
Robertson & $16.0(81)$ & $3.9(19)$ & $139,0(85)$ & $251(15)$ \\
Malmesbury & $17.4(43)$ & $22.6(57)$ & $205,6(58)$ & $151,0(42)$ \\
Wellington & $7.6(75)$ & $2.6(25)$ & $852(84)$ & $164(16)$ \\
Worcester & $36.3(72)$ & $14.3(28)$ & $396,1(84)$ & $748(16)$ \\
\hline Total & $135.3(72)$ & $53.2(28)$ & $1344(80)$ & $3298(20)$ \\
\hline
\end{tabular}

Source: Agricultural census, 1954-1955, pp. 40-41, 44-45; Agricultural census 1975, pp. 73, 93.

It is clear that during the period between 1955 and 1975 the share of cash wages increased overall in the wine farming districts. In some districts, such as Stellenbosch, the transformation was marginal, but in others, such as Worcester and especially Malmesbury, where the ratio changed from 43 to 58 per cent, it was substantial.

Since wine was not allowed to be given as wages, it is unlikely that farmers included it in their census returns. Wine was more likely given in addition to the cash wages and the rations, although it was part of the wage in real terms. The change in remunerative practices, however, reflects what has been indicated by Schärf and Theron, that the tots of wine were given less frequently and in smaller amounts, during the 1970s and 1980s. ${ }^{163}$ The decreasing role of the dop system was therefore part of a larger trend in wine farming areas, which meant more cash wages and less wages in kind. It is thus possible to argue that the decreasing role of the dop system was not only a result of changes in farmers' attitudes, it was also a result of capitalization of wine farming and more cash wages instead of other forms of remuneration.

From the above we can conclude three things, which are important to consider for the analysis of remunerative practices: First-

\footnotetext{
${ }^{163}$ Schärf, 1984; Theron, 1976.
} 
ly that cash wages became more common instead of rations. Secondly that black men and women and coloured women became increasingly important as farm labourers. Thirdly that the wage levels differed considerably between the districts, which suggest that there was a stratification of farmers. Some farmers were more successful and could pay more and higher cash wages, others relied more on rations and lower wages overall. We will now consider why such changes occurred and how it affected the farmers and the labourers.

\section{Winds of change in the vineyards}

During the 1970s, the monopoly role of the KWV was criticized by farmers, who wanted independence. One of the pioneers of this movement was Michael "Spatz" Sperling, a German immigrant who arrived in South Africa after the Second World War and bought the farm Delheim. Together with Frans Malan at Simonsig and Niel Joubert at Spier, Sperling established the Stellenbosch Wine Route in 1971. ${ }^{164}$ The purpose was to create an interest for wine in South Africa. Although wine had been produced in the country since the seventeenth century, it was not a wine-drinking country, and production on farms was mainly focused on distilling wine. Only in 1953 did production of table wine exceed production of fortified wine. ${ }^{165}$ The KWV fixed the prices for distilling wine, which meant that most farmers produced for that purpose, or did at least not focus on producing quality wine. But it was also easier to export fortified wine than natural wine from South Africa to Europe, which contributed to lower production of quality wine. The wine route was supposed to change the market for wine in South Africa, by creating an interest in wines through, for example, wine tastings.

The wine route was accompanied by another innovation in 1973: the "wine of origin" system. Sperling, Joubert and Charles Back, together with the wine industry research institute Nietvoorbij in Stellenbosch, were behind its establishment. ${ }^{166}$ The purpose of

\footnotetext{
${ }^{164}$ Wynboer, June, 1992.

${ }^{165}$ Viall et al., 2011, p. 97.

${ }^{166}$ Viall et al,. 2011, p. 99; Vink et al., 2004, p. 235.
} 
the system was to improve the quality of wine through a guarantee of the contents. According to Sperling, an important reason for such a system was to meet demands for regulation in Europe. ${ }^{167}$ Exports thereby contributed to increased quality of wine in South Africa, which had been the case also with, for example, wool exported to Britain. The wool quality guarantee was established in the 1930s, and in comparison, as Sperling notes, the wine farmers were late with their quality guarantee. ${ }^{168}$

Due to the role of the KWV, most farmers had focused on producing large quantities instead of high quality. Some argued that the KWV's control diminished the farmers' willingness to improve production and invest in their farms, since they could rely on the KWV to help them to secure profits. The farmers who initiated the wine route instead wanted to invest in their farms in vines of higher quality, which would generate higher income. The interest in wine was thus closely related to higher quality.

The wine route was initially small, but quickly expanded. In 1975, Wynboer explained that the estate wineries had emerged during the past few years, but had increased in number to the extent that they had an association, the Stellenbosch Estate Wine Producers (Co-op) Ltd. The association was exclusively for estates, that is, farms that produced wine under their own label. Frans Malan was chairman in 1975 and was himself the owner of two estate wineries, Simonsig and De Hoop. During the following decades, the membership numbers increased and in the early 1990s the number of estates involved in the wine route was about twenty, but also five co-operatives were members. ${ }^{169}$ The route, and membership in the association, was clearly exclusive, considering that there were about five thousand wine farmers in the country. Most of the farmers did thus not benefit from the wine route through tourism during the 1970s, 1980s and 1990s, although they might have benefitted from an overall increased interest in wine. In the early 1990 s, the wine route had 500,000 visitors per year and the KWV

\footnotetext{
167 "Spatz" Sperling, quoted in Viall et al., 2011, p. 99.

${ }^{168}$ Viall et al., 2011, p. 99. Lilja, 2013.

${ }^{169}$ Wynboer, June, 1992.
} 
celebrated it. ${ }^{170}$ However, in the mid-1980s, wine was still mainly consumed in the Western Cape, where consumption was far ahead of the rest of the country. ${ }^{171}$

The wine of origin included demarcation of geographical area of origin, grape variety and vintage year. The farm or estate was the smallest unit that could be used to designate origin, followed by division, district and region. At least 80 per cent of the contents of a bottle had to originate from the area if a producer wanted to use the label. There were also two categories for estate wine: those that were grown, produced and bottled on the estate and those that were bottled outside the estate. The KWV supported the system and recognized the benefits for both producers and consumers. The producers were given a brand name for free and if the quality was of a certain standard they would be recognized for it. For the consumers the system guaranteed that they knew what they bought and could find what they wanted to drink. ${ }^{172}$ It appears that the wine of origin was beneficial to the entire wine industry. During the late 1970s and 1980s, the KWV's profits increased steadily, except for one year, $1981 .^{173}$

The wine of origin system did not mean that all farmers tried to become estate producers. The number of co-operative cellars increased continually and numbered 69 in $1975 .{ }^{174}$ However, the system created incentives for those who wanted to produce quality wine and benefitted them if they could produce it. In 1985, the farm Altydgedacht in Durbanville, owned by the Parker family, was recognised as an estate that produced its own wine under its own label. However, the Parker family still depended on cooperatives; they only bottled about five per cent of their crop under their own label. The rest was sold to others. To start an estate was clearly expensive for those who did not have much capital and the Parkers used material that was available on the farm for production of wine, such as oak vats and cement tanks. They also bought two milk tanks second hand and used them for cold fermentation

\footnotetext{
${ }^{170}$ Wynboer, June, 1992.

${ }^{171}$ Farmers' Weekly, Jan. 4, 1985.

${ }^{172}$ KWV Annual Report, 1972, pp. 3-4.

${ }^{173}$ KWV Annual Report, 1992.

${ }^{174}$ Vink et al., 2004, pp. 233-34.
} 
for white wines. ${ }^{175}$ For farmers like the Parkers, estate wine production thus had to start on a small scale if it was to be profitable. Others had more capital and could invest larger sums in their farms.

The changes in marketing through the wine of origin system could not have been profitable for farmers unless they also changed production, though. The planting of quality vines was a long-term investment. Malan at Simonsig was the first farmer in South Africa to produce Chardonnay. He started experimenting with the cultivar in 1974 and only in 1977 was the first Chardonnay wine produced. The long-term investments definitely meant that income could not be expected the following year, which was the case for those who delivered to co-operatives, which secured income for farmers after each harvest. And investments could also prove to be worthless. Malan planted an additional vineyard with what he thought was Chardonnay vines in 1981, but it proved to be another grape, Auxerrois, and was therefore destroyed. In 1985, he again expanded his Chardonnay vineyards. Malan planted 20,000 vines and expected the first grapes to come "in about three years". ${ }^{176}$ It is likely that the long-term investments kept many farmers from planting quality vines and attempting to become estate producers. The quality, or premium, cultivars only made up 6.5 per cent of the vineyards in 1980. In 1990, that number had increased to 12 per cent. ${ }^{177}$ It was thus after 1980 that the production of quality wine became more widespread. But already in the 1970s there were farmers who were interested in attempting to transform their production, primarily with a focus on harvesting.

\section{Harvest time and new technology}

In 1975, mechanical harvesting was tried for the first time in South African wine farming. According to the wine farmers' journal, Wynboer, there was much interest in the new machinery and expectations of their capacity "for they represent the most comprehensive innovation the world's wine-farmers have known". The

\footnotetext{
${ }^{175}$ Farmers' Weekly, Sept. 20, 1985.

${ }^{176}$ Farmers' Weekly, Jan. 10, 1986.

${ }^{177}$ Vink et al., 2004 p. 237.
} 
machines would impact all aspects of wine farming, according to Wynboer: "the labour structure, the selection and husbandry of the grape, the handling and processing thereof, and the quality and marketing of the final product will feel the influence of the new technique". ${ }^{178}$ The impact of machine harvesting might not have been profound, though. In 1993, there were about 50 or 60 grape harvesters in South Africa and Ewert and du Toit mention that in 1995 there were 95 harvest machines in the country. ${ }^{179}$

Compared to manual harvesting, machines required changes in the vineyards. For the best results the rows of vines should be as long as possible and adjoining vine blocks should be of the same variety, since that meant uninterrupted harvesting. Further, there should be enough room for the machines to turn quickly between rows and large rocks or irregular ground had to be removed. The trellising of vines should be conducted so that the vines grew vertically, using several parallel wires, and keep the vines from growing close to the ground. But also the roads to the vineyard should be in "good condition" in order for tractors and trailers to drive quickly and thereby be able to go to, and return from, the cellar as quickly as possible. ${ }^{180}$ The mechanical harvesting therefore required investments into the farm in addition to the machine itself.

There were no indications in the farmers' journal of how machine harvesting would affect labour. But since we know that the number of labourers in wine farming continued to increase until the 1990s, it appears that it did not reduce the demand for labour at all. The introduction of machinery, however, caused reactions among labourers. Jannie Bosman on Bosman family vineyards in Wellington remembers that when he first tried harvest machines, the labourers commented on how poorly the machine worked. They pointed out that the machine missed bunches of grapes and damaged the vines, which they themselves did not do during harvest. ${ }^{181}$ The labourers' comments can be interpreted as a strategy, where they emphasized quality in the production process. Thereby,

\footnotetext{
${ }^{178}$ Wynboer, Aug., 1975.

${ }^{179}$ Wynboer, Feb., 1993; Ewert and du Toit, 2005, p. 328.

${ }^{180}$ Wynboer, Aug., 1975.

${ }^{181}$ Jannie Bosman, Bosman Family Vineyards, interview, 2013-12-10.
} 
they reassured the farmer that a machine was not necessary and would in fact lower the quality of production. The recommendations from labourers were perhaps not important for the farmer's decision on whether or not he should use a machine for harvests, but he agreed with them that it was not necessary and did not continue to use it. According to Jannie Bosman, he preferred manual labour instead of machinery. Mechanization was done on the farm, but, according to him, only to facilitate manual labour.

The first tractors were used on Bosman in the 1960s. The tractors increased production, which meant that more labour was demanded. Bosman notes that machines were used to keep the costs of labour down, but mechanization was not an aim in itself. Machines have mainly been implemented where it could be done without firing people and have been used to provide a good environment for labour, according to Bosman. ${ }^{182}$ This aim, which is based on the premise that labourers are valued, is perhaps not representative of wine farmers in the Western Cape, but demonstrates that mechanization of some areas of farming has not been necessary, and not even advantageous in some regards. Manual labour at a low cost and mechanization of only some parts of farming could thus be a successful strategy. But such a strategy of course requires that farmers had enough assets to be able to employ a large labour force. On Bosman's three farms there are about two hundred labourers, which is more than what most farmers can afford.

While harvest machines were not extensively used, the harvest could be mechanized in other ways. In table grape farming, and presumably in wine farming as well, the transport of grapes from the rows in the vineyard could be much improved. By carrying the grapes in trailers, the time spent on harvesting could be increased to as much as 75 per cent, compared to 66 per cent when the grapes were carried out manually. This form of mechanization reduced "exhaustion of the workers (particularly when it is hot) [...]", which was clearly beneficial to productivity. But there were other benefits, since it also ensured "a smoother operation", mean-

\footnotetext{
${ }^{182}$ Jannie Bosman, Bosman Family Vineyards, interview, 2013-12-10.
} 
ing that the harvested grapes flowed better. But most importantly, "the speed of the tractor and trailer determines the speed of harvesting - not the workers, as is the case where mechanisation is not used". ${ }^{183}$ Mechanization of certain parts of the harvest thus meant that labourers had become appendages to the machines in some sense. They could no longer control the work pace, which was set by the machines. The difference in productivity was noticeable. When grapes were harvested into baskets and carried either manually or on trailers, the productivity was $75 \mathrm{~kg}$ per man per hour. However, with a "bulk container" the productivity increased to as much as $195 \mathrm{~kg}$ per man per hour. This meant that the vineyards had to be prepared for large containers to be able to drive between rows and collect the grapes since a "good vineyard can be harvested more efficiently than a poor one". ${ }^{184}$

There were other improvements in wine farming in addition to harvest machines, though. Mechanized irrigation was introduced, for example, and in the 1980s computerized irrigation was available to those who could afford it. Also weeding was transformed through the use of pesticides, which replaced many labourers. Other labour intensive operations such as trimming and pruning could also be done by machines in the 1980s. Hydraulic pruning shears could reduce the time spent on pruning by between 17 and 30 per cent. But they also impacted the labourer conducting the pruning and meant that lower wages could be paid since pruning was made "easier and less physically taxing, so women can be more readily used for this". ${ }^{185}$ The increased number of women in the farm labour force in wine farming areas during the 1970s and 1980s should definitely be regarded as a result of the implementation of these and other machines. Since machines facilitated some work operations physically, it was possible to hire women to do the same work as men for lower wages.

In most instances the machines did not replace manual labour, though. Instead it was used to make labour more efficient. In the mid-1980s, the farmer Eddie Malan at Van Riebeeck's Hof close to

\footnotetext{
${ }^{183}$ Farmers' Weekly, June 27, 1986.

${ }^{184}$ Farmers' Weekly, June 27, 1986.

${ }^{185}$ Farmers' Weekly, June 27, 1986.
} 
Durbanville used a trimming machine, which cost about R16,000. Trimming should be done towards the end of the growing season, before the harvest, to improve circulation in the vineyards. The trimming machine was attached to the tractor and a tractor driver could learn how to use it within a few hours, according to Malan. The machine was also used for pruning in the winter time. Malan wanted a few "'specialist' pruners" and these could be helped by the use of the machine. When there were long canes in the vineyards they had to spend much time removing those "before getting down to the accurate pruning". By using the machine to cut off excess wood, the workload for the pruners was easier and it enabled them to "do a better job". ${ }^{186}$ The machine was thus used together with manual labour, and actually assisted the labourers instead of taking their place, since correct pruning required skills and accuracy.

But in many aspects machines were clearly both time and laboursaving. In nurseries where vines were cultivated for sales, topping was an important work operation, which was also labour intensive and time-consuming. It took four labourers a whole day to top one hectare of grafted canes. By using a topping machine drawn by a tractor, one labourer could alone conduct the same work operation in only three hours. ${ }^{187}$ The topping machine was not expensive, since it was made at the nursery from scrap parts and sheet metal. Such investments were definitely available to those farmers, who did not want to spend large sums on expensive machinery, but it also required some knowledge about machinery, and most farmers appear to have continued using manual labour for such work operations. Labour was comparatively cheap and for those farmers who delivered to co-operatives there were few reasons to change production.

\section{Division of labour, skills and training}

The period of change in the vineyards, which meant more focus on quality wine and improved production, resulted in changes in the labour relations. Above all it required a more skilled and responsi-

\footnotetext{
${ }^{186}$ Farmers' Weekly, May 9, 1986.

${ }^{187}$ Farmers' Weekly, March 1, 1985.
} 
ble labour force, for example for work operations such as tractor driving, pruning, irrigation and harvesting. This, in turn, meant that farmers had to invest in their labourers in order to get expected profits back. This trend has been described by Mason, who argues that fruit farmers in the Western Cape started to involve labourers in the decision-making process, tried to increase their productivity and did not allow drinking at work. ${ }^{188}$ However, this process also meant that the work operations on the farm became subject to specialization, indicating that not all farm labourers could perform the same work operations, and that farm labour in itself became more hierarchical.

There is reason to challenge the widespread notion that farm labourers were not skilled. What it refers to is usually that they were not trained to operate machinery, for example tractors. But farm labourers were not unskilled before tractors were implemented in farming. They ploughed with horses, trimmed vines, constructed buildings, milked cows, herded sheep etc. All of those work operations required certain skills. However, unlike tractor driving they were not learned formally through courses with certified instructors, but were learned on the farm, often from generation to generation. The skilled labour referred to by Schärf was thus the labour that included new technology, which was learned outside farms, through instructors or even in schools. We must thus be observant when discussing skilled and unskilled labourers. Those labourers, who were regarded as unskilled in the 1970s were the ones who were not trained to operate machinery such as tractors, but that does not mean that they were without skills.

According to Marcus, South African farming went through a restructuring process during the 1960s and 1970s, which created a skill hierarchy among labourers. ${ }^{189}$ Some farm labourers were thus trained for tractor driving etc., which meant that they acquired such skills and were paid higher wages. Thereby a differentiation of the labour force began. Those with skills were better paid than those without skills, although all farm labourers were paid com-

\footnotetext{
${ }^{188}$ See Mayson, 1990, pp. 212-13, 256-58.

${ }^{189}$ Marcus, 1989, p. 114.
} 
paratively low wages, according to Marcus. ${ }^{190}$ But the differentiation, or stratification, was an important tool for farmers to separate labourers from each other. At the same time there was an individualization of labourers, which was a general result of the decreasing use of labour tenancy, a practice that implied that an entire family was expected to work for the farmer. Instead labourers were hired individually, often as migrant labourers. ${ }^{191}$ But Marcus fails to analyse how also the stratification of the labour force resulted in an individualization of labourers. If we want to understand how labour relations in Western Cape wine farming changed during the 1970s and 1980s, that process must be analysed.

Farm labourers were not only less "skilled" than many other categories of labourers. Schärf even notes that farm labourers in wine farming were "deskilled", since they were not taught any skills that could be used in other sectors than farming, and since they had little possibility to educate themselves or acquire other skills which could make them attractive to employers outside agriculture. The dop system and alcohol problems further added to the deskilling of farm labourers in the Western Cape, according to Schärf, as addiction to alcohol kept the labourers on the farms. However, when tractors became more common in farming, which occurred over a long period, but mainly after the 1960s, labourers had to be trained to drive them. This can be seen as the first stage of training for the farm labour force. Tractors were of course not only used in wine farming, but in most farming sectors, which means that there was a broad skill training of farm labourers in South Africa. Both black and coloured farm labourers were part of this process. The Bantu Education Act from 1953, for example, stipulated that many blacks were expected to be farm labourers and therefore only had to learn those skills necessary for farming. ${ }^{192}$ Gradually, that included tractor driving, for example, but mainly manual work.

While for example tractor driving was common in all farming sectors, other work operations were specific to wine farming, such

\footnotetext{
${ }^{190}$ Marcus, 1989, p. 180.

${ }^{191}$ Marcus, 1989, pp. 91-92.

${ }^{192}$ See Tabata, 1960.
} 
as pruning and trellising. Training for those work operations was specifically directed at labourers on wine farms. In 1985, the first course for coloured foremen and overseers in "advanced vineyard management" was conducted in Stellenbosch. Beyers Truter from Kanonkop and Johan Carinus arranged the course with the aid of the Stellenbosch Farmers' Association. There was apparently a demand for the course, since 65 coloured foremen and overseers attended it. The previous year a course in cellar technology had been arranged by Truter, and he explained that the two courses would be alternated annually in the future. ${ }^{193}$ Clearly, then, the demand for improved skills among the labour force required that the farmers invested in them. It appears that it was individual farmers or winemakers who took the initiative, and that the Stellenbosch Farmers' Association supported them with funding. As the course was specifically for coloured foremen and overseers it appears that this was a position that coloureds, but not blacks, could access in the Western Cape. There were black labourers in wine farming, but these were probably not allowed to be foremen or overseers. In the 1970s and early 1980s, there were only two training centres or colleges for farm labourers, one for coloureds and one for blacks. The one for coloureds, Kromme Rhee, was situated close to Stellenbosch.

In the mid-1980s, the Kromme Rhee Agricultural College offered various training courses for coloured farm labourers. The college offered courses for "supervisors, senior work foremen and work foremen". ${ }^{194}$ These courses appear to have been aimed specifically at the strata of labourers who were in supervisory positions. But there were also courses aimed at training labourers in pruning of vines and fruit trees, livestock care and maintenance of farm implements and truck and tractor courses. ${ }^{195}$ For the tractor courses there were both maintenance and drivers' license courses. In 1985, the course was divided into three different levels: "basic, advanced and drivers' license". ${ }^{196}$ This suggests that not all farm labourers

\footnotetext{
${ }^{193}$ Farmers' Weekly, Aug. 30, 1985.

${ }^{194}$ Farmers' Weekly, Jan. 11, 1985.

${ }^{195}$ Farmers' Weekly, Dec. 6, 1986.

${ }^{196}$ Farmers' Weekly, Jan. 11, 1985.
} 
were expected to learn how to drive the tractors. Driving was reserved for some, while others were expected to learn how to maintain the tractors. But it is also possible that there was a progression in the courses, so that labourers started at the maintenance level and continued later with drivers' license.

The variety of the courses at Kromme Rhee aimed at wine, fruit and livestock indicates that most farming sectors in the Western Cape were included and that farmers could send labourers to the college. But also in this case the training was reserved for coloured farm labourers. There were similar training facilities in other parts of South Africa, which accepted labourers of all races. ${ }^{197}$ The black farm labourers were thus also trained, but not in the Western Cape.

In some parts of South Africa it was possible for farmers to contact training centres, which came to the farm to conduct training of the farm labourers. The large estates wanted such mobile training units to train their labourers. It was more common, though, that local farmers' associations contacted the training centres and asked for specific courses to be held. While increased skill was the main aim of such courses, there would be a "long-term bonus" as well: it was hoped that the training would generate a "reduction in worker mobility resulting in workers and their children remaining on the farms despite the lure of the cities". ${ }^{198}$ Farmers must have noticed that the migration of farm labourers to cities was to a great extent caused by the low wages and poor conditions on the farms. Although farmers were not prepared to increase wages to the same level that was found in industries, they found that they could retain the labourers if they invested in them.

Farmers themselves had to enrol their labourers to these courses. The labourers could therefore not choose their own training unless they had the money to pay for it. Labourers who were interested in certain training could perhaps ask the farmers to be sent for a course, but it is more likely that farmers made decisions based on what was required on the farm. If tractor drivers were required, they would choose those labourers they saw as most suitable for

\footnotetext{
${ }^{197}$ Farmers' Weekly, Feb. 7, 1986.

${ }^{198}$ Farmers' Weekly, Feb. 7, 1986.
} 
the job and send them for a course. This of course meant that labourers saw that there was a chance for advancement on the farm, and probably a higher wage if they acquired additional skills. This in itself could have affected many farm labourers' attitude towards alcohol. According to Schärf, one of the reasons for alcohol problems among farm labourers was the lack of opportunity of advancement. But when there was an opportunity of advancement it seems likely that farm labourers had a reason not to drink, at least not to the extent that it affected their work. Sobriety was a precondition for acquiring skills and advancing on the farm.

\section{Division of labourers - management and individualization of labour}

The increased specialization of the labour force was accompanied by new management styles. Schärf and Mayson refer to the methods that were introduced in the 1970s and 1980s as cooptive, which were different than the coercive methods which had been used previously. ${ }^{199}$ But it is important to be more specific regarding the analysis of management strategies. For the farmers were not only changing to cooptive methods, they also used management as a method of dividing the labourers into groups based on their performance. This was seen in many parts of South Africa during the 1980s, not just in the wine farming areas.

There was obviously awareness among farmers that management methods could be used to increase productivity on the farm. Arnold Mol, lecturer in the Department of Business Economics at the University of South Africa, noted in 1985 that he had seen "remarkable changes on farms where the farmer has changed his approach to his workers". ${ }^{200}$ Instead of assuming that farm labourers were lazy and did not want to work or did not work without constant supervision, many farmers had started to include labourers in decision making and allowed them to take responsibility.

This management method required that each labourer should be treated individually according to their own capacity. When the labourer performed well he should be praised and shown as an ex-

\footnotetext{
${ }^{199}$ See Schärf, 1984, p. 149; Mayson, 1990, p. 271. Mayson also uses the term consent.

${ }^{200}$ Farmers' Weekly, Nov. 15, 1985.
} 
ample to others. There were many advantages in doing so; the labourer was encouraged to keep up his good work and even "better his record", but it also meant that the other labourers were "spurred on to compete for the farmer's accolade". ${ }^{201}$ Those labourers who performed well would benefit both financially and emotionally, since they could receive bonuses or higher wages and gain recognition for their work from the farmer. Constant communication with the labourers could also generate better results than offering higher wages. By praising the labourers when they performed well, "a farmer can go a long way towards creating an enthusiasm for the job which no bonus could ever do". ${ }^{202}$ In many ways this method resembled the paternalist practices, since the personal relationship between farmer and labourer was reinforced. However, it is likely that it kept productive and well-behaved labourers closer to the farmer, while it created a distance to those who were less productive and did not behave in a manner which the farmer wanted.

Arnold Mol held courses for farmers from at least 1980, and many of them seem to have followed his recommendations. A farmer in the Transvaal, Wickus Stols, had attended one of Mol's courses and started practising the new methods on his sheep and maize farm. He found that the labourers performed better and that the profits increased. Most importantly, Stols was able to spend more time on management than on supervising the work. ${ }^{203}$ The first measure he took was to tell the labourers to elect a liaison committee that could meet with him and discuss how work should be conducted. Incentives were created for the labourers: "For every farm skill they mastered they were paid more." A tractor driver could thus earn more money if he also learned welding, and he could earn even more if he "also passed a tractor-maintenance course". But cash incentives were not always necessary. Stols explained that "[a] pat on the back and a few sincere words of thanks on a job well done works wonders". ${ }^{204}$ The new methods of

\footnotetext{
${ }^{201}$ Farmers' Weekly, Nov. 15, 1985.

${ }^{202}$ Farmers' Weekly, Nov. 15, 1985.

${ }^{203}$ Farmers' Weekly, June 7, 1985.

${ }^{204}$ Farmers' Weekly, June 7, 1985.
} 
management did therefore not necessarily have to imply higher wages, at least according to farmers. It is unclear if the labourers preferred higher wages or more gratitude from the farmer. We can expect that gratitude alone did not work as well if there was no wage increase to accompany it, but it is important to note that the new methods were not only based on higher wages. There were definitely benefits for the labourers, though. Stols mentioned that the increased productivity meant that labourers could be given more leave and a bonus. Also Stols himself benefitted, since the labourers did not leave the farm for higher wages elsewhere and labourers from neighbouring farms came to his farm applying for a job. ${ }^{205}$

Throughout the country, farmers were thus aware of new methods of management. Wine farmers were clearly involved in the process at the frontline and were among those driving the process of change. Danie Hofmeyr at Amalienstein in the Swartberg area between Calitzdorp and Ladismith was among those in the Western Cape who were quick to change to new methods. Hofmeyer farmed wine and a mixture of other crops including fruit and onions. On his farm there were about 40 permanent labourers and 200 labourers during harvest time. He was very satisfied with his restructuring of the labour force, and even called it his "most significant success". He had divided the labourers according to a grading system. They were graded and paid according to their skills in a system where they started at A1, then moved on to A2, A3, then to B1, B2, B3 or B4. There were also C-level labourers, who were leaders or supervisors and were responsible for, for example, irrigation, vehicles and the workshop.

Within the system, there was also a possibility of being demoted. Those who did not perform their work responsibly or caused "serious social problems, for instance during weekends [...]" could be demoted to a lower grade. However, such incidents were not frequent, according to Hofmeyr, "because of the stigma attached to it". During the previous three years, only two labourers had been demoted. One of them subsequently left the farm. By transferring

${ }^{205}$ Farmers' Weekly, June 7, 1985. 
responsibility to the labourers, Hofmeyr had apparently also transferred the disciplinary control. Those labourers who did not behave according to the rules of the farm were not accepted by the others and consequently left the farm instead. A similar incident occurred on Stols' farm in the Transvaal. After the labourers had elected a committee of three labourers, two of them ordered the third one, who had caused problems and abused his wife, to leave the farm. ${ }^{206}$ Stols did not seem to object to that treatment. In some ways this gave labourers more power over themselves, or rather, they gained power over some areas of their lives, primarily the social areas as it seems. Nonetheless, the new management methods meant that farmers had gained support from the labourers, who saw it as their responsibility to uphold disciplinary rules.

The grading of labourers according to skills and performance was clearly beneficial for motivation, since they would be rewarded for their productivity. But Hofmeyr also had a long-term perspective and explained that he wanted to keep the young men on the farm. In order to accomplish that, he wanted to "create a situation where it is possible for them to earn more than their parents if they become more skilled". The grading system must thus have been designed to favour the younger farm labourers, who could advance in the positions on the farm more quickly than the older generation. It is possible to argue that Hofmeyr and others with similar management methods considered the younger generation more important, and that it would not be as profitable to motivate the older generation to acquire new skills.

This, then, allows us to further analyse the notion of unskilled and skilled labourers. The unskilled labourers were the ones who had been trained through experience of farm labour, which can be called traditional skills. The skilled labourers were the ones who were trained by instructors to operate machinery. These skills were valued higher than the traditional skills because the new machinery represented the latest technology, which was important for the future. The implementation of new machinery thereby also stratified the older generation from the younger one. The younger labourers

${ }^{206}$ Farmers' Weekly, June 7, 1985. 
were chosen to acquire new skills, while the older labourers were discarded and continued to rely on the skills they had acquired through experience. To some extent, the new skills became interrelated with a new generation of farm labourers. Or rather, the implementation of new machinery and the acquisition of new skills created a new generation of farm labourers, which differed from the older generation, which had learned through experience. This can be compared with Karl Mannheim's discussion of generation as a sociological problem. He emphasizes that, in addition to biological age, similar experiences of historical events and social processes, for example from the same class or geographical position, must be included in definitions of a generation as a "social phenomenon". ${ }^{207}$ The skilled labourers clearly had similar experiences of training and work with machinery, which the labourers with traditional skills did not have. To some extent the skilled and non-skilled labourers therefore belonged to different generations, if we speak with Mannheim. In many aspects the two generations obviously also had similar experiences of farm labour, but their position on farms, as skilled and non-skilled, must have created a divide between them in generational terms.

Improving the labour relations on the farm meant that alcohol was not allowed during the working day. The dop system was previously used on Amalienstein, but it was abolished and replaced with a "short service" each morning. Religion thus appears to have replaced alcohol on the farm. It could even be argued that religion was used instead of alcohol to keep the labourers content. Considering the important role of religion for coloured farm labourers historically, it is likely that they favoured a short service every morning. But it is also likely that the farmer thought that religion would help keeping them sober and thereby improve their work. Other transformations accompanied the abolishment of the dop system on the farm: The labourers' houses were improved with running water and the labourers also received irrigated land where they could plant their own vegetables. In order to motivate them to look after their houses and gardens he paid "substantial cash prizes" to those with

${ }^{207}$ Mannheim, 1952, pp. 288-89, 302-04. 
the "neatest houses and gardens". ${ }^{208}$ On Amalienstein the disappearance of the dop system was thus part of the transformed labour relations. It appears that the dop system could not be removed on its own, it had to be accompanied by other changes as well, which had the purpose of motivating the labourers, and to some extent making them feel appreciated. By just removing the dop system without making other changes, it is likely that the labourers would not feel motivated at all, but rather feel that the farmer withheld a gift they considered to be rightfully theirs.

There were different grading systems used in farming. One of the methods was the so called Paterson system, which was based on how much responsibility labourers had. It was described as "practical" by Farmers' Weekly and was "being applied successfully in the Western Cape". ${ }^{209}$ Another system was the piece work system, which was based on the number of vines a labourer pruned, or the amount of grapes harvested during a day. The piece work system could generate "a greater output from workers", but it was important that a labourer had the possibility of "earning a reasonable additional compensation for his improved effort". ${ }^{210}$ The piece work system was thus more based on cash incentives than other incentives such as responsibility and inclusion in the farming operations.

A wine farmer in Tulbagh, Nicky Krone, introduced some of these new ideas in harvesting. In the early 1980s, he started with night harvests since the lower temperature at night meant that the juice content of the grapes was higher. The grapes thus arrived at "the cellar in a much better condition and produce more and better juice". ${ }^{211}$ But the night harvest also improved the productivity of labourers, who did not have to work in the warm sun during the day. The harvest started around 2 am after the labourers had slept for a few hours. In order to be able to see, they used miners' lamps. Although it was dark in the vineyards, there was no risk that the labourers would try to evade work and hide in the dark. The lamps

\footnotetext{
${ }^{208}$ Farmers' Weekly, April 5, 1985.

${ }^{209}$ Farmers' Weekly, June 27, 1986.

${ }^{210}$ Farmers' Weekly, June 27, 1986.

${ }^{211}$ Wynboer, March, 1999.
} 
illuminated the "vine in front of them, so they're not tempted to look around, get distracted and chat to one another", which made supervision easier than during the day, according to a manager on the farm.

The labourers' productivity had improved after they had adjusted to the new sleeping routine. But the labourers were also working under a piece work system, based on a quota for each picking team, "so if a member of a team is not picking his quota, he'll quickly get pulled up by his co-workers". The piece work system had also generated much competition between the teams "as they seek out the heavy laden rows and rush to finish first so they can get first choice of the next spot". ${ }^{212}$ The shift to night harvest was surely innovative, but it is not certain that labourers would have found it pleasing without the piece work system, which enabled them to maximize their income. This, then, shows that the transformation of one aspect of production, such as night harvest, must be accompanied by a transformation of the organization of labour and remuneration, in this case the piece work system, in order to be successful.

However, cash was not the only incentive, which farmers used to motivate labourers. In the mid-1980s, "Spatz" Sperling on Delheim started handing out trophies to the best pickers in addition to cash bonuses. The trophies would be handed out each year, according to Sperling. The trophies went to the men and women who picked most grapes during the season. In 1985, the first year of the award, Frands Arendse and Elisabeth Dreyer won. Both of them picked more than 2,000 baskets of grapes. They were given R50 in prize money and a trophy. Also the second best pickers were given prizes. Gedult Hendriks and Gertruida Ruiten were given R25. The award system, which was novel at the time and became part of the harvest celebration, appears to have improved motivation. In 1985, Sperling expected the harvest to take ten weeks, but it was conducted in only eight weeks. According to Sperling, the "fast picking rate" was an important reason for the quick harvest. There were about 50 pickers involved in the harvest on Delheim. All of them

${ }^{212}$ Wynboer, March, 1999. 
lived permanently on the farm, although some could have been seasonal employees, such as labourers' family members who did not work regularly. Nonetheless, Sperling obviously managed to run the farm with labour that was already on the farm. The awards and money paid to the best pickers perhaps generated better production results than if money was spent on labour from outside the farm, who did not work as fast and accurately as those who were already on the farm. But there had also been "great improvements in the cellar that ensured the harvest was processed more quickly". The award, or similar bonuses, alone was not enough to improve the rate of harvest. The successful farmers knew that investments in all parts of the production process were necessary in order to improve production.

The winners of the trophies at Delheim were fairly young, but those who came second were old. Hendriks had been on the farm for 30 years and Ruiten had been there for 25 years. Winning awards and prize money was clearly not only motivation for the young generation of farm labourers. Also the older ones were able to perform well. The prize money was of course desired by the labourers. The R50 to the winners equalled a monthly wage in 1975 and probably close to the same in 1985 . But also the others were given a "picking bonus for every bushel basket of grapes they pick". ${ }^{213}$ Trophies and prize money were thus only an addition to the standard bonus, but nonetheless desirable. More importantly, though, Sperling had managed to turn work into a competition. Labourers, who were already competing with each other over employment, and picking bonuses, were further motivated to compete against each other for trophies and prize money. The labourers who won surely experienced pride in their work and were perhaps regarded as successful by their fellow labourers. But since work had turned into competition, they were also competing for the praise from the farmer instead of regarding him as a person, who exploited their labour. Instead of paying attention to relations of exploitation between farmer and labourer, they were thereby encouraged to focus more on the relationship to other workers, that

${ }^{213}$ Wynboer, May, 1985. 
is, their capability to work well in relation to others. This was the essence of the transformation taking place in labour relations during the 1980s, when farmers found new ways of improving labourers' output.

\section{Productivity, profits and stratification of the labour force}

The improved methods of management and production during the 1970s and 1980s were to some extent a result of lowered profit levels. In table grape farming in the Western Cape, wages were the "biggest cost item" for farmers, and constituted about one third of input costs. On Freddie Kirstens' farm Vredenhof in Paarl, wages had increased 19.6 per cent between 1975 and 1982, which was more than any other input cost, compared to an increased gross income of only 11.8 per cent during that period. Kirsten stated that a farmer had to increase labour efficiency on his farm by 8 per cent each year in order to be able to make profits. Labour was the only cost that the farmer had control over, according to Kirstens, and the farmers therefore had to "use this opportunity to the full". ${ }^{214}$ Clearly, farmers controlled also other costs, such as investments in land and irrigation, but what Kirstens probably meant was that labour was the only factor which could most easily be made more efficient. Machinery produced at a certain rate per hour and could only be more efficient if the technology itself changed, while labourers could produce more under the right conditions. Therefore, farmers had the greatest opportunity to increase profits by improving labour productivity. And they could accomplish it rather easily if they adopted the new management methods, which were not mainly based on paying higher wages, but on motivating the labourers and grading them into categories.

Farmers had to improve the efficiency of labourers continually. But it was important to acknowledge that all labourers had different productivity levels, both in "quality and quantity". Productivity could of course be increased by only hiring the most productive labourers and fire the less productive ones, but this was not recommended. It was more "preferable to increase the efficiency of

${ }^{214}$ Farmers' Weekly, June 27, 1986. 
less productive workers than to leave them jobless". But since all labourers had different productivity levels, farmers were recommended to introduce salary scales, which recognized the differences. In other words, those labourers who were more productive should be paid higher wages. Apparently, there had been cases where no such differentiation had been made, with the result that the more efficient labourers had resigned while the less efficient ones had stayed. ${ }^{215}$ That was definitely not what farmers wanted.

Since farmers had to struggle to keep labourers on farms, it was obvious that the position of farmers was weakened during the mid1980 s along with the weakening of the apartheid state. The new management methods were thus not only caused by lowered profit levels, but because the state structure, which had previously favoured farmers, no longer guaranteed labour at a low cost. The power of white farmers as a class was to a great extent based on apartheid, and when the state structure was not able to keep labourers on farms, the farmers themselves had to find ways of keeping them there. This was of course a challenge for some farmers, who previously had been able to rely on the state for a supply of labour.

By retaining the educated and skilled labourers, farmers could in fact also save money. On "Spatz" Sperling's farm Delheim, the mechanic, Gregory Claasens, had invented his own wire crimper to produce supporting wires for trellising. The wires could be purchased at $40 \mathrm{c}$ per metre and "cost farmers a tidy sum each year", according to Farmers' Weekly. By producing the wires on the farm, large sums could be saved. The wires produced on Delheim were made from standardised, galvanised wire purchased at $20 \mathrm{c}$ per metre. Claasens had produced the crimper machine from "scrap cogs, wheels and plate-metal", apparently found on the farm. The entire process of producing the supporting wires was conducted on the farm. ${ }^{216}$ Three labourers worked with the machine and could crimp 30 metres per hour. During an eight-hour day, 240 metres of crimped wire could thus be produced, at the cost of R48, excluding labour. To purchase support wires from producers would have

\footnotetext{
${ }^{215}$ Farmers' Weekly, June 27, 1986.

${ }^{216}$ 'Farmers' Weekly, Nov. 28, 1986.
} 
nearly doubled the cost. The saving made in just one day on Delheim would almost have been enough to hire a labourer for one month; the R48 equalled a black labourer's monthly wage in Stellenbosch in $1975 .^{217}$ Inventions such as the one constructed by Gregory Claasens could therefore prove very valuable to the farmer, who could spend money elsewhere, for example on labour.

The changes in management and training for the labour force thus contributed to a stratification of the labour force. The skilled labourers were paid higher wages, and if they trained further they had the opportunity of earning even more. But they were also encouraged and motivated by the farmers to be more productive through more communication of what each individual labourer was expected to do on the farm. The younger farm labourers were most likely the ones who were favoured by farmers to acquire training. It was important for farmers to ensure that the younger generation stayed on the farm so that labour reproduction was secured and that the future labour force was skilled appropriately for the farming ventures.

It appears that it was easy to remove the tots of wine to these labourers, as long as they were given training, encouragement and higher wages instead. But there were also those labourers who were not as productive as farmers expected them to be. The less productive labourers most likely received less training and did certainly not acquire as many skills as the productive labourers who became more skilled as tractor drivers, mechanics or irrigation or pruning specialists. At least two distinct categories of farm labourers thus appeared during the 1980s: the skilled and the non-skilled. To some extent they belonged to different generations although not necessarily different age groups. The skilled labourers became the core of the farm labour force, while the non-skilled ones probably took on a more peripheral position that was more in demand during harvest season than throughout the year. But as we have seen, it was not recommended to fire the less productive labourers. Instead it was better to improve also their productivity. However, they would be paid lower wages than those who were more pro-

${ }^{217}$ See Agricultural census 1975, pp. 73, 93. 
ductive and in the end it was not profitable to have labourers who were not productive. It is likely that these less productive labourers joined the seasonal labour force, especially when more machinery was implemented.

On farms such as Amalienstein the labourers did not seem to object when the tots of wine were no longer given. But the labourers who were less productive and did not benefit from the new management style and grading system might have been more inclined to move to farms, where they could receive tots or perhaps to cities where wages were higher. Therefore, the two categories of farm labourers that appeared during the 1980s were stratified in a way that had not been seen before on farms. Both these categories continued to drink heavily, though. But those who constituted the core labour force had more incentives to drink less, at least during the week and not to the extent that it affected work. The methods advocated by Arnold Mol, for example, would mean the end of "Monday morning absenteeism". ${ }^{218}$ Surely, Mondays continued to be the worst day for farm labour even after the $1980 \mathrm{~s},{ }^{219}$ but it is possible that such problems were reduced after the implementation of new management styles.

However, the new management styles and improved labour relations were not just caused by increased demand on productivity. Such changes were regarded as necessary if farmers wanted to remain in control of their farms. In the next chapter, we will therefore look more closely at how the changing social climate in South Africa during the 1980s affected practices on farms.

\footnotetext{
${ }^{218}$ Farmers' Weekly, June 7, 1985.

${ }^{219}$ Petrus Bosman, Bosman Family Vineyards, interview, 2013-12-10.
} 


\section{TRADE UNIONS, SANCTIONS AND IMPROVED CONDITIONS ON FARMS}

\section{Getting the house in order - trade unions are coming to the farm}

During the 1950s and 1960s, the KWV cared little about labour relations and conditions on farms. That matter was instead left to the individual farmers. But in the late 1970s they had a new approach. In 1979, the KWV annual report mentioned labour relations for the first time, when it stated that "[a] healthy, happy labour force on our wine farms benefits rural employment and this retards the movement to the cities."220 The migration to urban areas, which had been one reason for the new management methods, was obviously also seen by the KWV as something that threatened the entire wine industry. Further, the chairman of the KWV wanted to "advance the thesis that if the wine industry enjoys stability and progress, the Western Cape will have a firm foundation upon which to build the prosperity of the region". ${ }^{221}$ The stability must have meant both that labourers stayed on the farms continually so that labour reproduction was secured and that the labourers did not have reasons to complain about the conditions on farms. This notion was shared by others in South Africa, even at the government level, and a Manpower Commission was appointed in 1982 to investigate labour relations in farming and domestic service.

\footnotetext{
${ }^{220}$ KWV Annual Report, 1979, p. 1.
}

${ }^{221}$ KWV Annual Report, 1979, p. 1. 
Mayson has described how the Rural Foundation was a crucial force in the transformation of labour relations on fruit farms in the Western Cape. The work of the Rural Foundation was certainly significant, but it is important to emphasize that there were also internal forces on farms that actively sought to transform labour relations. The Rural Foundation was in fact based on strategies already adopted by farmers in the Western Cape. According to the National Manpower Commission, there had in "agricultural circles" for a long time "been a need to co-ordinate [...] the many successful programmes of individual farmers for the development and therefore the improvement of the quality of life (economic, social and physical) [...]" of the farm labourers. These programmes were introduced to other farmers in 1982 when the Rural Foundation was established by organized agriculture "[o]n the basis of the successful working results obtained by certain farmers in the Western Cape [...]”. ${ }^{222}$ The farmers in the Western Cape, many of them wine farmers, were apparently at the forefront of the improvement of labour relations in South Africa and served as models for others. The Rural Foundation picked up some of these initiatives started by the Western Cape farmers and spread them to others.

Housing for farm labourers was one important aspect of improvement of conditions on farms. On Kanonkop in Stellenbosch, the Krige family built their "first proper housing component" in 1973. There had been houses on the farm before that, but they were probably "not up to standard". After 1973, however, "all the labourers on the farm got housing, water, electricity, sanitation, the lot". Johann Krige is not certain, but thinks that in the wine regions, Kanonkop was "one of the first producers to build proper housing for all the labourers". That was certainly a big investment at the time, but it secured labour and improved the reputation of the farm. The houses have been maintained since the 1970s and labourers have not paid any rent and they have also received water as part of the wage. The point in time when the houses were built is significant. 1973 was the year when the wine of origin system was established, and two years after the wine route had started,

\footnotetext{
${ }^{222}$ Report of the National Manpower Commission, 1983, p. 261.
} 
which appears to have had an impact on the accommodation for labourers. Kanonkop was not part of the wine route, but it is likely that the Krige family still wanted to be a part of the new trend with tourists coming to the farm for tastings. Those farmers who wanted to attract tourists to the farm also had to ensure that the living standard for labourers was, at least seemingly, acceptable.

Attracting tourists to farms could thus be one reason why some Western Cape farmers were earlier than others to start improving conditions on farms. The process of improvement could have spread from the large estates to other farmers, who wanted to follow their example and make profits from tourism. However, compared to the rest of country, conditions in the Western Cape were not necessarily worse than in other places. Wages, for example, were higher in the Western Cape than the average for the country, much because of the coloured labourers, who earned more than black labourers. ${ }^{223}$ But the dop system, and alcohol related problems, probably contributed to deteriorated social conditions on farms. Therefore, it was logical that farmers tried to improve conditions in order to be more profitable and keep the labourers on the farms. According to Mayson, the initiative to improve conditions on farms in the Western Cape came in the late 1970s from students in Stellenbosch, who went around to the farms and talked to farmers and labourers in an effort to uplift the farm labour force socially. The farmers did not object to the intervention by these student organizations, ${ }^{224}$ suggesting that also farmers realized that there was a need for social upliftment and change on their farms.

It is even easier to understand why farmers accepted this intervention if we regard the social changes in South Africa during the 1970s and early 1980s. In 1973, large-scale strikes were undertaken by industrial labourers in Durban. These strikes spread to other parts of the country and initiated resistance against the apartheid government on a wider scale. The strikes coincided with a wave of intellectual radicalism, which focused the relationship between apartheid and capitalism. Further, in 1976 the Soweto uprising also contributed to a wave of protests against the apartheid govern-

\footnotetext{
${ }^{223}$ See Marcus, 1989, p. 181.

${ }^{224}$ Mayson, 1990, p. 104.
} 
ment in South Africa and abroad. The protests continued after 1976 and gave the trade union movement increased strength. A commission led by Nicolaus Wiehahn was appointed to investigate labour relations in industry, and recommended in 1979 that also black trade unions should be accepted for collective bargaining. The black trade unions subsequently received recognition, which fundamentally changed labour relations in industry. ${ }^{225}$ Agriculture was more or less outside of the industrial labour conflict, but the Wiehahn commission recommended that also trade unions in agriculture should be included in the labour legislation. The apartheid government did, however, not agree. Instead, it appointed a $\mathrm{Na}$ tional Manpower Commission to investigate labour relations in agriculture further. But its report was never made public, probably, as Dawie Bosch argues, because its recommendations were opposed by farmers' organizations. ${ }^{226}$ During the 1980 s, farm labourers were, however, not prohibited to form unions, but they were not recognized for collective bargaining, which meant that the bargaining power of farm labourers was individual. Farmers and farm labourers therefore still relied on personal relations to a great extent. Those conditions definitely corresponded to the new management methods, which individualized labourers.

However, the increased trade union activity and power for black trade unions functioned as a warning to farmers. Unless conditions on farms were improved, the farm labourers would be attracted by the unions as an instrument for accomplishing change. In the 1980s, the editorial in Farmers' Weekly was involved in such a debate and urged that "[f]armers who still believe that [farm] workers will not be influenced by recent events in the industrial labour market should wake up". ${ }^{227}$ The arrival of unions into farming was apparently seen as inevitable by the farmers' representatives. Although their viewpoint was that farmers and labours themselves were the ones who knew best what labourers needed, they were re-

\footnotetext{
${ }^{225}$ Beinart, 2001, pp. 237-42, 246. For discussion on the impact in industry, see for example Webster, 1985; For the relationship between apartheid and capitalism, see Wolpe, 1980.

${ }^{226}$ Bosch, 1991, p. 52.

${ }^{227}$ Farmers' Weekly, Aug. 23, 1985.
} 
alistic and argued that farmers had to have a strategy for when the unions were coming.

In the mid-1980s, the South African Agricultural Union took precaution to guarantee that farmers would not "be caught napping in the fast-changing labour climate". ${ }^{228}$ The trade unions in industry were active at the time and there was "every likelihood that these influences will reach farm workers in the not-too-distant future". ${ }^{229}$ The struggle in industry, and increased trade union activity there, created awareness in the South African Agricultural Union. It realized that unions could gain influence also on farms and that preparations were made by unions to organize farm labourers. The Agricultural Union had "recognised the need to investigate and establish the necessary machinery to deal with possible future developments to the benefit of both parties". ${ }^{230}$ That machinery would obviously consider the demands of both farmers and labourers and the Rural Foundation could play an important role in this regard. According to Farmers' Weekly, the Rural Foundation could "serve as a meaningful forum for negotiations between employers and employees". If the Rural Foundation was used for that purpose, it could even "eliminate the need for a trade union". 231

The demand for a strategy for farmers to handle unions suggests that only a portion of the farmers had done so in the mid-1980s. But there were obviously those who had, especially those involved in the Rural Foundation, which primarily meant the Western Cape farmers. According to Mayson, the Rural Foundation was involved in providing information to farmers for how to handle trade unions on the farms. ${ }^{232}$ The strategy to handle unions was clearly aimed at improving conditions socially and economically for the labourers. But equally important was to improve communication between farmers and labourers, usually through committees of farm labourers. During the 1990s, unions such as Food and Allied Workers Union (FAWU) managed to organize some labourers on

\footnotetext{
${ }^{228}$ Farmers' Weekly, Aug. 23, 1985.

${ }^{229}$ Farmers' Weekly, Aug. 23, 1985.

${ }^{230}$ Farmers' Weekly, Aug. 23, 1985.

${ }^{231}$ Farmers' Weekly, Aug. 23, 1985.

${ }^{232}$ Mayson, 1990, p. 150.
} 
farms in the Western Cape, although it was only a limited number. However, the unions were not used as mechanisms for increasing the labourers' power relative to the farmer. Instead, the labourers used the unions to improve the farms in various ways, which means that the unions functioned in a manner similar to the committees. The reason for this, according to du Toit, was that the farm labourers were still influenced by the paternalist structure on farms, and that the arrival of unions did not change the fundamental relationship between farmers and labourers. The farm labourers did not regard the farmers as belonging to an opposing class, which exploited them. Instead, they regarded themselves as belonging to the family on the farm, and the union was simply one way of improving the farm. ${ }^{233}$

$\mathrm{Du}$ Toit argues that the paternalist structure on farms affected the farm labourers, who could not act outside of the discourse on farms. Surely, that could have been the case, but the point to make here is that these notions were evident among farmers and their representatives already during the 1980 s, when they realized that trade unions could be a threat in the future. In 1986, the editorial in Farmers' Weekly again discussed the issue of unions in farming. It stated that although it was better if farm labourers stayed outside of the Labour Relations Act and if trade unions were not involved, farmers had to be prepared for the new political situation in the country. Therefore it was important that the South African Agricultural Union developed a relationship with the trade unions. It already had a "useful working relationship" with commerce and industry and "can prepare a plan to also do so with a trade union in certain respects". The most crucial issue was to make the union "acutely aware of the fact that when farming suffers, farm labourers' jobs are the first on the line". By telling the union that labourers would become unemployed if their demands exceeded what farmers were prepared to agree to, the farmers seemingly hoped to form an alliance with them. This cooperation could be structured in different ways, but Farmers' Weekly even suggested that the unions should be involved in farming: "However difficult it might be,

${ }^{233}$ Du Toit, 1993, pp. 329-31. 
union leaders could be encouraged to attend and participate in certain farmers' meetings." Such inclusion would probably be seen as a success by the trade unions, which in turn could be used by the farmers, since the unions "might even be persuaded to offer their support to the farmers' cause". ${ }^{234}$ If such a strategy was accomplished, the farmers would manage to have the unions and the unionized labourers on their side regarding the overall aim of a profitable industry.

The farmers clearly preferred no unions at all, but since they could not control the political situation any longer, it was definitely better to try to negotiate with the unions and gain their support while they still had the upper hand. After the fall, or at least serious decline, of the apartheid system, which appears to have been expected by the farmers' representatives in the mid-1980s, it would be harder for the farmers to control negotiations with unions. By discussing with them, and to a great extent setting the agenda, farmers would be able to minimize the influence of the unions in the future. As Farmers' Weekly argued, this was not a "betrayal of the farmers' beliefs or values. It is an agreement to make common cause on issues which threaten both groups, while agreeing to differ on other matters. It is simply sound tactics." ${ }^{235}$ In the Western Cape, this strategy had clearly been implemented by the 1990s, since the farm labourers in unions were more interested in the success of the farm than in restructuring labour relations. The transformation of paternalist structures on farms in the 1990s, which were based on inclusiveness, ${ }^{236}$ can therefore also be explained as a result of decisions taken in the previous decade, when farmers could control how the unions should be handled. By simultaneously improving conditions on farms, which included phasing out the dop system, they were beginning to get their house in order, and had - unlike industrial capital - managed to avoid the threat from unions.

\footnotetext{
${ }^{234}$ Farmers' Weekly, March 21, 1986.

${ }^{235}$ Farmers' Weekly, March 21, 1986.

${ }^{236}$ See Du Toit, 1993.
} 


\section{Keeping politics away from farming}

The measures taken by farmers and their representatives during the mid-1980s to hamper trade union organization appears to have been successful. In 1990, Andrew Ball argued that "organizing the farmworkers will be extremely difficult" and that those who had tried previously did not have a "clear strategy". ${ }^{237}$ However, wine estates were described as one sector with a "high-profile public image", where unions should focus attention for making inroads into agriculture. Also co-operatives were considered to be good starting points, since co-operatives processed agricultural products and thereby were covered by labour legislation. ${ }^{238}$ It is quite possible that estate owners and others in the wine industry were aware of this and acted accordingly to prevent being targeted by unions.

During the late 1980s, the KWV acted on the ideas discussed by organized agriculture. In 1988, it suggested that labour relations in the wine industry always had been good and that they were "based on mutual respect", which was surely how the KWV wanted to portray the wine industry. It was probably not a view shared by most labourers, although they had not protested against conditions publicly. However, in order to continue such relations, the organization "agreed to offer a consulting service with regard to labour relations and personnel management to co-operative cellars and wine producers". The demand for such a service came from the Co-operative Wine Cellars Committee, and it thus included both co-operatives and estate producers. But it appears that the relations in the wine industry were not as good as the KWV claimed; according to the KWV, the purpose of the service was to establish a "basis for healthy long term relations", which means that such had not existed previously. Initially, it would focus on finding areas where conflicts might occur and then find a strategy for the "elimination of such areas". ${ }^{239}$ In short, the service was meant to provide an aid for farmers and cellar producers in their negotiations with unions. This indicates that both farmers and the KWV realized that there were certain "areas of possible conflict" and that the labour-

\footnotetext{
${ }^{237}$ Ball, 1990, p. 53.

${ }^{238}$ Ball, 1990, pp. 57, 60.

${ }^{239}$ KWV Annual Report, 1987, p. 8.
} 
ers would be attracted by the unions unless they were improved or even eliminated. The dop system was probably one of those problems and it is likely that farmers were encouraged to get rid of that practice.

The fact that the KWV provided a consultation service focused on labour relations demonstrates that the farmers and cellar producers regarded unions as a problem that they were not equipped to handle on their own. South African farmers in general had no experience of it since the ICU was active in the 1930s. It was therefore a new situation for them when they no longer could control all the labourers and had to negotiate with unions. The KWV itself also had to deal with unions, though, and could set an example for others in the industry. The organization "had its first negotiations with a trade union in 1987", which apparently "went smoothly" and resulted in "the implementation of extremely successful personnel practices". ${ }^{240}$ It is unclear how the negotiations with the union could result in such a positive outcome already during the first year. The KWV most likely described negotiations in those terms in order to spread the union-friendly attitude to the farmers and others in the industry. Still, in 1987, the KWV had adopted a strategy to handle the new political situation, which would spread throughout the industry.

During the following years, the consultation service, which was offered to co-operative cellars and estates, was utilised and had "made a considerable contribution to stabilising manpower practices". It was only cellars that negotiated with trade unions, though, since unions were not recognized for collective bargaining at the estates. But among the co-operative cellars, a considerable number negotiated with unions; in 1989 there had been agreements between 23 of the co-operatives and a union, which was "actively recruiting members at the co-operatives". ${ }^{241}$ Organizing labourers at co-operatives was a conscious strategy by the trade union movement, since the co-operatives were processing, not producing, agricultural products and were therefore not exempt from labour

\footnotetext{
${ }^{240}$ KWV Annual Report, 1987, p. 8.

${ }^{241}$ KWV Annual Report, 1989, p. 5.
} 
legislation. $^{242}$ That strategy appears to have improved the level of organization in the co-operative cellars, but not on the farms. In the late twentieth century, the degree of unionization among labourers in co-operative cellars was 95 per cent, according to Joachim Ewert and Johann Hamman, which demonstrates that the cellar producers were not able to keep unions out in the way that farmers could. On wine farms the unionization level was about 7 per cent at the same time. Ewert and Hamman suggest that the "industrial nature of the labour process" in the cellars could explain why labourers there were unionized to a much greater extent than on the farms. But they also indicate that the racial composition of the labour force in cellars was different than on the farms. Most labourers in the cellars were black, who were more inclined to unionization than the coloureds, who dominated on the farms. $^{243}$

The comparatively high unionization level in the cellars already during the 1980s, when unions were not recognized for collective bargaining on farms, gives further evidence to the thesis that the industrial nature of the process was more important for the level of unionization, although the racial composition of the labour force should also be regarded as important. Considering the comparatively high unionization level in the co-operative cellars, it is, however, apparent why the cellars were eager to obtain a labour consultation service from the KWV in the 1980s.

During the late 1980s, the KWV, in conjunction with the Rural Foundation, went further than providing a consultation service. In 1989, an agreement was made that the Rural Foundation "would develop a manpower code for the wine industry". ${ }^{244}$ Previously the KWV had focused on the co-operatives and it was therefore seen as a "logical step" to give more attention to labour conditions on the farms, the so called primary producer level. The work with improvement would be far-reaching and encompassing; in 1990, the Rural Foundation would cooperate with producers throughout the wine regions "in order to gain the widest possible participation and

\footnotetext{
${ }^{242}$ Ball, 1990, p. 60.

${ }^{243}$ Ewert and Hamman, 1999, pp. 212, 216.

${ }^{244}$ KWV Annual Report, 1989, p. 5.
} 
support for the manpower code and a set of guidelines for personnel practices". 245

The work with improving relations on farms had been going on and had been prioritized for a "considerable period" by 1989. In the three previous years, the KWV had established contacts with farmers, co-operatives and the agricultural union and discussed the most efficient ways to assist producers "with regard to manpower management". ${ }^{246}$ Apparently, the KWV regarded it as necessary to reach all the farmers, which means that there were problems on the farms, which could potentially threaten the entire industry. Although we have seen that some farmers started to improve conditions during the 1970s and 1980, that trend was not visible on all wine farms. Improvements in labour conditions had primarily been made on the estates and large farms in and around Stellenbosch. In the more peripheral areas, where farmers relied on sales to cooperatives, there were probably few who had conducted changes on their farms. The farmers who relied on co-operatives were also the absolute majority, and were responsible for the largest share of wine production. These farmers were thus important for the wine industry and had to be included in the process of change in labour conditions.

While the KWV wanted farmers to improve conditions on farms, the organization ensured that it would not be at the expense of changed power relations. The structure that had enabled farmers to hire cheap labour, be exempt from labour legislation and give labourers wine, as well as the increasing opposition to the conditions in the country, would thus not be included in the KWV's official policy documents: "Caution will be exercised to ensure that this code will only concentrate on manpower matters and not fall into the trap of dragging the country's politics into the work place." 247 In order to improve conditions without changing relations on farms, the KWV thus explicitly argued that politics and labour relations in farming must be kept separated. This was in fact the central issue behind the improvement on farms. If farmers were to re-

\footnotetext{
${ }^{245}$ KWV Annual Report, 1989, p. 5.

${ }^{246}$ KWV Annual Report, 1989, p. 5.

${ }^{247}$ KWV Annual Report, 1989, p. 5.
} 
main on the land, they had to ensure that discussions about farming and farm labour was not conducted in the political sphere. That was perhaps the most important reason why health issues and recreational facilities constituted a central part of the Rural Foundation's recommendations to farmers. Such issues, which included the dop system and alcohol related problems, were seemingly nonpolitical. By focusing on those issues, farmers could portray themselves as interested in the well-being of the labourers and their social upliftment without having to involve themselves in discussions about land ownership, labour legislation and, of course, apartheid itself, which guaranteed white farmers a dominant position in relation to the labourers. If the discussion had been focused on wages or land ownership, the farming sphere had been impossible to separate from the political sphere.

The new strategy was important for the industry as it set guidelines for all farmers to follow. But much had already been done, according to the KWV. In 1990, the KWV argued that the new manpower code was initiated in order to "reinforce the excellent relations between employer and employees" in the wine industry, but also clarified that "[c]onsiderable progress has been made with the improvement of the labour conditions and quality of community life of farm workers in the past few years". One example of this was the use of the dop system, which was described as an "undesirable practice" by the KWV. The KWV referred to a survey by the Rural Foundation among its members, which showed that the dop system was only "found" on 2 per cent of the farms in the Western Cape. ${ }^{248}$ That could of course mean that it existed on more farms, but was not found by the Rural Foundation. Research from the 1990s indicates a more widespread use of the dop system, ranging from about 10 to 20 per cent of farms. The definition of the dop system probably affected the degree to which both farmers and labourers reported its use. For example, if it was defined as use of wine as wages, the dop system would be less frequently reported than if the question was if labourers were given wine on their farm, which could include nights and weekends. ${ }^{249}$

\footnotetext{
${ }^{248}$ KWV Annual Report, 1990, p. 4.

${ }^{249}$ See London, 1999, pp. 1409-10.
} 
However, the numbers presented by the Rural Foundation, seen in relation to those presented by various researchers, clearly shows that the use of the dop system was significantly reduced by the early 1990s compared to the 1970s and early 1980s. None of the eighteen farms visited by Schärf had abolished the dop system altogether. However, it is not clear if the wine was part of the wages or given in addition to wages. For example, overtime work was usually paid with wine and was regarded as voluntary by "most farmers", who voluntarily gave wine to the labourers. ${ }^{250}$ In 1984, the giving of wine to labourers was widely practised in Stellenbosch. Hans Steyn describes that the system was not a "thing of the past". The wine was not part of wages as it seems, but the "practice of giving free drink on the farms is still very frequent in the Stellenbosch area". More than 40 per cent of the labourers interviewed reported that they were given free drink on the farms they worked on. ${ }^{251}$ The crucial period for the decrease of the dop system was thus the 1980s and early 1990s when farmers started to change practices on farms. By doing so they managed to keep politics out of farming.

It is also noteworthy that 1990 was the first time the KWV publicly denounced the dop system, at least in its annual reports. Previously the KWV had encouraged farmers to improve conditions, but not explicitly stated that the dop system was undesirable as a practice on farms. It is thus clear that recommendations from the KWV did not cause the demise of the dop system. During the 1950s, the organization had not endorsed its removal, quite the opposite; it had argued that the dop system was advantageous to both farmers and labourers. ${ }^{252}$ During the following decades the KWV had not endorsed it publicly, but not condemned it either. The KWV was surely caught between two worlds on the issue. On the one hand, there were concerns about conditions on farms from organized agriculture and supporters of the Rural Foundation, although no direct opposition to the system. On the other hand, there were farmers who continued to use the system and relied on it for

\footnotetext{
${ }^{250}$ Cf. Schärf, 1984, p. 155.

${ }^{251}$ Steyn, 1984, pp. 2, 5-6.

${ }^{252}$ See Select Committee on the Subject of the Liquor Bill, 1952, p. 302.
} 
their labour supply. The KWV did not want to oppose either of those two groups, since it relied on support from the government, but also the support of the members, the farmers. In view of that situation it is easy to understand why the KWV did not condemn the practice until 1990, when it was more or less eradicated or at least significantly reduced in importance. By 1990, it was uncontroversial to call the dop system undesirable.

In order to implement the manpower code, a Manpower Development Advisor was appointed by the KWV in 1990. The advisor was stationed at the Rural Foundation in Stellenbosch and apparently worked at a fast pace. Already the following year, in 1991, the "introductory and informative phase of the Manpower Code [was] virtually completed". ${ }^{253}$ Farmers had thus been informed about the code, and what was expected of them. But many had also begun to implement it and thus also realized its importance. In 1992, the chairman of the KWV, Pietman Hugo, reported that 95 per cent of the wine industry had signed the manpower code. The remaining 5 per cent would do so in the near future, he thought. Those who had signed the code were 72 of 74 estates, 70 of 72 cooperatives and 70 of 76 private producers. Since most of the farmers belonged to a co-operative, they had thus not signed the code themselves; it was the co-operatives that signed and therefore it was their responsibility to ensure that farmers complied with the code. Still, the support for the manpower code was widespread. Hugo stated that the code was "'a declaration of intent to maintain manpower practices which fully comply with modern day industrial requirements"'. ${ }^{254}$ Although most of the farmers were only producers of grapes, and not producers of wine, the KWV was obviously aware that the relations seen in industry would become a reality in farming in the near future. Therefore, labour rights issues such as the "right to reasonable remuneration and service benefits", "the right to the establishment of opportunities for negotiation and bargaining [...] by providing communication channels [...]" and the "right to freedom of association" were included in the code along with rights to health and safety protection and hu-

\footnotetext{
${ }^{253}$ KWV Annual Report, 1991, p. 7.

${ }^{254}$ Wynboer, May, 1992.
} 
mane living conditions. ${ }^{255}$ The code did, however, not mention the dop system. It was clearly up to the farmers themselves to decide on the practical implications of the code.

In 1992, the advisor had continued working with farmers and even set up workshops at 61 cellars and given lectures to farmers' associations. The KWV was convinced that the work of the advisor would help to ensure that farmers were "prepared and informed to handle changes that are taking place confidently". ${ }^{256}$ The changes referred to were obviously the unbanning of the ANC and talks of a negotiated settlement in South Africa, which would mean that the white minority rule was soon coming to an end. In order to prepare for that, the farmers realized the urgency in implementing new labour practices.

The threat of increased trade union influence in farming during the 1980s can thus explain the decreasing use of the dop system to a great extent. Increased productivity was clearly also a reason for changing practices on farms, which many of the wine farmers accomplished already during the 1970s, and which was successful. The improved conditions cost farmers money if they paid higher wages, improved housing and invested in training for their labourers, but it also generated income in the form of higher productivity. But such measures did not change the fundamental power structure on the farms; instead it reinforced farmers' position. The establishment of unions would threaten the existing power relations to a greater extent. Those farmers, who had not improved conditions during the mid-1980s, were therefore probably more inclined to do so when the unions started becoming active also in farming.

The Rural Foundation was an important actor in this regard, since it promoted social upliftment for the farm labourers on a wide scale. But it is clear that not all farmers had to be told by the Rural Foundation what had to be done. Jannie Bosman on Bosman Family Vineyards explains that his farm was never involved in the Rural Foundation. Instead they did their "own thing” on Bosman. During the 1980s, the Bosman family owned two adjoining farms. Conditions there were good, according to him. However, a third

\footnotetext{
${ }^{255}$ Wynboer, May, 1985.

${ }^{256}$ KWV Annual Report, 1992, p. 8.
} 
farm, owned by a neighbour, was located in the middle of the two farms. Bosman notes that conditions on that farm were not good and explains that the farm labourers there were "neglected" and disadvantaged compared to the labourers on his own farm. Alcohol problems were also significant.

When Jannies Bosman took over as owner on Bosman, his father, who was previously in charge, advised him to purchase the neighbouring farm and incorporate it into the business. His father told him that he had to do it, not because the neighbouring farm was valuable or because it could generate profits, but because if he did not, it would destroy the other two farms. In other words, there was a risk that the labourers on the Bosman farms would be influenced by the people on the neighbouring farm and that the social problems there would spread. Even though the labourers on the family's original two farms were perhaps not without problems, Bosman's account clearly shows how farmers with money could act in order to solve problems with alcohol abuse and poor social conditions. At least according to himself, Bosman bought the neighbouring farm and tried to uplift the people who lived there, since he wanted to continue to farm successfully. ${ }^{257}$

Farmers such as Bosman did thus not rely on the Rural Foundation. They knew that by improving conditions, they invested in the labour force and thereby also in the farm. Better social conditions was, in short, good for business.

\section{The impact of sanctions}

Despite the success of the Stellenbosch wine route, increased profits for the KWV and the transformation of the wine industry to production of quality wine, many wine farmers were suffering during the mid-1980s. The weak Rand and increasing debt resulted in a financial crisis, which affected the farmers who could not export products, and had to pay high prices for imported farm implements. Pietman Hugo, chairman of the KWV, announced in 1986 that poor exchange rates, high interest rates and high inflation, which farmers had not been prepared for, had resulted in "increas-

\footnotetext{
${ }^{257}$ Jannie Bosman, Bosman Family Vineyards, interview, 2013-12-10.
} 
ing input costs". According to Hugo, suppliers of implements kept their profit levels up by passing on costs to buyers, which meant that farmers had to pay more for their implements. Farmers in turn had to expect lower profit margins since they were not allowed to determine wine prices based on input costs. In 1986, there had been pleas from all the wine districts to increase wine prices during 1987 to "help stem the financial landslide wine farmers, particularly young farmers, were experiencing". ${ }^{258}$ This crisis was apparently difficult for many farmers, who had been unprepared, but it was not the only thing that they had to worry about.

Increasing international opposition against apartheid during the 1980 s affected wine farming and the agricultural sector in general. Scandinavian countries and Ireland banned imports of agricultural products from South Africa, but this was not something that worried farmers' representatives. The U.S. decision to ban imports of South African agricultural products was, however, regarded as more detrimental to agricultural production. Kobus Jooste, the president of the South African Agricultural Union, sent messages to members of the Agricultural Committee of the U.S. senate in an appeal for the U.S. not to support the extended boycott of South Africa. He pointed out that the commercial agricultural sector in South Africa employed over a million people with more than five million dependants and that sanctions would affect both farmers and labourers and their dependants. ${ }^{259}$ Sanctions had "already caused the demise of several export industries with disastrous effects in agriculture", according to Jooste. Fruit farmers were perhaps those worst affected. The sanctions meant that they could not export their early fruit to markets at profitable prices due to airfreight charges. ${ }^{260}$

Boycotts on agricultural products meant that farmers lost export markets. In order to combat the effects of sanctions, the internal South African wine market had to be developed. The trend of lowered wine sales domestically was therefore worrying, according to Hugo. Increased cooperation between farmers and marketers was

\footnotetext{
${ }^{258}$ Farmers' Weekly, Nov. 7, 1986.

${ }^{259}$ Farmers' Weekly, Oct. 17, 1986.

${ }^{260}$ Farmers' Weekly, Oct. 31, 1986.
} 
consequently necessary. One solution offered by the KWV was to develop new "trade-name products and new markets as opportunity allowed". ${ }^{261}$ The KWV's marketing director, Kobus van Niekerk, stated that the sanctions would have little effect on wine in South Africa. He mentioned that local markets were considered as more important than the export markets in all wine producing countries, including South Africa. According to van Niekerk, the South African wine industry had "enough financial, research and product-development power to develop and promote suitable products for this purpose". Apparently, there had been many developments during the previous years in local wines and marketing of wine. However, sanctions could have a negative impact, since the exports were "the display window of South African quality to the world". The sanctions would therefore mean that South Africans would not be able to compete on the international wine market. South African wine farmers were perhaps worried that this would lower their profits, but such worries were unfounded, according to van Niekerk, who argued that "sanctions would have little effect on the local wine industry" financially. ${ }^{262}$ The statements by the KWV could obviously have been a strategy to keep appearances up, since the international market was important, although not all exports were sent to boycotting countries. But the domestic market was definitely more important than the export market for wine farmers during the 1980s, which the KWV emphasized in the debate over sanctions.

While sanctions did not impact wine farmers to any great extent, fruit farmers were in a more precarious situation. According to the president of the Deciduous Fruit Board, Leo Fine, 75 per cent of the income of the Board came from exports. Therefore, the fruit industry was "particularly vulnerable to sanctions". As a result of this, the Board was searching for other possible export markets overseas. Fine expected that about 80 per cent of the following year's crop would be exported and the rest would be "absorbed by the local market". He expected that the situation would deteriorate in the long-term, "but the industry would remain directed towards

\footnotetext{
${ }^{261}$ Farmers' Weekly, Nov. 7, 1986.

${ }^{262}$ Farmers' Weekly, Sept. 26, 1986.
} 
the export market". The sanctions thus affected fruit farmers severely, but if they suffered, so would the labourers. Fine explained that "many labourers would have to be dismissed if exports decreased". ${ }^{263}$ Since the labourers had very little security outside of the farm, the sanctions would actually be worse for them than for the farmers. The farmers could decrease their production and sell less, which meant lower income, but if they fired some of their labourers or lowered wages they could still make profits. And if they found other markets they could again expand production. They would thus be able to stay on the land as farmers. Labourers did not have the same options. If exports decreased, they risked being unemployed.

The vulnerable position of farm labourers was also used by the farmers in the debate over the effects of sanctions. Farmers' Week$l y$ argued that the farm labourers were at the "sharp end of sanctions", ${ }^{264}$ which was not untrue. But more importantly, the farm labourers themselves did apparently not support sanctions, at least not in their own industry. According to the chief executive of the Deciduous Fruit Board, Louis Kriel, more than 90 per cent of the black labourers in the deciduous fruit industry were "totally opposed to sanctions involving their industry". This could of course mean that they were not opposed to sanctions in general, only when it affected their industry. While it is unclear how Kriel arrived at that figure, it is evident that farmers used labourers to argue against sanctions. The debate about sanctions in, for example, Sweden was clearly not based on opinions of the working class in South Africa, but on the exile ANC members. ${ }^{265}$ By stating that the labourers were not in favour of sanctions, the farmers could bring them in as an ally against foreign enemies. It is also unclear why Kriel only referred to the black labourers and not the coloured ones, who were the majority in the Western Cape. It is likely that coloured labourers in fruit farming were also worried that sanctions potentially could result in unemployment for them. However, since the ANC was mainly based on blacks, the argument that

\footnotetext{
${ }^{263}$ Farmers' Weekly, Oct. 17, 1986.

${ }^{264}$ Farmers' Weekly, Oct. 31, 1986.

${ }^{265}$ See Sjölander, 2014.
} 
more than 90 per cent of black labourers in fruit farming were opposed to sanctions could have been used to exemplify that the ANC policy was not supported by the people they represented in South Africa. That clearly sent a message both to decision makers abroad and to South Africans in the country, that the ANC was not a legitimate organization, since its policies were not established in the opinions of the oppressed people in South Africa.

The black labourers were not opposed to sanctions only because it would affect them, though, according to Kriel. Instead, he stated that they opposed sanctions "because deciduous fruit producers have provided some of the best working and social conditions in the world for their employees". It was through exports to countries such as the U.S. that farmers had been able to "create those conditions". Kriel's statement was clearly an exaggeration in view of the working conditions on fruit farms described by for example Wendy Davies, which included child labour and extremely low wages. ${ }^{266}$ However, although it was absurd to call the working conditions "some of the best in the world", it did not exclude the possibility that conditions had improved during the previous years. The editorial in Farmers' Weekly argued that

[n]o informed person can deny that tremendous progress has been made in improving training as well as working and living conditions of farm labour, and that should the agricultural economy become further depressed, it will be a major setback. $^{267}$

The issue, then, for farmers and their representatives was to emphasize that farmers had improved conditions on farms and that sanctions would deteriorate the situation instead of creating better conditions. Organized agriculture thereby tried to use the sanctions to bring the labourers closer to the farmers instead of creating a divide between them. This must be included in explanations of how the labour relations on farms changed, which du Toit described as a new form of paternalism, where labourers were more interested in the success of the farm than in reducing the exploitation of themselves by farmers. If farm labourers regarded the sanctions as

\footnotetext{
${ }^{266}$ See Davies, 1990.

${ }^{267}$ Farmers' Weekly, Oct. 31, 1986.
} 
a threat to their employment and social security, it is likely that they allied themselves with farmers instead of with those who imposed sanctions. The sanctions probably also gave incentives to farmers to further improve their relationship with labourers as they required their support as well as their labour. In that regard, it is thus possible to argue that the sanctions had a positive effect on labour relations, but at the same time they created a stronger relationship between farmers and labourers, which was based on the paternalist structure already prevalent on the farms. To some extent, sanctions thus brought capital and labour in the Western Cape closer together, since both were threatened by them.

It is difficult to determine how the use of the dop system changed as a result of increasing external and internal pressure in the form of sanctions and trade union activity, but it is apparent that such forces, combined with the desire among farmers to improve production and increase the skills of the labourers in order to be more profitable, resulted in changed labour relations during the 1980s and 1990s. As Marcus has pointed out for the period before the 1980s, the transformation of South African farming in general meant that farmers entrenched their power as labour tenants became wage labourers. In wine farming, a similar process occurred after the 1970s, when farmers transformed production by investing in new technology and in the labour force through training and also improved conditions for the permanent labourers and allowed them to participate in decision making. The transformations in wine farming also stratified the labour force. Those who received training could benefit and be paid higher wages, while others remained "unskilled" and more vulnerable as seasonal labourers. The wine farmers in the Western Cape appear to have been among the first ones who implemented such strategies in South Africa, partly because it was required in order to improve production, and partly because there was pressure from outside to do so. The result was improved conditions for some labourers, at least for the permanent labourers on farms where investments were made, and a closer relationship between farmers and labourers, while conditions did not improve on farms where few investments were made. Labourers on the less progressive farms continued to 
be in a position where they had little opportunity to influence the farmers and improve their own situation at work, for example through obtaining skills and thereby higher wages. 


\section{NEW CONDITIONS FOR CAPITAL ACCUMULATION - WINE FARMING AND LABOUR RELATIONS IN THE POST-APARTHEID ERA}

\section{Deregulation and competition on the international market}

Since the creation of the KWV in 1918, the wine industry had been the most regulated of the agricultural sectors in South Africa. The KWV set prices and bought crops, which ensured income for farmers, and it also had a monopoly on liquor exports in the southern hemisphere. Wine farming was indeed in the hands of the white minority, especially the Afrikaners. The wine farmers in the Western Cape had also been among the strongest supporters of the $\mathrm{Na}$ tional Party, and had benefitted from that support through the KWV's position. But, as we have seen, from the 1970s there was an independent wine farming movement of mainly estate producers, who wanted to free themselves from the KWV and its influence, which they perceived as limiting.

During the 1980s, monopolies and state regulation were increasingly challenged, however, which generated new conditions for farming in relation to international markets. In 1984, the KWV allowed a "limited market in wine quotas" in each of the wine regions, and in 1992 the organization decided to abolish quotas. The co-operatives would instead be in charge of regulating production and were apparently "encouraged to define, limit and even charge for their members' rights to crush grapes". This meant that cooperatives were required to differentiate more between the grapes 
from their members and the prices they paid for them. ${ }^{268}$ The $\mathrm{KWV}$, however, continued to be the dominant actor in the wine industry. It still controlled most of the export and import market. But in 1996, a decision was made to convert the KWV from a cooperative to a private company. ${ }^{269}$

The decision to convert to a company was not unproblematic; the Minister of Agriculture argued that the regulatory function of the KWV was not necessarily best handled by a private company. However, in 1997, it was decided that the KWV was allowed to become a company with the members as shareholders. While the KWV had no regulatory role, it would continue to promote "certification of wine, plant improvement, research and development, establishment of new farmers, upliftment of farm worker communities in the wine industry and the administration of a voluntary surplus removal system". ${ }^{270}$ After negotiations about the conversion were completed, the KWV announced that it would not enter the domestic market, but continue to expand internationally. The KWV was, however, not forced to stay out of the domestic market as it had been in the past. In 2000, the KWV therefore decided to enter the domestic market as well. But it did not have the benefit of being guaranteed deliveries of surplus grapes, which had been the case previously; instead it had to compete with other co-operative cellars for supply of grapes. But as part of the negotiation deal to become a company, the KWV also agreed to contribute funds to the South African Wine Trust, which were supposed to be used for research, promotion and empowerment of disadvantaged farmers. $^{271}$

As the largest actor in the South African wine industry, the KWV thus still had obligations to the industry, not just the shareholders. The chairman, Lourens Jonker, even declared in 1997 that the conversion to a company "will be to the benefit of consumers in the international markets, as well as in the interest of the broader South African wine community and its workers". ${ }^{272}$ Jonker did not

\footnotetext{
${ }^{268}$ Vink et al., 2004, pp. 236-37.

${ }^{269}$ Vink et al., 2004, p. 238.

${ }^{270}$ KWV Annual Report, 1997, p. 6.

${ }^{271}$ Vink et al., 2004, p. 239.

${ }^{272}$ Wynboer, May, 1997.
} 
elaborate on how the conversion to a company would benefit either of those groups, though. The funding of upliftment for disadvantaged groups, which was part of the agreement to convert to a company, could be regarded as a contribution that benefitted labourers, but that sort of funding could have been done even without a conversion, for example as had been done when the KWV funded the Rural Foundation.

Deregulation and the end of sanctions in 1993 opened up new markets for South African wine farmers. They were able to compete on the international market again and exports increased considerably during the mid-1990s; between 1994 and 1997 exports increased by 1,000 per cent. After that exports were reduced to 5 per cent per year, but increased again to 26 per cent in $2002 .{ }^{273}$ But also sales in South Africa were improved with an increase of about 20 per cent between 1993 and $1999 .{ }^{274}$ The deregulation was profitable for some, but less profitable for others, who had been dependent on the support from the KWV. And although deregulation directed farmers away from the quota system, the South African wine industry was still to a great extent aimed at producing low quality wine. ${ }^{275}$

The greatest export market for South African wine was Great Britain. Exports to Britain increased from 1.9 million cases in 1994 to 3.2 million cases in $1997 .{ }^{276}$ South African wine had a good reputation on the British market in the late 1990s. But it appears that reports about poor working conditions on South African wine farms reached Britain, which Wynboer argued could be detrimental to the favourable position. ${ }^{277}$ One solution to that problem was the Ethical Trade Initiative, a British trade organization promoting fair labour relations in all stages of the commodity chain of a product. Wynboer argued that the Ethical Trade Initiative was of value to wine farmers. Already during the first years after apartheid, a number of producers joined the Ethical Trade Initiative and new companies were started, where labourers were given part of the

\footnotetext{
${ }^{273}$ Ewert and du Toit, 2005, p. 321.

${ }^{274}$ Ewert and Hamman, 1999, p. 206.

${ }^{275}$ Vink et al., 2004, p. 239.

${ }^{276}$ Wynboer, March, 1998.

${ }^{277}$ Wynboer, March, 1998.
} 
ownership, for example Thandi wines. There was a great interest among both South African farmers and wine producers, and among foreign capital owners, to invest in ventures, which were based on upliftment of black and coloured labourers. Some of them were rather successful on the international market. In Britain, it was reported, people wanted to support wines that represented a new direction for South Africa after apartheid. ${ }^{278}$ The measures taken to improve the reputation of South African wine in Britain have definitely been successful during the twenty-first century. In 2012, Britain was by far the largest export country for South African wine; about 22 per cent of exports went there. ${ }^{279}$

One of the successful wine farmers in the twenty-first century is Beyers Truter, who owns the farms Beyerskloof and Beyerskloof Vineyards in Stellenbosch. Truter started as winemaker at Kanonkop in 1981. Thereafter he bought his own farm in 1988. The farm had been in the family previously, but had belonged to others for about eighty years. The farm itself is thus old. According to him, the recipe for success has been intimate knowledge about wine, grapes and the people he works with. Truter has focused on a variety of Pinotage grapes, and been able to produce high quality wines. $^{280}$

Wine farming has not alone constituted the income on the farm. Also wine tastings and a restaurant have been important sources of income, according to Truter: "It's a big part of our sales and also generates a lot of publicity for your label". Truter mentions that the wine route started by Frans Malan and others has been important for wine farming. But those who have invested in the industry since the 1990s are mainly those with "big check books". These are bankers and others with much capital resources. "It takes a lot of money to be a wine farmer", he says, "it's a costly business". But he also welcomes these new farmers with big check books: "We need people like that; we need people to put in money to raise levels and to keep fields maintained". ${ }^{281}$ For farmers like

\footnotetext{
${ }^{278}$ Wynboer, March, 1998.

${ }^{279}$ South African Wine Industry Statistics (SAWIS) 2013, p. 27.

${ }^{280}$ Beyers Truter, Beyerskloof, interview, 2013-11-26.

${ }^{281}$ Beyers Truter, Beyerskloof, interview, 2013-11-26.
} 
Truter, who have been successful, the competition from others who invest large sums has been positive, since it gives impetus to the industry as such and benefits also him.

However, while Truter has benefitted from substantial investments into the wine industry, others have not been so fortunate. The number of grape producers has decreased considerably during the twenty-first century. From the 1950s to the 1990s there were about 4,500 wine farmers, but in 2009 there were only 3,440 wine farmers (primary grape producers) in South Africa. ${ }^{282}$ Since the number of wine farmers was steady during the apartheid years, it appears that they relied on the support of the KWV. These farmers were not equipped for farming in the twenty-first century and consequently had to sell their farms to those who were.

While ownership of farms tended to be concentrated in fewer hands, production of wine was characterized by an opposite trend during the early twenty-first century, at least regarding the number of producers. Between 2003 and 2012 the number of cellars that crushed grapes increased from 505 to 582 . The main increase was seen among the private cellars, which increased from 349 in 2002 to 509 in 2012. The co-operative cellars (also called producer cellars) have shown a decreasing trend, from 66 in 2003 to 50 in 2012. ${ }^{283}$ The increase in the number of private cellars demonstrates that investors have focused on that part of production especially. Some of these can of course be owned by the same person or company, which means that we cannot for certain conclude that the ownership has been spread in more hands, but it is still interesting to note that the number of private cellars have risen, while cooperatives have decreased in number. Investments into private cellars have apparently been attractive; as Truter explained, much of it has probably been done by those with big check books. At the same time the co-operatives have been forced to merger or close down, as it seems.

Private cellars are primarily found in Stellenbosch and Paarl. In Stellenbosch, the number increased from 160 in 2003 to 178 in 2012, while the number decreased slightly in Paarl from 132 to

\footnotetext{
${ }^{282}$ SAWIS 2013, p. 6.

${ }^{283}$ Vink et al., 2004, p. 242; SA WIS 2004, 2013.
} 
128 during the same period. But private cellars have also been established in other regions. In Robertson the number increased from 41 to 54 and in Worcester from 34 to 52 between 2003 and $2012 .^{284}$ There has thus been an expansion of wine production to other regions, although Stellenbosch and Paarl have been at the centre of the industry and continue to dominate wine production.

The success of private producers has been related to the export market. In 2012, the exports constituted 417 million litres, or about 54 per cent, and domestic sales 361 million litres. ${ }^{285}$ We have seen that wine farmers and their organizations tried to create a larger domestic market by increasing the wine drinking part of the South African population. This was discussed during the 1950s and 1960s when the KWV wanted wine farmers to be able to sell wine to blacks, for example. But it was also an important topic for the innovators of wine farming in the 1970s, and especially during the 1980s when sanctions closed the door to exports. It is possible that the efforts made to increase the interest in wine were successful to some extent, but after the mid-1990s, wine has been in decline as a beverage in South Africa. Total wine consumption decreased from 373 million litres in 1996 to 361 million litres in 2012 and the per capita consumption of wine has also decreased during those years from 8.10 to 6.18 litres per year. The most important change, at least for farmers and producers of wine, is perhaps that the alcohol market share for wine in South Africa has decreased from 16.1 per cent in 1996 to 13.8 per cent in 2012. ${ }^{286}$ South Africans have thus become less interested in wine during the twenty-first century, which indicates that efforts to enhance the domestic wine market have not been particularly successful.

One important aspect of domestic sales has been the role of the supermarkets. In 1995, liquor legislation changed so that supermarkets were allowed to "stock more wine in more outlets" and thereby could improve their position on the wine market. ${ }^{287} \mathrm{~A}$ representative of one of the large supermarket chains explained that

\footnotetext{
${ }^{284}$ SAWIS 2013, p. 7.

${ }^{285}$ SAWIS 2013, p. 5.

${ }^{286}$ SAWIS 2013, pp. 30-31.

${ }^{287}$ Wynboer, Dec., 1998.
} 
their buying power and lower mark-ups enabled them to offer wines at "competitive prices". In many cases the wine sold in supermarkets was cheaper than the same wine sold at the farm. Graham de Villiers, a farmer in Franschoek and chairman of the South African Wine and Spirits Export Association (SAWSEA), explained that by buying big volumes, the supermarket could negotiate good prices. However, according to de Villiers, the higher prices at cellars was also a result of the costs in relation to sales on farms, which included a tasting room, wine for tasting and a qualified staff. Most farmers were thus in favour of selling the majority of their wine in other places than on the farm. Wine tastings and sales on the farm were instead more a form of marketing. ${ }^{288}$ The supermarkets thus became important actors in the wine industry, mainly because of their ability to offer "competitive prices", which must be understood as low prices.

The rise of the supermarkets and the competitive prices has, in turn, affected both farmers and labourers. Mercia Andrews from the Trust for Community Outreach and Education (TCOE) claims that the "supermarkets squeeze the farmer and the farmer passes that down to the farm worker". ${ }^{289}$ In the end, it is thus the farmers and the labourers who pay the price for low prices on wine. The same logic clearly also applies to the export wine. Supermarkets and retailers in Britain such as Tesco and Sainsbury's constitute the main retailers of wine, and they also buy in bulk and sell at competitive prices. Although farmers want to get a contract with the British supermarkets, it also means that there will be competition between supermarket and farmer for the price, which impacts the farm labourers, since farmers must keep production costs down.

But the supermarkets also inspect conditions for labourers on farms. Incidents on farms can impact the relationship between the two. In 2007, the organization Women on Farms attended the Annual General Meeting of the British supermarket Tesco. At the meeting, representatives of Women on Farms claimed that conditions for farm labourers in the Western Cape were not up to standards, and especially emphasized that women were poorly paid, and

\footnotetext{
${ }^{288}$ Wynboer, Dec., 1998.

${ }^{289}$ Mercia Andrews, TCOE, interview, 2013-12-02.
} 
that the dop system was used. A farm labourer from the Western Cape accompanied Women on Farms to the meeting and testified to the poor conditions. Tesco thereafter conducted its own investigation of conditions on farms in the Western Cape, which concluded that the farm labourer in question had "generalised broadly" and that "producers were paying their workers minimum wages and that their living and social conditions were acceptable according to Tesco's standards". ${ }^{290}$ The supermarkets thus investigate conditions on farms, but at least in this case only after reports of maltreatment and unfair practices had become known and discussed in the media. Further, it is clear that the supermarkets and retailers do not attempt to raise the standard for labourers; instead of making demands on farmers they only ensure that they comply with legislation and pay minimum wages.

There is, of course, no reason for supermarkets and retailers to demand labour reforms that would increase costs for farmers. In fact, their profits are to a great extent based on low costs in the beginning of the commodity chain, at the primary producer level. So, the advantage for supermarkets is not only based on buying in bulk and negotiating good prices, it is equally important for them to find producers that can guarantee low production costs. If farmers cannot keep their production costs down, they will have to charge more for their wine, which will cause supermarkets and retailers to increase prices to consumers. That can obviously be done if consumers are prepared to pay more for the wine, but since "competitive prices" often determine where consumers will shop, it is not a likely scenario. The supermarkets will then find other producers who can guarantee low costs.

However, wine as a commodity is not only consumed because it is cheap, also the quality is of importance to consumers and must be adhered to. The CEO of Wines of South Africa (WOSA), Su Birch, was therefore pleased to report in 2007 that Tesco not only had increased the number of South African wines by 35 per cent to 80 wines, but also that for "the first time, the chain is stocking local wines in the $£ 15$ to $£ 20$ range $[\ldots] " .{ }^{291}$ Brands such as Bey-

\footnotetext{
${ }^{290}$ Farmers' Weekly, Jan. 19, 2007; July 27, 2007.

${ }^{291}$ Farmers' Weekly, Sept. 21, 2007.
} 
erskloof, Nederburg, Spier and Boschendal showed stable sales, but Kumala, the biggest South African export brand, had even "retained its status as one of the top 10 retail brands". South African wines were apparently popular and not only because they were comparatively cheap. During the previous year, there had been a volume increase by 2.1 per cent, but more importantly a value increase by 7.2 per cent. ${ }^{292}$ South African farmers had thus not only benefitted from low production costs, at least some of the producers had also managed to produce better quality wine and increased the value of the commodity. By doing so, the farmers could increase their profit margins, which may have meant less of a "squeeze" on the labourers on those farms.

The ones who sold wines in the higher price ranges were few, though, and for the majority of farmers there was not the same opportunity. Those who produced for co-operatives or private cellars could surely also benefit from improved wine sales, but would have to share profits with many others.

\section{The new labour relations}

The end of apartheid had an impact on labour relations in the country and perhaps specifically in agriculture. Already before the 1994 elections, through the Agricultural Labour Act (No 147 of 1993), labour legislation changed in agriculture so that also farm labourers were included in the Labour Relations Act and the Basic Conditions of Employment Act, which they had not been previously. This was the first time that farm labourers had been protected by labour legislation other than the Masters' and Servant's Act, which was abolished in the 1970s. In 2003, a minimum wage was set for farm labour through sectoral determination of the Basic Conditions of Employment Act. New sectoral determinations were made in 2006, 2009, 2012 and 2013.

Labour relations in wine farming in the post-apartheid era have been characterized by increasing mechanization together with seasonalization and casualization. Ewert and du Toit argue that the policy decisions about transformation of the wine industry, for ex-

${ }^{292}$ Farmers' Weekly, Sept. 21, 2007. 
ample by the KWV towards more equality between blacks, coloureds and whites through Black Economic Empowerment (BEE), have not been very successful. Upliftment of the previously underprivileged groups have not generated improvements for labourers to any great extent either. Instead the farmers have evicted people and have taken less social responsibility for seasonal labourers. ${ }^{293}$

The sectoral determination of conditions and wages has been important for labourers because it has stipulated certain basic conditions. But it has not necessarily implied an improvement of wages. The minimum wage for 2003 was R800 per month or R9,600 per year. ${ }^{294}$ If we compare that wage with the levels of 1975 by a conversion of the value of the Rand, we see that the minimum wage in 2003 was not an improvement in monetary terms. The district with lowest wages in 1975 was Robertson, where wages, converted to the value of 2003, was R9,006. ${ }^{295}$ The minimum wage, meaning the lowest wage paid to labourers, thus appears to have increased very little or not at all between 1975 and 2003. The minimum wage set in 2012 meant an increase for labourers also in real terms. The new minimum wage was set at R18,047 per year, which was twice as much as in 2003. ${ }^{296}$

In order to assess the increase of farm labourers' wages we can compare them with the income for farmers. The total income for grape production in 2002 was R2.075 billion and in 2012 it was R4.131 billion. ${ }^{297}$ The farmers had thus doubled their income in nominal terms. If we consider that the number of farmers was reduced, the profit for the individual farmer was even higher in 2012. At the same time the seasonalization of labour has implied that farmers use less labour throughout the year and therefore logically pay less wages overall. The increase of the minimum wage must thus be related to the length of employment for the individual labourer. Since an increasing number of labourers are seasonally employed, they might earn less although their wages have increased.

\footnotetext{
${ }^{293}$ Ewert and du Toit, 2005, pp. 324-332.

${ }^{294}$ Government Gazette, Dec. 2, 2002, Sectoral determination 2002, p. 5.

${ }^{295}$ Conversion fxtop, http://fxtop.com/en/historical-exchange-rates.php?MA=1, 2014-05-08.

${ }^{296}$ Government Gazette Feb. 24, 2012, Sectoral determination 2012, p. 3.

${ }^{297}$ SAWIS 2013, p. 19.
} 
The new minimum wage after the strikes in 2013 was set at R2,273.52 per month or R27,282 per year (R105 per day). That meant that the minimum wages in real terms for the first time were higher than the wages paid in Stellenbosch in 1975. In that regard the strikes and the negotiations were a success for labourers and their representatives. However, the increase was not as significant as many of the farmers argued. According to Joey Cloete from the trade union BAWUSA, the previous minimum wage of R69 per day did not reflect the actual wage levels. Most of their members, and also many non-unionized labourers, earned more than the minimum wage, probably between R80 and R95. Many even earned R105 or more, according to Cloete. The increase to R105 did thus not cause much harm to farmers, who already paid higher wages than the previous minimum wage. ${ }^{298}$

The farmer on Kanonkop, Johann Krige, was not worried that the new minimum wage would have an impact on his farm since his labourers earned a lot more. ${ }^{299}$ He does not mention how much he pays in wages, but labourers on the farm confirm that they are paid higher wages than most labourers in the region. On Bosman, the average cash wage paid "in season" is R150 per day, thus about 50 per cent higher than the minimum wage. But an overall increase of wages, amounting to 15 or 18 per cent, was required after an evaluation of housing, water, electricity and other benefits had been made. ${ }^{300}$ Although cash wages were high on Bosman, the benefits appear to have been valued too high in relation to cash wages. Also those farmers who pay high wages are therefore not always up to standards, since the total wage is also based on the value of benefits for labourers. These benefits can clearly be valued differently depending on where the farm is located, for example since land and house prices differ and transport costs can vary depending on distances to towns, schools, medical facilities etc.

The seasonal character of labour relations has implied insecure working conditions for labourers, but also that their position has weakened compared to what was the case in the twentieth century.

\footnotetext{
${ }^{298}$ Joey Cloete, BAWUSA, interview, 2013-12-06.

${ }^{299}$ Johann Krige, Kanonkop, interview, 2013-12-11.

${ }^{300}$ Petrus Bosman, Bosman Family Vineyards, interview, 2013-12-10.
} 
It has become easier for farmers to fire labourers and hire them on seasonal contracts. By doing so, the farmers can pay lower wages. Joey Cloete from BAWUSA says that about eighty per cent of the seasonal labourers earn the minimum wage. Some of them have been in farm labour for thirty years, and are skilled, but are only paid the minimum wage. ${ }^{301}$

According to Mercia Andrews, the twenty-first century, and especially the years after 2008, have been characterized by the rise of labour brokers. The labour brokers hire out seasonal and casual labourers to farmers on contracts and are the ones responsible for paying wages. The labour brokers were previously mainly black and coloured, she explains, but recently an increasing number of whites have entered the business. The labour brokers are used for example during harvest time when farmers demand much labour, but also at other times. On Kanonkop, the farmer Johann Krige says that he will not employ any more labourers. If he requires more labour he will use "contractors", since it means that he will not have to worry about housing for labourers or other costs. He just pays the contractor, and then it is the responsibility of the contractor to make sure that the labourer is paid according to legislation. In December 2013, there were about eighty seasonal labourers on Kanonkop, while the permanent labour force was about thirty people. The seasonal labourers were not doing the same work as the permanent labourers, who are mainly found in the production of wine and as tractor drivers. The seasonal labourers work in the field, sometimes under the supervision of a permanent labourer. Lawrence, a farm labourer on Kanonkop, is not worried that the use of seasonal labourers will make the permanent labourers redundant. He says that the permanent labourers talked to the farmer about the contract labourers and said that "OK, bring in the contract workers, but they mustn't do our job". They are thus not against bringing in contract labourers as long as the farmer makes sure that their work does not interfere with the work of permanent labourers. But it is important that the permanent labourers can trust the farmer. Lawrence explains: "If it rains or [is]

\footnotetext{
${ }^{301}$ Joey Cloete, BAWUSA, interview, 2013-12-06.
} 
sunshine or whatever, every day there must be work for us. They can come in [...] but there must be work for us." ${ }^{302}$

While seasonal labour is cheaper for farmers, as they do not have to provide housing etc. and only pay wages during a part of the year, it is often the same labourers who return year after year. Anrí Truter, son of Beyers Truter and manager on Beyerskloof, explains that they usually hire the same people for harvests. The reason is that the labourers want to come back. The wages are comparatively high on the farm, which ensures them of a steady supply of seasonal labour. The Truters usually recruit the labourers from the township Kayamandi in Stellenbosch. They are not only hired during harvest time, though. Between September and December, a team from Kayamandi is hired to conduct "vineyard management", which includes pruning, breaking off shoots etc. They get training for this before they start working. Anrí Truter explains that they often contact those who have been seasonal labourers to come as permanent labourers if a position opens up on the farm. It is easy to see who among the seasonal labourers are good and could have a future as a permanent labourer, he explains. After a trial period of 3 to 6 months they can become permanent labourers on the farm. ${ }^{303}$ Being a seasonal labourer can thus lead to permanent employment, although there are relatively few positions as a permanent labourer.

The opportunity to become a permanent labourer also exists on Bosman. Twice a year they offer some of those who have worked as seasonal labourers contracts of permanent employment. On Bosman they do not use outside seasonal labour, instead they hire family members of those who already live and work on the farm. There are about two hundred labourers and about one thousand people altogether on the adjoining farms owned by Bosman. There is consequently a large supply of seasonal labour, which constitutes a reserve labour force that can be utilised for example during harvests.

The large labour force on Bosman is not seen on most other farms. According to Petrus Bosman, the character of the farm's

\footnotetext{
${ }^{302}$ Lawrence, Kanonkop, interview, 2013-12-11.

${ }^{303}$ Anrí Truter, Beyerskloof, interview, 2013-11-15.
} 
production enables them to have a large labour force. Bosman produces wine, but there is also a vine nursery on the farm, which was the main activity of the farm during the second half of the twentieth century until 2007, when wine production was started again. The vineyards and the wine production require much labour during the summer, for example in pruning and harvesting, while the nursery requires labour during the winter. All the grafting, for example, requires manual labour and is labour intensive. But also the harvest is done manually, without any machinery. ${ }^{304}$ There is thus work all year round for the large labour force. The variation of production on Bosman is not seen everywhere. For those who only have vineyards there is less labour in the winter, although a certain number of labourers is required in for example spraying, weeding and wine production.

The seasonal character of agriculture was exploited by Western Cape farmers in the nineteenth century. Whereas wine farmers required much seasonal labour during harvest time in the summer, other farmers required labour at a later stage during the year. Many labourers therefore alternated their employment between different agricultural sectors, which also resulted in problems. Those farmers who could afford often paid advances to the labourers to be ensured of their labour during harvest time or other parts of the year when labour demand was high. The advances were sometimes enough for labourers to be able to refuse work during parts of the year, which resulted in a lowered supply of labour for those farmers who could not pay enough in advances to secure labour. ${ }^{305}$ In the twentieth and twenty-first century, that does not appear to be a problem. Seasonal labour is abundant due to lowered levels of permanent employment and the overall high employment rate in the country. In addition, migrants from neighbouring countries, who have come to the Western Cape in search of income, have increased the supply of seasonal labour.

Most farmers do not have a large supply of seasonal labour readily available on the farm and they are actively trying to recruit labour, often in quite distant places. Joey Cloete mentions that sea-

\footnotetext{
${ }^{304}$ Petrus Bosman, Bosman Family Vineyards, interview, 2013-12-10.

${ }^{305}$ Scully, 1990, pp. 54-55.
} 
sonal labourers come to the Western Cape from both the Eastern and the Northern Cape. Some travel as far as a thousand kilometres for work, most of them have families to provide for. Farmers still use a form of advance system to attract the labourers, though. Many are apparently housed in hostels at the expense of farmers and when they start working, they are indebted. Cloete says that during the first two or three weeks, the labourers cannot send anything of their earnings back to their families, instead they have to pay off the debt to the farmer. While working, they even "incur more debts because they must live", for example since they buy food from a shop on the farm or have to pay off accommodation. According to Cloete, the situation is actually "breaking up families". It is especially the blacks who suffer from this system. ${ }^{306}$ The families of black migrants are more dependent on the money from migrant labour and they are also the ones who constitute the majority of the labour migrants. Migrant labourers obviously find the insecure conditions on farms in the Western Cape better than what they had in the areas they have come from, indicating that the overall employment rate in South Africa is a main contributing factor behind the willingness to travel long distances for low-paid work. But also the low profit margins for farmers contribute to the problem. The farmers are "desperate for labour and the farm workers are desperate for earnings". ${ }^{307}$ Clearly, the desperation, which Cloete refers to, is an example of how the squeeze on the farmer from supermarkets and retailers is passed on to the labourers. The problem for labourers is that they are too many in relation to the farmers and that they have little influence over working conditions. The supply of labour exceeds the demand for labour, which the farmers benefit from.

\section{Fair wages instead of Fairtrade}

The South African wine industry has become export oriented since the 1990s. Thereby, conditions on wine farms have become subject to debates also in other parts of the world, most notably in Europe. The Ethical Trade Initiative and the Fairtrade label are examples of

\footnotetext{
${ }^{306}$ Joey Cloete, BAWUSA, interview, 2013-12-06.

${ }^{307}$ Joey Cloete, BAWUSA, interview, 2013-12-06.
} 
how farmers have started to use "fair" conditions as a method of marketing their product and a way to improve their reputation and their brand. Danie Niemand from the Department of Agriculture explains that fair trade has had an impact, both on exports and sales on the internal market. Wines with the Fairtrade label sell better and farmers respond to that, he says.

The Fairtrade label is, however, not always used on all bottles even if a farm has been certified according to Fairtrade standards. In 2013, Bosman used the Fairtrade label for some wines, but not for all, since it is expensive to use the label for small volumes, and therefore it was only used for larger volumes. ${ }^{308}$ Still, Fairtrade has had an impact on labour relations since farmers are required to provide a certain living standard for labourers, pay stipulated wages and maintain labour standards in order to be certified.

The impact of demands from consumers and the state has clearly had an impact on conditions on farms, but not all farmers appear to be concerned about the opinions of those outside the farm. Johann Krige on Kanonkop claims that he does not care if the labourers work more than they are allowed to according to legislation. He says that the labourers want to work, and he pays them well. Overtime means higher wages, and it is therefore lucrative for labourers to work also during nights and weekends. If the farmer tells them to work, they work. One specific opportunity to earn much wages is during the fermentation process. On Kanonkop they use so called open fermentation, which means that the crushed grapes are stored in open tanks. According to Krige and Lawrence on Kanonkop, that process generates better wine than closed fermentation. The open fermentation is, however, also labour intensive. It implies that a labourer must stir the wine every three hours during a period of some weeks, which means work during both nights and weekends. The labourers do not usually work throughout the night, though; they work in shifts, Krige explains. However, "sometimes they work 24 hours on, the whole day, but they get very good money". ${ }^{309}$ The fermentation process is obviously an opportunity to earn extra wages, and many of the labourers want

\footnotetext{
${ }^{308}$ Antonia Bosman, Bosman Family Vineyards, interview, 2013-12-10.

${ }^{309}$ Johann Krige, Kanonkop, interview, 2013-12-11.
} 
to volunteer to be a part of the team responsible for stirring the wine in the tanks and earn some additional money.

Another example of overtime work is during harvests. Krige claims that it is the labourers who want to work overtime, not him, but that he will not tell them to stop working if they want to continue. If they want to work, they should able to, is his opinion. Being a farm labourer on Kanonkop, but also elsewhere for that matter, implies being ready to work more or less at all times. But Krige emphasizes that he will pay them accordingly: "They know if I need them, they must work, but then I will pay them properly." 310 The practice on Kanonkop illustrates how a farmer can benefit from having a loyal labour force. Even though Krige can order the labourers to work overtime, and sometimes does, it appears that they themselves also take the initiative to do so. The labourers know that they will earn extra income for overtime work, which clearly is an important reason for their initiatives, but at the same time it improves their relationship with the farmer, since they show that they are willing to work hard.

Since the lives of labourers are much dependent on the goodwill of the farmer, it is beneficial to have a good relationship with him. The relationship between farmer and labourer must of course be upheld also by the farmer in terms of paying wages that are high enough for labourers to consider it worthwhile to work overtime. As long as the wages are high, and labourers are content, outsiders such as the state have little possibility of controlling that labour legislation is followed since no one will complain or report conditions that do not comply with legislation. Krige mentions that during his time as a farmer, the labourers have always received an additional one or two month's wages every year, and sometimes even more. Such bonuses ensure that labourers will not complain and instead remain loyal to the farmer.

Even children of farm labourers work on Kanonkop, according to Krige. He says that they want to work, and therefore he allows them to do so. But he points out that only those who are older than 15 years of age, which is the minimum age for labour, are al-

\footnotetext{
${ }^{310}$ Johann Krige, Kanonkop, interview, 2013-12-11.
} 
lowed to work. The children go to school, but they can work weekends. It is especially during harvest time that the children come to work on the farm, which is the usual time when children work in agriculture. Even though the work can be hard, the young labourers "will not complain, they all want to work". ${ }^{311}$ The money earned by children is an addition to the income for their families, which must be regarded as the main reason why they want to work. The children are not forced to work as part of their families' labour power, which has been a way for farmers to access children's labour power in other parts of South Africa in the past. ${ }^{312}$ The children are instead forced to work because the option of not working, if offered employment, is not viable for farm labour families. They take all the opportunities they can get to find employment and earn additional income.

For the children who work on the farm during harvests, the employment is, however, also an opportunity to create good relations with the farmer for the future. It is very likely that they will continue in their parents' footsteps and become farm labourers. Since the permanent farm labour force is decreasing, there are fewer positions to compete for, which means that proving oneself willing to work means an advantage for future employment and perhaps for advancement on the farm. Krige mentions that one labourer on the farm is attending Elsenburg agricultural college and will soon get his degree. Krige has paid for his education and he has worked on the farm during the entire time that he has been at the college. ${ }^{313}$ By being loyal to the farm and working hard, the labourer at the college has thus received an education, which probably entitles him to a managerial position at some level. It is also very likely that the labourer will stay at Kanonkop instead of finding employment elsewhere, since he owes his good fortune to Krige. The loyalty is enhanced by the opportunity to advance in positions on the farm. The Bosman family also utilize such ties of loyalty. They try to fill vacant positions with people from the farm. It is "more fair", according to Petrus Bosman, to allow a labourer who has worked for

\footnotetext{
${ }^{311}$ Johann Krige, Kanonkop, interview, 2013-12-11.

${ }^{312}$ See Lilja, 2018.

${ }^{313}$ Johann Krige, Kanonkop, interview, 2013-12-11.
} 
a long time on the farm to advance in positions than to bring in someone from outside the farm. ${ }^{314}$ When children of farm labourers see that they have the possibility of advancing to higher positions and earn more money than their parents, they probably become more inclined to continue as farm labourers. By offering employment to the children of present farm labourers, and in some cases even offering them education, which enables them to advance in positions, the farmer can easily reproduce the labour force on the farm without the dop system.

\section{The disappearance of the dop system}

The most notable difference in labour relations on wine farms in the twenty-first century compared to the twentieth century is probably the absence of the dop system. In 1997, the KWV reported that "considerable progress had been made in eliminating" the dop system and that "it may be said with certainty that the tot system will only remain in existence in isolated cases". ${ }^{315}$ That view is still dominant. Representatives of all actors in wine farming, such as farmers, labourers, NGOs and the state, claim that the dop system is not used anymore. Danie Niemand from the Department of Agriculture emphasizes that the dop system is illegal, and has been so since the 1960s, and that those who use it should be punished. If it occurs, it is in isolated cases in remote areas, says Leana Olivier from the Foundation for Alcohol Related Research (FARR). Mercia Andrews also mentions that it is possible that it is used, but only in remote areas. The chairman of Dopstop, Charles Erasmus, reported that it still occurred in 2003, but only in "isolated cases" in "outlying rural areas". ${ }^{316}$

The fact that the dop system has occurred in "isolated cases" in "remote" or "rural" areas for more than a decade is noteworthy, since it describes a situation where no one really knows its extent, only that it exists, but that it is of little importance. Joey Cloete from BAWUSA has a slightly different approach and says that "we think it is not used anymore, at least not in the way it used to be".

\footnotetext{
${ }^{314}$ Petrus Bosman, Bosman Family Vineyards, interview, 2013-12-10.

${ }^{315}$ KWV, Annual Report, 1997, p. 10.

${ }^{316}$ Wineland, April, 2003.
} 
This, then, implies that the definition of the dop system has an impact on the prevalence, but also that the system itself might have changed during the twenty-first century. For this study, it is, however, important to emphasize that the dop system, wherein wine was given as part of the wage, is not important in wine farming any longer. According to Cloete, there has been "serious progress" in that regard and he also thinks most farmers want to change the old practices, which included the dop system. ${ }^{317}$ According to Cloete, the farmers thus see the benefits of improving labour relations.

Although the dop system was reduced already before the 1980s, it continued in many areas and was still used in the 1990s. The use of the dop system was thus initially decreased by farmers themselves, thereafter through the recommendations by the Rural Foundation. For those who still used it during the 1990s there was, however, increasing pressure from above to abolish it. In 1994, the ANC denounced the use of the dop system in Parliament, and Nelson Mandela also denounced it. ${ }^{318}$ This was perhaps not surprising, but not necessarily something that farmers would adhere to. But there was also pressure from within the wine farming community. In 1997, the chairman of the KWV, Lourens Jonker, expressed the most explicit criticism towards the dop system up to that point by the KWV. Jonker stated that the "KVW considers the tot system an unacceptable, obsolete and illegal practice". However, it appears that he knew that it still continued on wine farms as he also claimed that

[i]t is for me personally and in my capacity as chairman of KWV extremely frustrating and disappointing that the tot system has on so many occasions been discussed and warned against, and that certain fellow farmers still support this practice. $^{319}$

It is not certain which occasions Jonker referred to. Most likely he must have referred to the work done by the Rural Foundation; the dop system had definitely not been discussed extensively by the KWV previously.

\footnotetext{
${ }^{317}$ Joey Cloete, BAWUSA, interview, 2013-12-06.

${ }^{318}$ Debates of the National Assembly, vol. 2 (Hansard), J. D. Arendse, 2613-2614.

${ }^{319}$ Wynboer, May, 1997.
} 
Jonker's statement, which thus also was the official opinion of the KWV, sent clear signals to farmers that the practices of the past were not acceptable in the new South Africa. The KWV had opposed the dop system since the early 1990s, and their opinion was thus not changed after 1994, but it is obvious that they realized that old practices such as the dop system was threatening to all farmers, since it gave wine farming a bad reputation, both abroad and in South Africa. Jonker explained that the wine industry suffered both financially, because of negative publicity, and "in terms of the enormous negative socio-economic consequences of the system. We cannot afford a minority of farmers to cause so much damage." Therefore, clear signals to the farmers were more important than before. It appears that exports were threatened if the dop system did not disappear, and the KWV would make efforts to only deal with farmers who followed the regulations and laws and "consider buying wine only from such producers and cellars who can give us absolute assurance that employees are not supplied with any products of the producer arising from the tot system [...]". ${ }^{320}$ The efforts from the KWV, and other co-operatives, to only buy grapes from those farmers who do not use the dop system appears to have been important for the improvement of practices on farms. Joey Cloete thinks that an important explanation for the reduced use of the dop system is that many co-operatives announce that they will not buy grapes from farmers who do not comply with legislation. ${ }^{321}$ In 1997, the KWV reported that there had been much progress in eliminating the dop system "thanks to wholehearted co-operation. Several co-operatives took action to eliminate these practices [...]." 322

However, in 1997, Jonker also celebrated the South African wine farmers for what they had done to prevent the dop system: "[T]he industry deserves recognition for the fact that from a 54\% occurrence in 1987, the practice was reduced to $14 \%$ in 1989 and at the moment it is less than $1 \%$." 323 This was proved by a study

${ }^{320}$ Wynboer, May, 1997.

${ }^{321}$ Joey Cloete, BAWUSA, interview, 2013-12-06.

${ }^{322}$ KWV Annual Report, 1997, p. 10.

${ }^{323}$ Wynboer, May, 1997. 
undertaken by the Rural Foundation. It is somewhat peculiar that Jonker's estimate of the occurrence of the dop system had changed since the early 1990s, when he claimed that it was "found" on 1 per cent of the farms, according to a study also conducted by the Rural Foundation, and then in 1997 claimed that it was found on more than half the farms in 1987 and 14 per cent of farms in 1989. The reduction between 1987 and 1989 is clearly remarkable, which gives cause to some doubt regarding these figures. It is likely that Jonker wanted to give the impression that quick changes had been made by farmers during the previous ten years, and that the public, and international wine buyers and consumers, consequently should give them credit for that.

But Jonker even went further in his praising of the South African wine farmers' efforts to improve conditions on farms: "Compared with other wine countries the incidence of this undesirable practice is probably lower than elsewhere." ${ }^{324}$ Jonker did not mention which countries should be used for comparison, but international comparisons were not new. In the 1950s, the KWV also argued that practices similar to the dop system were used in most other wine producing countries. ${ }^{325}$ Related arguments had also been used in the 1980s, when the KWV argued that the labour relations in wine farming had always been excellent. The organization thus had a history of praising its farmers, which was expected, since it represented them. But in the late 1990s it was probably even necessary to do it in order to be able to criticize those who still used the dop system. Since the dop system was regarded as obsolete, the farmers who still used it must therefore also have been regarded as unfit to be wine farmers in the new era. Criticizing the dop system was therefore not only a way to press farmers to comply with the law, it was also a way to celebrate that many wine farmers had managed to transform their production and labour practices in a manner which enabled them to be profitable in the twenty-first century. As Nosey Pieterse remarked in 2008, the dop system had almost been eradicated because farmers understood that anyone who used it would "be an embarrassment to your peers, who will isolate you

\footnotetext{
${ }^{324}$ Wynboer, May, 1997.

${ }^{325}$ Select Committee on the Subject of the Liquor Bill, 1952.
} 
because you bring shame upon the industry". They could simply not continue to use it and still be regarded as respectable in the eyes of fellow farmers, especially among the more successful ones. Pieterse argued that the peer pressure therefore was "a more powerful tool than anything else" in the struggle against the dop system. 326

Although Jonker and the KWV clearly disapproved of the dop system publicly, they were not progressive in their criticism, rather the opposite. Jonker defined the dop system narrowly and explained that it should be understood as "the giving of wine during the work day as partial remuneration" and that it had "been illegal since 1963 ". ${ }^{327}$ The practice of giving wine as wages was, however, not a real issue for farmers in the 1990s. As Schärf and Steyn note, the tots of wine were given in addition to the wages in the 1980s and probably before that as well. ${ }^{328}$ Therefore, it was easy for Jonker to state that the KWV supported prosecutions of farmers who paid wine as wages. ${ }^{329}$

So, the problem during the 1990s was not that farmers paid part of the wage in wine; that had stopped long before. What instead constituted a problem was that farmers provided wine for free, in quantities that they themselves decided, since there was no legal regulation. Jonker mentioned nothing of this practice, however, which is not surprising, since many farmers still relied on it as a means of attracting and retaining labourers. This practice, of giving wine for free, was not uncommon also on the larger farms.

\section{The "soft tot" and responsible labourers}

The practice of giving wine for free as a gift appears to have replaced the dop system to some extent. ${ }^{330}$ According to Wineland, giving wine as a "fringe benefit" in addition to wages has been called a "soft version of the tot system". Wineland suggests that this soft version was common throughout the wine regions and was practiced at farms and cellars. The soft version referred to a

\footnotetext{
${ }^{326}$ Farmers' Weekly, Jan.25, 2008.

${ }^{327}$ Wynboer, May, 1997.

${ }^{328}$ Schärf, 1984; Steyn, 1984.

${ }^{329}$ Wynboer, May, 1997.

${ }^{330}$ Levine, 2013, p. 26.
} 
practice, where the labourer's position decided the amount of alcohol given and "the benefit can only be used to purchase wine at a specific cellar". This was often used in a manipulative way. If labourers did not produce their quota, they lost the benefit. ${ }^{331}$

On Kanonkop, the labourers were given wine for free until the late 1990s. When the father of the current owner was in charge, he gave much to the labourers, according to one of them. They were given wine several times during the day: "It was litres". 332 Johann Krige mentions that in the 1990s they gave the labourers perhaps a bottle "every Friday or once a month", he cannot remember exactly, he says. ${ }^{333}$ However, the practice of giving wine for free ended in the late 1990s on Kanonkop.

Jannie Bosman explains that they used to give wine to the labourers on his farm in the days of the dop system, but it was not as part of the wage and not during the working day. Instead, they gave it to the labourers at the end of the working day. According to Bosman, this practice was, however, far from destructive to the labourers. He explains how both the labourers and the farmer used to gather at the end of the day "under the tree". Bosman remembers those times with affection. There they would talk about the day, what had happened, who had done what, usually in a friendly manner and joking about each other, for example "this one said this, this one did that". It was also a time for arranging and deciding the tasks for the following day. ${ }^{334}$ These times at the end of the day thus offered some moments of relaxation and social interaction between labourers and the farmer, at least according to the farmer Bosman. In one way it was an opportunity for the farmer to tie the labourers closer to him, since he could be seen as one of them. But it was certainly also an opportunity to improve social relations on the farm and to instil a sense of pride in the labourers, as they joined over a glass of what they all had produced together.

Contrary to what Scully argues for the nineteenth century, when the drinking created a social space for labourers, which farmers did

\footnotetext{
${ }^{331}$ Wineland, April, 2003.

${ }^{332}$ Lawrence, Kanonkop, interview, 2013-11-27.

${ }^{333}$ Johann Krige, Kanonkop, interview, 2013-12-11.

${ }^{334}$ Jannie Bosman, Bosman Family Vineyards, interview, 2013-12-10.
} 
not have access to, ${ }^{335}$ the practice on Bosman created a mutual space, which, at least according to Bosman, was shared by farmer and labourers. It is certainly possible that labourers did not regard it as "sharing", but rather as intrusion by the farmer. Still, by allowing the labourers to join, the farmer had entered that social space, and at least during work days increased his control over it. The labourers could of course still drink on their own time, but their drinking during work days was not an arena they themselves controlled. Drinking had also previously, under the dop system, been an important part of the paternalist relations, since labourers were dependent on the farmer for alcohol. But when they drank wine together, drinking in itself had become entwined in the paternalist relations and become an arena where the farmer exercised control. Paternalism was, so to say, internalized through the drinking of wine and the social situation, which surrounded it.

Bosman notes that the practice of giving wine for free was not unhealthy for the labourers. It was their right to take part in the produce of the farm. But the practice still ended, though. Giving something for free was not right, according to Jannie Bosman. Lawrence on Kanonkop similarly states that the current owner does not give things for free. Instead he gives cash, which the labourers can use to buy the things that they want. Lawrence thinks that the transformation from giving wine to paying cash is positive and a form of learning process. ${ }^{336}$ To stop giving wine was in that regard a way for farmers to teach labourers that they cannot rely on the farmers to give them things. The educational aspect clearly corresponds to the paternalist practices on farms, which has been particularly evident regarding farm labourers' drinking habits. Farmers in the 1950s argued that they tried to teach labourers to drink responsibly by using the dop system. ${ }^{337}$ In the 1990s, farmers such as Bosman instead argued that not giving wine was intended to educate the labourers that they should not receive things for free. The issue was thus no longer to civilize through drinking practices, but to civilize by instilling in them a capitalist order,

\footnotetext{
${ }^{335}$ See Scully, 1992, p. 59.

${ }^{336}$ Lawrence, Kanonkop, interview, 2013-11-27.

${ }^{337}$ See Select Committee on the Subject of the Liquor Bill, 1952, p. 338.
} 
which was more exclusively based on the cash wage exchange between employer and employee than on the paternalist relationship based on giving things "for free" in return for labour and loyalty. But Bosman maintains that the practice of giving wine for free was not unhealthy for the labourers. Instead, he argues that it was their right to take part in the produce of the farm. The only problem was that they received it for free.

The view that labourers should be allowed to take part of the farm's produce is shared by other farmers. Johann Krige on Kanonkop says that he cannot say no when the labourers want to have the wine they themselves have produced. But he says that not all labourers get wine. Instead of keeping labourers docile, it is used to differentiate, motivate and reward labourers. Krige explains that he gives wine to some of the labourers. Those who get wine are mainly those who serve on the committees on the farm, because they have more responsibilities than those who do no serve and they do not get paid for the committee work. He also gives wine to those he thinks have good future prospects on the farm. These labourers get a ration of wine each year, which Krige estimates to be worth about R2,000 to R3,000. He does not state the amount given, but we can estimate from the price list of Kanonkop wines in 2014, where prices for $750 \mathrm{ml}$ bottles sold at the farm were R45, R75, R85, R260, R280, R400 and R1,250. ${ }^{338}$ These are the prices for visitors to Kanonkop, who buy wine directly from the farm. This does not mean that the same prices apply to the labourers, but it indicates the value of the wine produced on the farm and the value it would have if being sold instead of being given to labourers. It is likely that the labourers are given the cheaper wines in the price range R45 to R85. If they get the one for R45 they would get between 44 and 67 bottles per year or more or less on a weekly basis. If they get the one for R85 it would mean between 24 and 35 bottles per year, thus at least every other week.

Krige mentions that the wine given to the labourers should be used when they have formal parties, if they invite friends, or for school or church functions. He says that they "must not come and

\footnotetext{
${ }^{338}$ Kanonkop, wine price list 2014, http://kanonkop.co.za/wp-

content/uploads/2013/09/Kanonkop_Pricelist_April_2014.pdf, 2014-04-28.
} 
ask for wine for such occasions, they must use their own wine". In that sense he appears to give labourers freedom to do what they want with the wine. However, he also emphasizes that he only gives wine to the responsible people, those he knows can handle it. There are some "that I would never give", he says. "If I give them a bottle they go home and drink it right away". 339 The ones who cannot handle alcohol can of course purchase it at other places, but they will not be sponsored by the farmer, according to Krige. The giving of wine has thus clearly become a way to differentiate the labourers. On the one hand, there are those who are responsible, who work extra for the committees, who will be useful labourers in the future and who show that they can handle alcohol. On the other hand, there are those who are less responsible and without much prospects. But the differentiation also means that alcohol has become a reward for those who are responsible and work well. It thus motivates the labourers to behave well, work well and take responsibility. Falletisch argues that one important reason why farm labourers drink is that they have been absolved of responsibility. ${ }^{340}$ But, as seen on Kanonkop, farmers want labourers who take responsibility, which was demanded already in the 1980s through the new management methods. It is possible that Krige exaggerates when he notes that only the responsible labourers get wine, but it shows that farmers at least desire responsibility, since that reflects well on them. To argue that labourers are absolved of responsibility is thus to simplify, at least when it comes to alcohol. Surely, the labourers themselves could use that as an argument for their drinking, but on farms such as Kanonkop there are expectations from the farmer that they should be responsible in their drinking and they are also rewarded for it.

The practices on Kanonkop can definitely be regarded as being in line with the new management style, which became popular in the 1980s and emphasized that farmers should reward those who take responsibility. During that time, there was no discussion about giving alcohol to the ones who were responsible, but it is clear that such practices could be used as rewards. The practices on

\footnotetext{
${ }^{339}$ Johann Krige,Kanonkop, interview, 2013-12-11.

${ }^{340}$ Falletisch, 2008, p. 191.
} 
Kanonkop, and the attitude of Krige, also resemble the notions expressed, for example, in the 1950s that coloured and black labourers should be taught to consume alcohol in a civilized manner. The civilized manner of course involves responsibility and good behaviour. The result of the practice on Kanonkop is thus that if labourers prove themselves to be responsible, and work well, or in other words, become "civilized", they will be rewarded with wine by the farmer.

In addition to the wine given to labourers who are responsible, they can also buy wine on the farm. For this they pay lower prices than the tourists, who come to the farm to buy, at least on Beyerskloof. Anrí Truter explains that they subsidize wine prices for labourers, which they call "staff prices" or "student prices", which is a 10 per cent discount. According to Truter, they want people to buy the wine of the farm, and that it is the labourers' right to buy. They have produced it themselves and should thus be allowed to purchase and consume it. Also Truter states that they discriminate between the labourers when selling. It is only the "responsible" labourers who are allowed to buy wine from the farm. Those who are not responsible are not allowed to buy at all. ${ }^{341}$ On Beyerskloof there is consequently the same distinction as on Kanonkop made between responsible and irresponsible labourers; those who can handle alcohol and those who cannot handle it.

Further, on Beyerskloof the wine to labourers is usually sold on Fridays or at special occasions or events like holidays and is not sold at all on Mondays. ${ }^{342}$ The labourers are thus not free to buy the wine when they want, and not all labourers are allowed to buy. Such a practice suggests that the Truters are concerned that the labourers will not handle the wine responsibly; instead it indicates that the labourers will drink the wine immediately after they have bought it. And since they do not sell on Mondays there is definitely a fear that the Monday morning absenteeism could be a problem and that it would spread into the rest of the week.

Problems with Monday morning absenteeism have characterized wine farming since at least the nineteenth century. In the 1950s,

\footnotetext{
${ }^{341}$ Anrí Truter, Beyerskloof, interview, 2013-11-15.

${ }^{342}$ Anrí Truter, Beyerskloof, interview, 2013-11-15.
} 
farmers also complained about labourers missing work and it has been a problem for farmers until the twenty-first century. However, in 2013, Petrus Bosman noted that there had been improvements during the previous ten years. In 2013, there were hardly any labourers who were absent on Mondays due to drunkenness or hangovers. According to him, "the new generation" of farm labourers are much more "motivated" and come to work on time. ${ }^{343}$ The wages paid on the farm, which are 50 per cent higher than the minimum wage, can of course explain the improved motivation to a great extent, which also impacts drinking.

The disappearance of the dop system occurred during the late 1990 s and the first years of the twenty-first century. But this conclusion depends on the definition used. If it is defined as giving of wine as part of the wage, then the dop system disappeared before the 1990s. If it is defined as giving of wine for free, which has never been illegal but still criticized, it continued into the twenty-first century. In some cases, like on Kanonkop, wine is being given as a reward to those labourers who take responsibility and work on the committees. These appear to get fairly large quantities of wine, perhaps a bottle every week or at least every other week. But it is clear that farmers do not promote drunkenness among labourers and therefore do not give wine or sell to all of them, only those who are responsible and who work well. Wine is therefore not something that labourers are entitled to, it is something they can earn to be entitled to, which is an important difference compared to the mid-twentieth century when farmers argued that they could not withhold tots of wine since some labourers would refuse to work without them.

This shift partly indicates that farmers' attitudes have changed, probably as a result of recommendations from the KWV and stronger criticism from the government. But it also indicates that the position of labourers has changed. In the 1950s, the labourers could move to another farm if they did not get what they wanted. Farmers were not prepared to pay higher cash wages to retain the labourers, which is why they complied to give wine even though

${ }^{343}$ Petrus Bosman, Bosman Family Vineyards, interview, 2013-12-10. 
some of them expressed that they did not want to. In the twentyfirst century, the position of labourers is weaker in the sense that their labour is not demanded to the same extent as previously. It is thus easier for farmers, at least for the wealthy ones, to refuse to give wine to labourers they do not trust. Since farmers are more interested in seasonal labour, and the unemployment rate is high, it is not necessarily a problem for farmers if labourers leave the farm. If they require labour, they can easily hire another labourer, either as a permanent labourer or as a seasonal labourer. The labourers on the other hand, cannot afford to lose their permanent position on a farm unless they have found employment elsewhere, which is difficult. For the farmers, the role of alcohol has therefore changed. They no longer use it to create a docile labour force, although that is still a result of the excessive drinking. Instead they use it to motivate, differentiate and reward some labourers. Reversely then, withholding wine becomes a way to punish or discipline those labourers who do not follow the rules on the farm. These labourers get their alcohol from other sources than the farmer and are in that regard less favoured, and hold a lower position in the hierarchy on the farm.

The new position of labourers, as recipients of rewards as opposed to recipients of benefits, suggests that they constitute a new generation of labourers. This does not mean that all labourers on wine farms belong to the new generation, far from it. The new generation of farm labourers appears to be most frequently found on the large estates, where there is a greater demand for skilled labour. On smaller farms it is less likely that they appear. Still, it is valid to talk of a new generation of farm labourers, which, in accordance with Mannheim's definition, has been formed by social processes. ${ }^{344}$ This generation is not so much determined or defined by their age, although that has an impact, as by the place of employment. The socioeconomic context, that is, where the labourers live and work, thereby contributes to the creation of this generation. The labourers in this new generation are different from the ones Schärf described as unskilled or even deskilled through the use

\footnotetext{
${ }^{344}$ Mannheim, 1952.
} 
of the dop system. They are skilled and do not demand wine as part of wages in order to come to work. However, labourers from the old generation are also found on some estates and are most likely the ones described as irresponsible with alcohol and without much prospects on the farm. These labourers resemble the ones described by Schärf.

It must be pointed out that also members of the new generation of farm labourers can be among those who are dependent on alcohol; there is no contradiction in being skilled, responsible, working well, and being dependent on alcohol. It is the forms under which they acquire alcohol and drink it, which is of importance for how the role of alcohol has changed. Surely, wine as a reward can cause alcoholism, but farmers are not dependent on an inebriated labour force. Insecure employment and seasonalization of labour are far more efficient means of control of labourers than alcohol ever was. In the next chapter, the new forms of paternalism, wherein issues of housing and loyalty between labourers and farmers have been important, will be given more attention. 


\section{INSIDE THE FARM GATES AND OUTSIDE - HOUSING, LOYALTY AND SECURITY FOR FARM LABOURERS}

Housing for farm labourers - investment, control and costs The paternalist relationship between farmers and labourers has, to a great degree, been based on the fact that labourers both live and work on the farm. Du Toit has described the farm as a world in itself, with its own rules and separate from the outside world. ${ }^{345}$ Being inside the farm gates, has, literally, implied being in the world where farmers decide. Thereby, housing has been an important part of the paternalist relations on farms, since farmers have been able to control most aspects of labourers' lives and thereby also been able to reproduce the labour force.

The layout of the farm has also reinforced the farmers' control of the labour force. The farmer's house has usually been placed at the centre of the farm, in a dominant position. Labourers' houses have been more hidden, out of sight from the farmer's house, but still close enough for labourers "to be conscious of the farmer's presence", as Scully argues. ${ }^{346}$ This means that they have always known who is in control. To accommodate the labourers on the farm has thus served a disciplinary purpose for farmers, but also an economic one, since they have been able to pay lower cash wages when labourers have not been required to pay rent for accommo-

\footnotetext{
${ }^{345}$ See du Toit, 1993.

${ }^{346}$ Scully, 1992, p. 60.
} 
dation. The economic and disciplinary role of accommodating labourers on the farm has thus been important historically. But during the twenty-first century, this arrangement has started to change. Farmers have fired many of their permanent labourers and instead hired them on seasonal contracts. This transformation of labour relations has also resulted in evictions from farms; farmers do not see it as their responsibility to accommodate labourers who are not full-time employees. It is mainly the permanent labourers who stay on the farm, and the share of permanent labourers is decreasing.

We have seen that housing became an issue for farmers in the Western Cape during the 1980s and that it was a means of improving the living standard on farms. This process continued in the 1990s, when there was greater pressure from the government to improve conditions on farms. According to Farmers' Weekly, one of the "main obstacles" for farmers to provide accommodation to labourers was the high prices on material and labour, which was required for "permanent dwellings of quality". ${ }^{347}$ Farmers were thus reluctant to provide quality housing because it was expensive. This created a demand for inexpensive houses and a company in Cape Town even specialized in producing pre-fabricated small houses, which were regarded as suitable for farm labourers and their families and which were "affordable" to the farmer. The houses were sold both as a "complete kit" or were erected by the company, for a cost of R600 to R700 per square metre. ${ }^{348}$ If the size was 30 square metres, which was the minimum size for which farmers could make deductions for housing from farm labourers' wages in $2002,{ }^{349}$ the cost would be about R20,000 per house. The price was about 25 per cent lower than for similar conventional houses, but if farmers bought the houses "in kit form" there was a "far greater saving". ${ }^{350}$ Farmers could thus let labourers erect their own houses or hire day labourers to do it.

\footnotetext{
${ }^{347}$ Farmers' Weekly, May 5, 1995.

${ }^{348}$ Farmers' Weekly, May 5, 1995.

${ }^{349}$ See Government Gazette, Dec. 2, 2002, Sectoral determination.

${ }^{350}$ Farmers' Weekly, May 5, 1995.
} 
On Kanonkop, the first "proper" houses were built in 1973. These houses still constitute the largest share of accommodation for labourers on the farm. In the late 1990s, four additional onebedroom flats were built, which were "more for the single people". ${ }^{351}$ It is possible that those small houses were similar to the pre-fabricated dwellings described by Farmers' Weekly. Apparently, there was a demand on Kanonkop for more accommodation at that time for labourers who did not have their families around. It is likely that they were used for labour migrants, who had their families in other parts of the country, since labour migration by blacks to the Western Cape increased after 1994.

In 2013, the houses on Kanonkop were rent free. Electricity was also free until 2008. Krige mentions that after 2008 it has become too expensive for him to provide electricity for free. Still, it is subsidized by about 30 or 40 per cent. Kanonkop is thereby clearly an example of the paternalist farms, which characterize the wine regions. The housing for labourers is only one aspect of paternalism, but perhaps the most crucial one, since the access to a house on the farm gives security to the labourers and keeps them dependent on the farmer for many basic means of survival. Not all the labourers live on the farm, however. Some stay outside, in Klapmuts, which is about nine kilometres from the farm. These get free transport to the farm, which is the common practice in the area. On Beyerskloof, the farmer also provides free transport for those labourers who live outside the farm. Most of them live close by in Stellenbosch, but also in Paarl, which is about ten kilometres away. Anrí Truter explains that also labourers who live further away from the farm get free transport. He argues that it would be unfair unless also those who live far away would get transport. ${ }^{352}$ The sense of treating labourers with fairness obviously appears to be fundamental to farmers, and, as du Toit has described, is an important part of the mutual understanding between farmer and labourer. ${ }^{353}$ The fairness is of course expected to be returned in the form of loyalty

\footnotetext{
${ }^{351}$ Johann Krige, Kanonkop, interview, 2013-12-11.

${ }_{352}$ Anrí Truter, Beyerskloof, interview, 2013-11-15.

${ }^{353}$ Du Toit, 1993, p. 321.
} 
from the labourers, who most likely feel less inclined to complain about other conditions when they get free transport.

The practice of housing labourers on the farms is, however, not something that all farmers support. Johann Krige explains that on Kanonkop they have "investigated the possibility" of moving the labourers off the farm to Klapmuts. In 2013, he had already bought land in Klapmuts for the purpose of building houses for labourers. ${ }^{354}$ Krige says he wants to move the labourers off the farm because having them on the farm is a "massive social responsibility". Providing and maintaining the houses is costly, but there are other expenses and responsibilities as well, such as medical attention, taking children to school and transporting labourers to town, which he does not want. These responsibilities and costs have been something that farmers have accepted because they also get something back in the way of a loyal labour force. Krige says that building houses of good quality and maintaining them has been done to get "a loyal workforce", and that it is "the right thing to do", but also that it is a "financial drain". ${ }^{355}$ So, he does not seem to regard the loyal workforce in terms of profitability. But despite loyalty, Krige thinks that the responsibility has become too much and he does not regard it as worthwhile any longer. Instead, his view is that social responsibility is weighing down on him as a farmer and notes that "the burden becomes just bigger and bigger and bigger." 356

It is telling that Krige regards the labourers as a form of farm property that can be moved to where it is best placed for the farmer. But the labourers see it differently. For them, moving off the farm is a step down in quality. Lawrence, who serves on one of the committees on the farm, explains that "Klapmuts is not a place for us". ${ }^{357}$ So, the labourers do not regard living on the farm as negative. Even though they are always conscious of the farmer's presence, they also get benefits such as a safe area to live in, free

\footnotetext{
${ }^{354}$ Johann Krige, Kanonkop, interview, 2013-12-11.

${ }^{355}$ Johann Krige, Kanonkop, interview, 2013-12-11.

${ }^{356}$ Johann Krige, Kanonkop, interview, 2013-12-11.

${ }^{357}$ Lawrence, Kanonkop, interview, 2013-12-11.
} 
water, recreational activities etc. Above all, the labourers feel safe on the farm.

Moving the labourers off the farm to another area where they can all live is seemingly a step away from the paternalist practices to more impersonal capitalist labour relations based on cash wages on farms. There is thus, at least at Kanonkop, a desire from farmers to move away from the paternalist past, and also from the neopaternalist practices, and into a future where relations between farmers and labourers are based mainly on their economic roles as employer and employees on a capitalist labour market.

\section{Independence and dependence}

When farm labourers have been accommodated on the farms, they have been at the mercy of farmers' goodwill. But legislation in the late twentieth century reinforced the farm labourers' rights to the house they reside in. According to the Extension of Security of Tenure Act of 1997, farm labourers cannot be evicted from a house they occupy if they do not supply labour to the farmer. Only in cases where the tenant has committed crimes or poses a danger to their neighbours is it possible to evict him or her. ${ }^{358}$ This will include getting a court order, which means legal costs, and is time consuming. According to Lawrence on Kanonkop it costs perhaps R200,000 to evict a person from a farm and can take as much as four years. ${ }^{359}$

If a labourer who resides on the farm is fired, he or she has to leave the house within a period of six months. However, those who are too old to work, or injured or sick and therefore cannot supply labour, cannot be legally evicted. ${ }^{360}$ Retired farm labourers, children and other dependants, who are not productive on the farm, are thus the ones farmers regard as problems. Providing and maintaining houses, water, sanitation and electricity to these people is therefore a financial loss to farmers, since they do not get labour in return from them. Previously, such farm dwellers - or squatters, which is the term used by many farmers - were not a big problem,

\footnotetext{
${ }^{358}$ Government Gazette, Nov. 28, 1997. Extension of Security of Tenure Act, 1997.

${ }^{359}$ Lawrence, Kanonkop, interview, 2013-11-27.

${ }^{360}$ Government Gazette, Nov. 28, 1997. Extension of Security of Tenure Act, 1997.
} 
since farmers were not required to provide housing of a certain quality. But now farmers have to provide a minimum level of living standard, which costs money.

However, legislation is often not followed by farmers. Human Rights Watch reported in 2011 about cases where farm labourers and farm dwellers lived in houses that were not up to standard, without water and electricity, and in one case actually in a former pigsty. It was apparently also quite common that farmers tried to intimidate those people that they wanted to move from the farm, which is clearly illegal in terms of the Extension of Security of Tenure Act of 1997, for example through sending dogs to their houses at night and through other illegal means. ${ }^{361}$

Even though evictions are illegal and costly for farmers, they are frequent in the Western Cape. According to Human Rights Watch, they constituted one of the largest problems for labourers in rural areas. Evictions have followed in the wake of increased seasonalization and casualization of the labour force. Joey Cloete from BAWUSA states that they defend evicted labourers in court at least every month and usually more often than that. In most cases the labourers do not get compensation when they have been evicted. But he does not blame the farmers as much as the courts. In terms of the Extension of Security of Tenure Act of 1997, a court can issue notice of eviction, "if it is satisfied that suitable alternative accommodation is available to the occupier concerned". But he claims that the courts do not adhere to that legislation. ${ }^{362}$

However, even if alternative accommodation is not available, it is possible for courts to grant an order of eviction. But there are some provisions. Firstly, it must be "just and equitable" and it must be certain that there is no suitable accommodation available to the tenant "within a period of nine months after the date of termination of his or her right of residence [...]". Secondly, it must be certain that the "the efficient carrying on of any operation of the owner $[\ldots]$ will be seriously prejudiced unless the dwelling is available for occupation by another person employed or to be em-

\footnotetext{
${ }^{361}$ Human Rights Watch, Aug., 2011.

${ }^{362}$ Government Gazette, Nov. 28, 1997. Extension of Security of Tenure Act, 1997; Joey Cloete, BAWUSA, interview, 2013-12-06.
} 
ployed by the owner [...]". Thirdly, it must be certain that efforts have been made by both owner and occupier to find other accommodation. ${ }^{363}$ It is thus possible for farmers to evict a person on the farm as long as they can prove that the accommodation is intended for another labourer who is required in production. Efforts to find alternative accommodation have probably not always been comprehensive, though.

But there are also other means to use for farmers who are not willing to go to court. Many have used illegal methods such as intimidation and sabotage such as turning off electricity or water in order to get the occupiers of a house to move. In many cases the actual intimidation is conducted by labourers who are loyal to the farmers, for example security guards on farms. In that regard, there is an internal pressure from the community on the farm on the dwellers or occupiers who are not wanted on the farm to move. That form of internal pressure is most likely as effective as outside pressure or intimidation from the farmer. This can be compared with the case in the 1980s on Wickus Stols' farm, where members of the labourers' committee chased another committee member, who abused his wife, off the farm. Stols did thus not have to discipline the labourers, since they did it themselves. ${ }^{364}$ Having loyal labourers is thereby an advantage also when it comes to evicting unwanted people off the farm.

Krige is not the only farmer to try to move the labourers off the farm. Leana Olivier from FARR tells of other cases where it has happened. Some of the labourers might prefer living outside the farm, but doing so has also had implications for their health. One woman, who used to live on a farm but now stays outside of it, eats a less nutritional diet that she did when she was on the farm. On farms the farmers usually slaughter a sheep or a goat at times and give to the labourers. ${ }^{365}$ This is not done on a weekly basis, but perhaps at holidays and certain events such as harvest time. That meat is not provided when the labourer lives off the farm, and it is rather expensive to buy for a farm labourer. Living off the

\footnotetext{
${ }^{363}$ Government Gazette, Nov. 28, 1997. Extension of Security of Tenure Act, 1997.

${ }^{364}$ See Human Rights Watch, Aug., 2011; Farmers' Weekly, Nov. 15, 1985.

${ }^{365}$ Leana Olivier, FARR, interview, 2013-10-29.
} 
farm thereby implies a greater freedom from the farmer, but it also means that all those services and benefits, which are included in the wage for the permanent labourers on the farm, must be paid for by the labourer.

\section{Understanding the isolation - challenges for trade unions}

The close paternal relationship between farmers and labourers has been one important reason behind the low level of trade union organization in agriculture. But there are other aspects, which can also explain why farm labourers are dependent on farmers and do not join unions. Ewert and du Toit note that after 1994, a "paternalist state" has entered the farming sector with legislation aiming to protect labourers and challenged the role of farmers. ${ }^{366}$ However, legislation such as determination of minimum wages has also hampered trade union organization. As Mercia Andrews from TCOE states, there is no reason for farmers to negotiate with unions when the government has already decided minimum wages. This, in turn, means that labourers are not encouraged to organize themselves and actively confront and challenge farmers about wages or living conditions. Andrews explains that the fact that farm labourers "never have to confront their boss about wages" means that they will never be independent. The problem is therefore with the government, which acts in a way that does not promote independence for farm labourers. According to Andrews, the role of the state is not to organize farm labourers, it is to "create conditions" for farm labourers to organize themselves. In that sense, she argues, there is a paternalist approach from the government to take care of the farm labourers' problems for them. ${ }^{367}$

Following Andrews, this approach is counterproductive in terms of improving conditions for farm labourers. But it is certainly not new. We have seen that the governments during the 1940s and 1950s were also concerned about the conditions for farm labourers, or were at least concerned that the poor health of farm labourers threatened the future of farming. But also then there was no expectation that farm labourers themselves were able to solve their

\footnotetext{
${ }^{366}$ Ewert and du Toit, 2003, p. 324.

${ }^{367}$ Mercia Andrews, TCOE, interview, 2013-12-02.
} 
own problems. The government, the Temperance Alliance and farmers all took it upon themselves to discuss the causes and effects of excessive drinking and to find solutions, which was a form of public paternalism. The farm labourers themselves were not even invited to give witness to the various committees investigating the issue of alcoholism in wine regions of the Western Cape. ${ }^{368}$ The ANC government after 1994 has in that sense continued the old tradition of caring for farm labourers instead of allowing farm labourers to care for themselves, which means that the public paternalism has continued into the twenty-first century.

The political situation in the 1940s and 1950s was obviously quite different than the one after 1994. In the 1940s and 1950s, there was no political freedom for black and coloured farm labourers, and the state actively suppressed non-racial trade union organization. But after 1994, the trade union movement, through COSATU, has been in alliance with the ANC government and has had considerable influence. Still, this has not affected the view on farm labourers as unable to improve their own conditions. This view is also reflected in some of the literature, where farm labourers, especially female ones, are described as one of the most vulnerable groups in South Africa. ${ }^{369}$ In many ways that is certainly how their position can be described; farm labourers are often subject to the will of the farmer and their employment is often insecure. But describing farm labourers as "vulnerable" also reproduces the view that they are unable to improve their own conditions.

Instead of telling farm labourers what they need and what to do, Andrews explains that she has tried to reduce the role of TCOE. She says that TCOE used to be a "typical NGO" in the 1990s when it went to the rural areas and said "you need literacy" and then taught literacy. Clearly, aims such as literacy are still important, but according to Andrews, she has tried to give the organization more focus on land rights and farm labour issues. And instead of telling people what they need, she has tried to encourage other organizations, which represent farm labourers, to take more

\footnotetext{
${ }^{368}$ See Cape Coloured Liquor Commission, 1945; Select Committee on the Subject of the Liquor Bill, 1952.

${ }^{369}$ See Falletisch, 2008, pp. 59, 85.
} 
responsibility and assume leadership. And "the leadership must be nurtured", she points out. Organizations such as the trade union CSAAWU and Mayibuye Land Rights Forum, which TCOE work together with, have therefore been given more responsibility. Her opinion is that the "NGO's role is not to substitute for popular movements but to help them grow". ${ }^{370}$ The role of the NGO is thus rather to provide opportunities for such organizations to lead, and to help them to lead and improve conditions for farm labourers.

One reason for the continued view on farm labourers as incapable of improving their own conditions is the low level of unionization. Andrews mentions that COSATU, through FAWU, never has been able to organize farm labourers to any great extent. Ewert and Hamman briefly discuss the reasons for this during the late 1990s and argue that resistance from both farmers and labourers, and labourers' unawareness about their rights, can explain the low level of unionization. ${ }^{371}$ Thus, the unions do not have a model for accessing farms and organizing farm labourers, which is also what Andrews notes. She states that the unions have not been able to understand that farm labourers differ from industrial labourers in urban areas. The labourers on farms are much more isolated from each other and from the outside world than industrial labourers in cities are. But still the farm labour unions have tried to use an industrial model for unionizing in farming, she states. ${ }^{372}$ This has not been helpful.

Union representatives did, however, express ideas about the difficulties of organizing farm labourers already in the early 1990s. The specific conditions in farming were discussed. But at that point the strategy seems to have been to focus on agribusinesses and cooperatives, since it was easier to organize labourers there because the production was covered by labour legislation, whereas family farms were usually outside of legislation. ${ }^{373}$ The apartheid labour legislation thus clearly favoured the family farmers, although even

\footnotetext{
${ }^{370}$ Mercia Andrews, TCOE, interview, 2013-12-02.

${ }^{371}$ Ewert and Hamman, 1999, p. 216.

${ }^{372}$ Mercia Andrews, TCOE, interview, 2013-12-02.

${ }^{373}$ Ball, 1990.
} 
they could have large numbers of employees. After 1993 and 1994, legislation changed, though, so that all farms were included, but the unions have not been able to increase their influence in farming. The isolation of farm labourers is perhaps one of the most important reasons for the lack of unionization. There are some farm labourers who are interested in joining the union, but it is difficult to reach them; the farmers intimidate them and there is less pressure from their fellow farm labourers to join the union and go on strike. Since they live on the farm they do not go home to the township, where there is a greater pressure to join the union or go on strike. The unions have not understood "that level of isolation", according to Andrews.

In addition to the isolation, there is also a racial factor to consider. Joey Cloete notes that the permanent labourers, who are usually coloured, are unwilling to join the union. Cloete argues that unionization is more frequent among the seasonal labourers, who are often black, and who were the main participants in the strikes of 2012 and 2013. These seasonal labourers are also important for recruitment to unions and for communication between the leaders and members of the union. Cloete explains that BAWUSA uses the seasonal labourers to spread messages to labourers on farms. These seasonal labourers are especially important, since it is difficult for the union to get access to farms. However, in those cases where the union has been able to make advancement on farms and bargained with farmers, also the permanent labourers benefit. The coloured, permanent labourers therefore use the black labourers to some extent, according to Cloete, since they side with farmers when the union is weak and benefit from agreements when the union is strong. ${ }^{374}$ But the permanent labourers are not actively supporting the unions, which contributes to a separation between permanent and seasonal labourers, which is, to a great extent, also a racial divide.

During the twenty-first century, the general attitude towards unions among farm labourers in the Western Cape has changed, though, according to Andrews. One reason is that many coloured

\footnotetext{
${ }^{374}$ Joey Cloete, BAWUSA, interview, 2013-12-06.
} 
farm labourers have moved from the farms into townships, especially those dominated by blacks, and have been exposed to attitudes found there. This can be seen in the whole Langeberg region, she notes. ${ }^{375}$ These attitudes include stronger opposition towards employers along class lines, which means a stronger inclination to join unions and go on strike. So, the farmers' strategy to fire labourers and hire them on seasonal contracts has resulted in more radical and militant labourers. In that regard, the isolation of farm labourers has been broken for those who are no longer permanently employed and do not live on the farms. Seasonalization and casualization has thereby not only contributed to a gap between different categories of farm labourers, but also transformed the landscape of unionization towards one where unions are stronger outside the farms, but remain weak and without much influence inside the farm gates.

\section{Farm labourers organizing against trade unions}

While lack of access to farms has hampered unions, an equally big obstacle to successful recruitment of members has been the reluctance of labourers to join them. Kanonkop and Bosman are two examples of farms, where trade unions do not have a foothold nor any influence. Lawrence on Kanonkop mentions that it is good that there are no unions on the farm. In fact, the lack of unions is, according to him, the reason why conditions are better there than on other farms. On the farms where unions are present there are much more problems: "We don't want that in Stellenbosch", he notes. The main issue appears to be the lack of communication between unions and farmers. Such problems do not exist on Kanonkop, where the labourers' committees regularly communicate with the farmer. He says that if there is a problem, "we must deal with it at once" and solve it. ${ }^{376}$

During the strikes in 2012 and 2013, farms such as Kanonkop and Bosman were not directly affected. According to Johann Krige, the labourers came to him during the strikes and asked what they should do. If they had come, he says, the labourers would have

\footnotetext{
${ }^{375}$ Mercia Andrews, TCOE, interview, 2013-12-02.

${ }^{376}$ Lawrence, Kanonkop, interview, 2013-12-11.
} 
"chased them out". He points out that it was the labourers who organized themselves to keep the strikers out and that he himself "only helped with a few things", ${ }^{377}$ although that might be an understatement of his own role. On Bosman, the labourers who stayed outside the farm were told not to come to work during the days of the strike, since they would be targeted by striking labourers as strike breakers. But the labourers still came to the farm. That solidarity with the farm was greatly appreciated by Bosman. Like Krige, Bosman also points out that the labourers were ready to keep the strikers out. However, for safety reasons he kept the labourers out of view from the road and had them working where they could not be seen. ${ }^{378}$

Labourers on farms such as Kanonkop and Bosman thus appear to be very loyal to farmers, or at least find it safer to side with them. Moreover, many farm labourers have also been discontent with the unions. In 2007, farm labourers complained, at least according to Farmers' Weekly, that unions were "self-serving" and that the leaders mainly wanted to enrich themselves. ${ }^{379}$ Both Danie Niemand from the Department of Agriculture and Farmers' Weekly explain that the farm labourers are not interested in joining the unions, since they do not receive support from them after they have become members. Niemand claims that the labourers want organizations that can help them with both labour issues and social issues and argues that unions can only help them with labour issues. In 2008, a new "union", the South African Farm Workers' Association (SAFWA), closely allied with Agri Wes-Cape, was founded. The chairperson, Shawn McKenzie, explained to Farmers' Weekly that the founders previously had been involved in traditional unions for farm labourers, but thought that such unions did not "address the needs of workers in the way we felt they should be addressed". Especially, the founders of SAFWA "wanted to get more involved in the social and economic upliftment of farmworkers". ${ }^{380}$ The overall goal for the organization was to improve productivity

\footnotetext{
377 Johann Krige, Kanonkop, interview, 2013-12-11.

${ }^{378}$ Jannie Bosman, Bosman Family Vineyards, interview, 2013-12-10.

${ }^{379}$ Farmers' Weekly, Aug. 15, 2008.

${ }^{380}$ Farmers' Weekly, Aug. 29, 2008.
} 
in farming, but that could not be accomplished by strikes. Instead, SAFWA wanted to "facilitate the negotiation process". By working closely with farmers and labourers "to identify ways to address the needs of farmworkers", farmers would be able to focus on farming "without having to worry about their workers' wellbeing". ${ }^{381}$

The close relationship with organized agriculture indicated that SAFWA did not aim to disturb the power balance, but the focus on social issues suggests that these issues had been overlooked by labour unions and it is clear that unions do not have programmes for reducing for example alcohol problems. It is likely that unions do not regard such issues to be as important as for example raising the minimum wage and since the dop system has virtually disappeared, they cannot criticize farmers for not complying with legislation. But Nosey Piterse and BAWUSA intended to sue farmers collectively for the alcohol problems among farm labourers in 2008. According to Pieterse, the farmers had a collective responsibility for the high prevalence of FAS among children of farm labourers due to the dop system.

Nosey Pieterse is one of the trade union leaders who have been criticized the most by organized agriculture in the twenty-first century. In 2007, he was accused of embezzling funds, which were supposed to be used for social upliftment programmes, from the South African Wine Trust. Pieterse, however, claimed that he and the union were victims of smear campaigns by the farmers and their allies. ${ }^{382}$ No matter which side is correct in their claims, it is apparent that farm labour and unionization is an arena of heated debate.

In response to the violence during the farm labour strikes, a Farm Worker Forum was established in 2013. One of the convenors was Rita Andreas, who is a farm labourer on Bosman Family Vineyards. Andreas said that the Forum was supported by labourers on most farms in the Berg River municipality and that it would be the "mouthpiece of the farm workers" in the future. According to Andreas, the Forum would give the farm labourers "an oppors

\footnotetext{
${ }^{381}$ Farmers' Weekly, Aug. 29, 2008.

${ }^{382}$ Farmers' Weekly, Jan. 25, 2008; Joey Cloete, BAWUSA, interview, 2013-12-06.
} 
whentunity to represent themselves". ${ }^{383}$ Although the Forum was organized by the labourers, it is apparent that farmers also endorsed it. Jannie Bosman was very proud of Andreas and what she had accomplished. ${ }^{384}$

About one thousand people attended the first mass meeting of the Forum, which explained that it was not interested in the trade unions: "We asked no body to speak for us", Andreas said, indicating that Nosey Pieterse and Tony Ehrenrich were not supported by farm labourers. But it was not only the unions that were blamed, the largest problem was the seasonal labourers and the unemployed, according to Ockert Diedericks, a farm labourer from Wellington and a representative of the Forum. He argued that the strikes could destroy the "good relationships that existed between most permanent workers and their employers [...]". Instead, it was important to "nurture the relationship between farmers and workers" according to Diedericks. His statement also clarifies the relationship between the seasonal labourers and the permanent labourers:

When the harvest is over, seasonal workers go back to where they came from and we stay behind to deal with the broken relationships between farmers and workers that was caused by the actions of seasonal labourers. ${ }^{385}$

There is thus a division between the permanent labourers and the seasonal labourers. Diedericks did, however, not consider the seasonal labourers, who stay on farms, such as wives and children of male labourers. Those were most likely not involved in the strikes.

The division of the labour force is a result of the increasing diversification of labour, which has been ongoing since the 1980s. The permanent labourers, who are mainly coloureds, have become allied with farmers, while the black and coloured seasonal labourers have been largely outside the paternalist relations on farms, and thereby without social security. The division between the two groups of labourers has existed for some time, but was definitely enhanced by the strikes of 2012 and 2013. The problem for the

\footnotetext{
${ }^{383}$ Farmers' Weekly, Jan. 25, 2013 (www.farmersweekly.co.za 2018-12-05).

${ }^{384}$ Jannie Bosman, Bosman Family Vineyards, interview, 2013-12-10.

${ }^{385}$ Farmers' Weekly, Jan. 25, 2013 (www.farmersweekly.co.za, 2018-12-05).
} 
Farm Worker Forum was probably not so much the strike activity in itself or the demand for an increased minimum wage, but that strikes threatened to destroy relations between the farmers and the permanent labourers as well. Similar to how SAFWA in 2008 cooperated with organized agriculture, the Farm Worker Forum did not want to confront farmers, since it feared that the people they represented would also become part of the seasonal labour force, or worse, without work completely. 


\section{THE STRUGGLE OVER FARM LABOURERS - ALCOHOL ABUSE AND SOCIAL UPLIFTMENT IN THE POST-APARTHEID ERA}

\section{Cheap alcohol and the legacy of the dop system}

During the twenty-first century, alcohol abuse among farm labourers in the Western Cape has been described as a legacy of the dop system. ${ }^{386}$ Surely, it cannot be denied that the long-term practice of supplying wine to labourers has contributed to present day problems. However, it is important to note that also other factors than the dop system contribute to alcohol abuse in the twenty-first century.

The demise of the dop system has implied an improvement in labour practices on farms in the sense that farmers do not systematically provide labourers with an addictive substance during their working day anymore. But that does not mean that alcohol abuse is less common now than during the time when the dop system was used. Neither does it mean that farmers are without responsibility for the continued abuse of alcohol in farming areas. One of the largest problems appears to be the availability of cheap liquor, which is prevalent both in farming areas and in cities. Leana Olivier from FARR argues that the availability of liquor in the twentyfirst century is a much bigger problem than the dop system was. ${ }^{387}$

\footnotetext{
${ }^{386}$ See for example Falletisch, 2008; Viall et al. 2011, pp. 132-34; Gossage et al. 2014.

${ }^{387}$ Leana Olivier, FARR, interview, 2013-10-29.
} 
The lack of regulation, and the easy access to alcohol, generates a situation where no one, except those who sell it, has control.

According to Mercia Andrews from TCOE, there is a "big market in cheap alcohol, very cheap alcohol". Some of this is wine, which is made by the farmers or the distillers, but she is not sure exactly how it is made or who is behind it. There is apparently much secrecy around this topic, and Andrews says she does not want to blame anyone until she knows more. However, she concludes that some of the wine sold to labourers has different labels than the ones seen in stores. ${ }^{388}$ It is thus not wine produced for the open market, but for a specific group of consumers: the farm labourers. If the farmers produce this cheap wine, it can definitely be regarded as a continuation of the dop system, since it is produced for the purpose of intoxicating the farm labourers. It can also be regarded as the logical result of market driven solutions; instead of providing the wine for free, some farmers sell it to the labourers, who cannot always afford the more expensive liquor sold in stores.

Some of this cheap wine constitutes what is known as the "papsak", that is, wine sold in large plastic containers. The papsak means larger quantities of alcohol, which serves the purpose of becoming intoxicated. In some aspects it resembles a soft version of the dop system, but the difference is that the role of farmers is not obvious, or is at least not visible. Andrews does not think that the cheap wine is made illegally. It is probably produced legally, but sold through illegal channels. ${ }^{389}$ There is thus a lack of regulation regarding the sale of this wine.

Both during and after apartheid, shebeens have been important points of sale for illegal alcohol. Mager argues that shebeens have been places where blacks have been able to produce their own culture, outside the control of whites and often in opposition to it. ${ }^{390}$ The popularity of shebeens can consequently be explained by their role during the years of white political domination as places of refuge for the oppressed. After 1994, the shebeens have thus continued to be popular because they represent the black and coloured

\footnotetext{
${ }^{388}$ Mercia Andrews, TCOE, interview, 2013-12-02.

${ }^{389}$ Mercia Andrews, TCOE, interview, 2013-12-02.

${ }^{390}$ Mager, 2011, pp. 4-5, 12-13, 70.
} 
cultures, and not the white culture. However, Mager does not consider the economic factors surrounding shebeens. When there was prohibition for blacks, it is likely that shebeen prices were high since they had a monopoly on sale of alcohol to that group. After prohibition it is likely that prices were lowered, since illegal liquor is rarely profitable unless it is cheaper than the legal alternatives. During the past years, many shebeens have become legal, but the majority are still illegal. Lower prices, and the fact that they are easy to access for people who live in townships, must thus be seen as crucial to explain their popularity.

Most shebeens are located in townships in urban areas, but they are also found in rural areas. There are even shebeens on farms, where labourers go to buy illegal liquor. Jannie Bosman explains that there is a shebeen on a farm neighbouring Bosman. The owner has apparently allowed a tenant to reside on a part of the farm and the tenant runs a shebeen in a house or shack there. According to Bosman, shebeens have become more prevalent after the dop system disappeared. ${ }^{391}$ Although Bosman is clear to point out that the dop system was wrong, his statement indicates that the situation in the twenty-first century is not necessarily an improvement. The labourers were perhaps not drinking less when they were given wine, but there was more control over supply and distribution, which was positive from the viewpoint of farmers. Illegal shebeens were, however, frequent in the Western Cape also during the time the dop system was used, but since there was a regulated supply of wine on farms, there was probably less demand for illegal sales.

The continued existence of shebeens must also be explained by the lack of efforts to close them. Mercia Andrews says that she does not hear about the police or government trying to get rid of the shebeens, which contributes to the problem. The government's lack of will to combat shebeens can to a great extent be explained by the economic interests some politicians have in the shebeen industry. Danie Niemand from the Department of Agriculture says that there are many politicians, who own shebeens, but he does not mention who they are. Also Leana Olivier from FARR confirms

\footnotetext{
${ }^{391}$ Jannie Bosman, Bosman Family Vineyards, interview, 2013-12-10.
} 
that many politicians, some of them in parliament, have interests in the illegal liquor trade and therefore are not interested in stopping it.

Despite the prevalence of shebeens, some of which are found on farms, a more severe problem in the farming areas appears to be so called mobile shebeens. The mobile shebeens are run by people driving around to the farms, selling large quantities of alcohol. ${ }^{392}$ Such sales contribute to perpetual alcoholism among people in rural areas who might want to stop drinking. Leana Olivier mentions a case of a woman who worked on a farm and had alcohol problems. The woman explained to Olivier that it was not she who found the alcohol; it was the alcohol that found her. ${ }^{393}$ There was simply no place where the woman could be in an alcohol-free environment. It is not unusual that the illicit sellers allow people to buy on credit and then collect the debt from the customers almost as soon as they have received wages or government grants, which creates a situation where those who are in debt have little money left for food or clothing or for their children and families. Danie Niemand argues that some of those who deliver alcohol to farms are people who live in cities and own shebeens in the rural areas. But he also says that these people charge higher prices, perhaps twice as high as in liquor stores. ${ }^{394}$ The isolation of farm labourers on some farms, especially in the more remote areas, makes it harder for them to go to towns to buy alcohol. This isolation is thus clearly exploited by those in cities, who see business opportunities in the rural areas, where the supply of alcohol is limited, and where the demand appears to be high.

It is, however, not only sellers from urban areas who supply alcohol through mobile shebeens. Also farm labourers and others in their communities themselves take part in selling. The administrator Rebecca on Beyerskloof explains that farm labourers go to a place in Kayamandi, the township in Stellenbosch, where they buy liquor. Thereafter they take it with them and sell it in their own

\footnotetext{
${ }^{392}$ Cf. Viall et al., 2011, pp. 132-33.

${ }^{393}$ Leana Olivier, FARR, interview, 2013-10-29.

${ }^{394}$ Danie Niemand, Department of Agriculture, interview, 2013-11-13.
} 
communities. ${ }^{395}$ This illegal liquor brings an income in addition to their meagre wages, but it also makes them important persons in their communities since many want to buy alcohol. To solve the problem of illegal liquor the police can thus not only focus on finding shebeens, or even the mobile shebeens, they must also find the farm labourers who supply to their friends and others in their communities.

Since the illegal sellers and even the farm labourers themselves take part in the sales of alcohol, it is clear that the context of alcohol and social problems related to it has transformed to some extent since the twentieth century, when farm labourers were supplied with tots of wine. When the farmer controlled the supply, or at least much of it, there was regulation of the amounts, which is not seen when labourers supply to each other or when they buy from those who make profits from illegal liquor. Further, while the farmers were interested in supplying only enough to keep the labourers on the farm, the sellers today do not have the same interest. They sell for profit, whereas farmers gave as part of the wage or for free in order to reach the aim of attracting and retaining the labourers. That system, which was vertical in terms of how it was supplied, was definitely not harmless to labourers, but the horizontal supply of liquor which dominates today, where sales are made illegally, and even from labourer to labourer, for profit, involves even more risks. Those who sell are not interested in how labourers perform their work. Quite the contrary, the more alcohol labourers consume, the better it is for the sellers. This of course also applies to legal liquor stores.

The legacy of the dop system, which appears to be perpetual alcoholism among farm labourers, is definitely a problem. But it is perhaps misleading to call it a legacy of the dop system, since it implies that it is based on the relations between farmers and labourers and that those relations have been reproduced without outside interference. The dop system was based on supply of alcohol as part of the wage, thereby a part of the relations between capital and labour wherein the labour force was exploited in order

\footnotetext{
${ }^{395}$ Rebecca, Beyerskloof, interview, 2013-11-15.
} 
for farmers to accumulate capital. The legacy of that system, continued alcohol dependence, is reproduced through illegally sold alcohol, where other actors than farmers, for example shebeen owners, make profits. The reproduction of conditions, wherein alcohol dependence is the main feature, is thus to a great extent upheld by those outside farming. That does not mean that farmers are without responsibility. Some of them still sell wine to their labourers at a cheaper price, and they also give wine as a reward. It is also likely that they are involved in the production of cheap wine intended for sales to labourers. Farmers can of course make profits from these sales, or benefit indirectly if labourers are tied to the farms as a result of drinking. However, there are probably few farmers today who base their farming on such activities.

The legacy of the dop system, if we want to use that term, is thus that alcohol cannot be traded for labour, only for money, and that farmers are mainly outside the alcohol-money transaction although they can benefit indirectly, since alcoholism among labourers underpins capital-labour relations.

\section{New generation and old habits}

While alcohol has been in focus among scholars concerned with social welfare in rural Western Cape, there are problems with other drugs as well. Primarily tik (methamphetamine) and mandrax (methaqualone) have become popular drugs during the twenty-first century, in addition to dagga (marijuana), which has been popular in South Africa since pre-colonial times. Rebecca on Beyerskloof mentions that tik is a very big problem in farm labour communities. ${ }^{396}$ Drugs such as dagga, tik and mandrax are supplied by gangs, many of them from the Cape Flats. Tony Ehrenreich, COSATU's Western Cape regional secretary, argued in 2010 that the "scourge of tik is a reality of the lives of so many of our people $[\ldots]$ ". The ones who were responsible were the gangs that had declared war on "our people" by selling drugs, according to Ehrenreich. ${ }^{397}$ By using the phrase "our people", which referred to blacks and coloured members of the working class in the town-

\footnotetext{
${ }^{396}$ Rebecca, Beyerskloof, interview, 2013-11-15.

${ }^{397}$ Ehrenreich, 2010, pp. 39-40.
} 
ships, Ehrenreich clearly wanted to demonstrate that drug dealers, who were also from the townships, were not welcome in the community.

Ehrenreich was mainly referring to urban areas, but the problem with tik has increasingly reached also farms. It appears that on farms the choice of drugs is partly a generational question. Tik and mandrax are mainly used by youths and the younger generation. Alcohol is used by all, but is mainly a problem among the older generation. Petrus Bosman thinks that alcohol is not a big problem anymore, at least not compared to what it used to be. It is mainly among the "older guys" that alcohol causes problems, he says. With the younger ones, "soft" drugs such as dagga are common. It is important to reduce abuse of such drugs; otherwise it easily turns into abuse of heavier drugs such as tik, according to Bosman. ${ }^{398}$ It is possible that drugs have become more common on farms due to a conscious effort by dealers. Jannie Bosman thinks that drug dealers regard farms as "soft targets", where it is easy to find buyers, since the labourers are not "street wise". Such views might have some explanatory value, but we must also consider the possibility that drugs come to the farm since there is a demand for it. Bosman mentions that peer pressure could be one reason why the labourers start with drugs. ${ }^{399}$ However, it is likely that the younger generation has replaced alcohol with other drugs. They have not been exposed to alcohol during the working day in the same way as those who worked under the dop system, and do not require it to the same extent. This is partly confirmed by Gossage et al., who noted in 2016 that labourers over the age of 50, at least on one farm, expected dop wine. ${ }^{400}$

The older generation of farm labourers thus seems to have more problems with alcohol than the younger generation. The ones who belong to the older generation now would have been starting as farm labourers in the 1970s or 1980s. At that time the giving of wine for free was more common than the giving of wine as wages. The older generation was thus not so much involved in the dop

\footnotetext{
${ }^{398}$ Petrus Bosman, Bosman Family Vineyards, interview, 2013-12-10.

${ }^{399}$ Jannie Bosman, Bosman Family Vineyards, interview, 2013-12-10.

${ }^{400}$ Gossage, et al., 2014, p.7416.
} 
system as they were involved in a "soft" version of it. Those labourers who have entered their positions during the twenty-first century have probably not been exposed to the giving of alcohol for free to the same extent as those who started as farm labourers in the 1980s. The absence of a system wherein alcohol is supplied on a regular basis therefore appears to have had an impact on alcohol habits. However, the younger generation is not free from substance abuse, which suggests that the reasons for abuse might be more related to the social circumstances than the remunerative practices based on supply of wine. Farm labourers abuse because it is a way of life, or rather because it is a way of coping with life as a farm labourer.

Mercia Andrews argues that the lack of options is one important reason why farm labourers drink. But also the notion that "we drink on the farms" cannot be overlooked, she notes. The fact that drinking is a practice closely related to being a farm labourer, impacts the frequency and quantity of alcohol consumption, which is similar to Falletisch's argument that heavy drinking is socially acceptable on farms. ${ }^{401}$ The social context must, however, also be acknowledged. Rebecca on Beyerskloof emphasizes that people often drink because of the circumstances they are in. They have no jobs and live under poor social conditions. Lawrence on Kanonkop holds the same view. He thinks that, for example, unemployment is an important contributing factor behind excessive drinking. ${ }^{402}$

However, Andrews is not sure if drinking has increased or decreased during the twenty-first century. "It's there, it's ongoing", she says. But she adds to the explanations given by Rebecca and Lawrence and also points out the low self-esteem among farm labourers, and the social isolation, as important reasons behind drinking. ${ }^{403}$ The low self-esteem comes from a long period of subordination and low social mobility of farm labourers and their children. They have become adjusted to a life on the farms, and while there they drink in order to forget about their problems and because it is socially acceptable. But while some practices have re-

\footnotetext{
${ }^{401}$ Mercia Andrews, TCOE, interview, 2013-12-02; See Falletisch, 2008.

${ }^{402}$ Rebecca, Beyerskloof, interview, 2013-11-15; Lawrence, Kanonkop, interview, 2013-11-27.

${ }^{403}$ Mercia Andrews, TCOE, interview, 2013-12-02.
} 
mained the same on farms, there have been changes in the labour process in farming, which has had an impact on labour relations and the role of alcohol. We will therefore return to the question of mechanization and diversification of labourers.

\section{Mechanization, diversification of labourers and alcohol problems}

The implementation of machinery has required a skilled labour force on farms, which has generated a diversification of labourers. Danie Niemand explains that there are three categories of people who live on farms, in addition to farmers. These are permanent labourers, seasonal labourers and farm dwellers. Among the permanent labourers on wine farms there are seven sub-categories, from managers to general labourers and specialized labourers for pruning and irrigation. The permanent labourers are the ones Niemand and the Department of Agriculture are mostly concerned with. They are to a greater extent coloureds, while blacks are usually found among the seasonal labourers. ${ }^{404}$ The permanent labourers are the ones who stay on the farm and thereby receive benefits, which the other categories do not have. The seasonal labourers usually stay outside the farms and only work for cash wages. Farm dwellers on the other hand stay on the farm, but do not get cash wages or benefits.

On Kanonkop, the production of wine is highly industrialized. Since it is an estate, the farm produces its own wine under its own label, but the farmer Johann Krige also buys grapes from other farms, although those grapes cannot be used for estate wine. The wine farming on Kanonkop is mechanized, which Krige mentions is necessary to be able to compete internationally. He wants to mechanize as much of the production as possible. The production of wine on the farm resembles a factory, with conveyor belt, forklifts and a noisy environment at the bottling and packing. Altogether there are about fifteen people working in the various stages of bottling and packing. A few labourers stack bottles in preparation for bottling. One labourer oversees the bottling machine,

\footnotetext{
${ }^{404}$ Danie Niemand, Department of Agriculture, interview, 2013-11-13.
} 
which conducts the bottling. The conveyor belt transports the bottles to a labelling machine, and then to the packing station at the end of the belt. Two labourers conduct the packing of bottles into cases of six bottles each. From there the cases are loaded on a pallet by a labourer and two others wrap them in plastic. Subsequently, a forklift driver transports the pallets to storage. The pace at the bottling machine and packing is high. Thousands of bottles are produced and packed each day. There is no place for drunken labourers in such production.

Krige states that on Kanonkop the situation with farm labour and alcohol use and abuse now is a "completely different picture" compared to how it was in the 1990s. Now the majority do not drink, he says, although he acknowledges that some of them do. But those who drink are "responsible people", who "drink a glass of wine every night". Still, there are some who drink too much, but not because they are alcoholics, but because they do not "have that responsibility". ${ }^{405}$ When Krige claims that the majority do not drink, he probably means that they do not drink in the way that farm labourers did previously, that is, in large quantities and frequently. At least that is how he wants to depict it. He notes that there might be three or four who have drinking problems out of about a hundred people living on the farm. That number is perhaps an understatement in view of the statistics on dangerous levels of drinking among Western Cape farm labourers. ${ }^{406}$ The dangerous levels do, of course, not necessarily mean that the drinking interferes with work, which is of importance to farmers.

On Beyerskloof and Bosman, the same pattern is seen. In 2013, Truter noted that on Beyerskloof there had been no incidents with drunkenness during the previous three or four years. But there used to be some labourers from the "old regime" that were used to drinking much. There were at least three labourers who drank much previously, but now they do not drink at all, according to Anrí Truter. ${ }^{407}$ Petrus Bosman similarly mentioned in 2013 that during the previous years there had only been a few cases where

\footnotetext{
${ }^{405}$ Johann Krige, Kanonkop, interview, 2013-12-11.

${ }^{406}$ See Gossage et al., 2014.

${ }^{407}$ Anrí Truter, Beyerskloof, interview, 2013-11-15.
} 
labourers were not able to work due to drunkenness, but ten years earlier it was a bigger problem. They even had alcohol testers to test the alcohol levels of labourers in order to stop those who were intoxicated from working, but now they do not use them at all. ${ }^{408}$ The number of farm labourers with alcohol problems thus appears to have been reduced during the twenty-first century, at least on farms such as Kanonkop, Bosman and Beyerskloof. It is possible that the farmers portray their farms as success stories, where problems have existed in the past and have been dealt with. But it is also likely that conditions on these farms are actually better than in other places and that improved conditions have resulted in less abuse.

While mechanization is one factor that can explain more sober habits among labourers, it also has a downside socially. Krige intended to invest in a new bottling machine in 2014. The new machine would reduce the number of people involved in bottling from fifteen to four. ${ }^{409}$ Investments could thus result in nine labourers becoming redundant in that part of production. However, Krige explains that he will avoid firing people. The permanent labourers "are the last to go", he notes. ${ }^{410}$ There are, however, also farmers or investors with different strategies. Jannie Bosman explains that there are many big international conglomerates and individual investors, with much capital, that buy farms and do not allow the labourers to stay. He mentions one case where a British investor bought a farm and told the seller that he had to "get rid of his people" before any deal could be done. Bosman condemns such practices: That is "where all the social problems come from", he states. ${ }^{411}$ The accumulation of capital and consolidation of capital into fewer hands, whereof many are foreign, has thus contributed to the increasing level of seasonal and casual labourers and farm dwellers, who have no place to go except for the houses of family members on farms or in informal settlements.

\footnotetext{
${ }^{408}$ Petrus Bosman, Bosman Family Vineyards, interview, 2013-12-10.

${ }^{409}$ Lawrence, Kanonkop, interview, 2013-11-27.

${ }^{410}$ Johann Krige, Kanonkop, interview, 2013-12-10.

${ }^{411}$ Jannie Bosman, Bosman Family Vineyards, interview, 2013-12-10.
} 
These farm dwellers seem to be causing more problems than labourers do. Lawrence notes that the problems on the farm neighbouring Kanonkop are to a great extent related to the high number of people, who do not work on the farm, but who come to stay there with family members. They are involved in both drinking and drugs, and cause problems in general, according to Lawrence. ${ }^{412}$ These people possibly work as seasonal or casual labourers, but are not employed throughout the year.

On Bosman, there are also some people who do not work permanently on the farm although some of them are seasonally employed. Petrus Bosman reveals that there can be problems with them, for example with drinking or drugs, but he does not consider having dwellers to be a problem. At least not as long as their share is quite low. If about three or five per cent of the houses on a farm have dwellers it is not a problem, but if that number increases to twenty or thirty per cent, then it constitutes a problem, he argues. ${ }^{413}$ Since the dwellers are usually family members, perhaps grown-up children who are unemployed or work elsewhere than on the farm, it is important to also consider how the families will be affected. Clearly, allowing some of the labourers to keep unemployed family members can generate increased loyalty in return. It is thus not only a disadvantage for farmers when dwellers stay on the farm.

Also Danie Niemand suggests that the farm dwellers are the ones who cause the most problems for farmers, since they "abuse the system" and in some cases they want farmers to pay electricity and water for them. He notes that they are not regarded as farm labourers, because they do not contribute to the farm's income. ${ }^{414}$ Still, they rent space on the farms, and thus constitute part of the farm labour communities. Some of them also make up part of the seasonal or casual labour force, which means that they actually contribute to the farm's income, but they are not covered by the social security provided by farmers to the permanent labourers.

\footnotetext{
${ }^{412}$ Lawrence, Kanonkop, interview, 2013-11-27.

${ }^{413}$ Petrus Bosman, Bosman Family Vineyards, interview, 2013-12-10.

${ }^{414}$ Danie Niemand, Department of Agriculture, interview, 2013-11-13.
} 
The position of dwellers is thus worse in comparison to that of the permanent labourers.

Niemand claims that the farm dwellers are often used by politicians and the media to argue that conditions on farms are poor. ${ }^{415}$ Even though there might be others than the dwellers who suffer from poor conditions on farms, it is likely that conditions for them are worse than for others, primarily because they are not regarded as farm labourers and therefore do not receive the benefits that permanent labourers have in the form of free water, sanitation, electricity, medical care or education fees. Such conditions can clearly enhance problems with alcohol, since there is little or no social security for the farm dwellers outside of their families. A labourer on Kanonkop explains that the dwellers are the ones who drink most, but since they do not work, they have steal to get money. ${ }^{416}$ Thefts, but also illegal sale of liquor, could be the only available income for many farm dwellers. Their lack of options and addiction thereby force them into crime, which affects also other inhabitants on farms.

Fewer alcohol problems among permanent labourers cannot only be explained by their closer relationship with farmers and the benefits they receive. More importantly, they cannot be drunk when they work. Machinery and work with, for example, pruning does not allow for drunkenness among the labourers. The permanent labourers are more often responsible for such work operations. But that does not mean that they have stopped drinking completely. During weekends they can still drink, and they drink in large quantities. ${ }^{417}$ The binge drinking on weekends was regarded as a main problem by farmers already in the 1950s. In that regard, there has thus been little change. The weekend drinking in the 1950s was, however, accompanied by tots of wine during the working day, which kept labourers in a dazed state most of the time. The disappearance of the dop system has obviously meant that alcohol consumption during the working day has been reduced, but it does not appear to have had an impact on the week-

\footnotetext{
${ }^{415}$ Danie Niemand, Department of Agriculture, interview, 2013-11-13.

${ }^{416}$ Victoria, labourer, Kanonkop, interview, 2013-11-27

${ }^{417}$ Rebecca, Beyerskloof, interview 2013-11-15; Mercia Andrews, TCOE, interview 2013-12-02.
} 
end drinking. Social factors such as tradition, poor education and low expectations of what the future holds must be brought forth as central explanations to the continued alcohol problems.

For the individual farm labourer, the role of alcohol has thus not changed much. It is still a means of escape from life as a farm labourer, and, to speak with Hobsbawm, "the quickest way" out of the winelands. ${ }^{418}$ But the conditions under which they drink are different. Some of them, like those on Kanonkop, can be supplied by the farmer if they are responsible and do not overindulge, in other words, if their drinking does not interfere with work. Others, who are not considered to be responsible, which probably means that their drinking could interfere with work, have to find other supplies of alcohol. It is likely that they are next in line to become seasonal labourers or farm dwellers.

\section{Benefactors and the role of the individual}

The attempts to reduce drinking in rural areas of the Western Cape has mainly been conducted by NGOs such as Dopstop, FasFacts, FARR and TCOE. But also individual farmers have taken initiatives. One farmer, who has focused on reducing at least the effects of drinking, is Beyers Truter. In 2005, he started the FAITH (Foetal Alcohol Syndrome \& Interrelated Treatment Help) Fund. The aim of the fund is to educate especially women of the dangers of drinking while being pregnant, and thus has a focus on Foetal Alcohol Syndrome (FAS). According to Truter, he started the fund because he had realized that while he himself had been fortunate and become successful as a producer of alcohol and has had a good life as a wine farmer, "there is a negative side as well. One of the most negative things is FAS." The desire to inform about FAS was not born out of conditions on his own farm, though, but more from a general perspective, he explains. The focus of the fund is on rural communities, and specifically farm labourers. ${ }^{419}$

While FAS is a problem in many parts of the world, the highest prevalence has been found in South Africa. The relation between the dop system and FAS is often made, and it is likely that the dop

\footnotetext{
${ }^{418}$ See Hobsbawm, 1996, p. 202.

${ }^{419}$ FAITH Fund Leaflet.; Beyers Truter, Beyerskloof, interview, 2013-11-26.
} 
system has affected the frequency with which FAS occurs, but there is no certain relation between the two. ${ }^{420}$ According to Leana Olivier, one reason for the public view that there is a relationship is the fact that the initial research on FAS in South Africa was conducted in the wine farming areas, where the dop system had been prevalent. ${ }^{421}$ The FAITH Fund does not connect FAS with wine farming and can consequently not be regarded as admission of guilt for the alcohol problems in the region. Still, Truter acknowledges that the product he produces is harmful to some. ${ }^{422}$

The FAITH Fund works together with the Foundation for Alcohol Related Research (FARR). According to Truter, the fund "uses" FARR and Leana Olivier, since she has extensive knowledge about FAS. The fund raising is, however, mainly done by Truter himself. Each year he hosts a wine auction on Beyerskloof, from which the proceeds go directly to the fund. In 2012, the auction raised about R150,000. In addition to the auction, part of the income from sales of some wines from the farm also goes to the fund. The money is used for funding of schools and various projects. But the main work of the fund is to "go to farms and talk to people". ${ }^{423}$ There is a team of four people, who conduct most of the work. The administrator Rebecca on Beyerskloof is one of them. She says that she has seen many of the problems with FAS at close hand in her own community at Elsenburg. The team goes to farms after work and visit people's houses. They inform about FAS and alcohol abuse for about ten minutes per house. ${ }^{424}$

Most farmers welcome the team, Rebecca says, which is important to underline, since representatives of trade unions find it very difficult to gain access to farms. If the information from the FAITH team is to reach farm labourers, it is clearly important that they can get access to farms, since the personal contact is the main means of communication. In this regard, it is certainly important that the FAITH Fund is associated with the name of Beyers Truter, who is well-known throughout the wine regions of the Western

\footnotetext{
${ }^{420}$ D. Viljoen, FARR, quoted in Viall et al., 2011.

${ }^{421}$ Leana Olivier, FARR, interview, 2013-10-29.

${ }^{422}$ Beyers Truter, Beyerskloof, interview, 2013-11-26.

${ }^{423}$ Beyers Truter, Beyerskloof, interview, 2013-11-26.

${ }^{424}$ Rebecca, Beyerskloof, interview, 2013-11-15.
} 
Cape. Few wine farmers would probably refuse entrance to their farms for Truter's team. Welcoming information in this way is also a matter of peer pressure. If a farmer says no, and does not want his labourers informed about FAS, he will most likely not be regarded highly by other farmers who see themselves as progressive. The peer pressure exerted through the FAITH Fund resembles the situation when the KWV denounced the use of the dop system in 1997. Although the denouncement was done more out of concern for exports than for the health of farm labourers, it implied a pressure from the top level that the dop system was not something wine farmers should be associated with and that its continued occurrence would be an embarrassment for the entire industry. Truter's FAITH Fund has the same function. Those who do not welcome information about FAS are an embarrassment to other farmers.

The FAITH Fund team does not only visit people in their homes, though. Rebecca mentions that they also visit churches, since they can reach many people at the same time there, and schools. It is especially important to reach the young people, she says. Many children have parents who drink excessively and they easily follow in their footsteps because they think that it is normal behaviour. In order to change such behaviour, the mind-set of people must be changed, notes Rebecca. This does not only involve the women who drink, but also their husbands and families. Also grandparents should be involved and take more responsibility for the grandchildren if the parents cannot do it. On one farm they visited there was a woman who drank while she was pregnant. They pleaded with her to stop drinking, but she did not want to. The woman argued that since her husband was drinking, she would also drink. ${ }^{425}$ There was thus no support in the house for the woman to stop drinking, which is crucial. The team, however, has limited resources and in the end it is the people who drink, who must take the initiative to stop, she says. When people do not want to listen to their advice, there is not much they can do. ${ }^{426}$

\footnotetext{
${ }^{425}$ Rebecca, Beyerskloof, interview, 2013-11-15.

${ }^{426}$ Rebecca, Beyerskloof, interview, 2013-11-15.
} 
The FAITH Fund, as the name implies, is based on religious values. Change of mind-set must come through adherence to Christianity. Truter even mentions that the purpose of the fund is not only to educate about FAS, but also to "get the Lord's name out there" ${ }^{427}$ In a religious country such as South Africa, that is perhaps not surprising, and it follows the tradition of the Temperance Alliance during the mid-twentieth century and earlier. Religion continues to be a central component in the fight against alcohol abuse. But while the Temperance Alliance was outside farming, and criticized farmers for using the dop system and creating drunkenness among the labourers, at least until the 1950s, Truter acts from the inside and has the perspective of the farmer. The connection to Truter guarantees the fund access to most farm labourers' houses, but it also means that the power relations between farmers and labourers remain intact. Instead of questioning the circumstances leading to abuse, the fund focuses on changing the mind-set of the individual, which is not irrelevant, but only includes a part of the reasons why people drink. The fund does, for example, inform that South Africa is the country with the highest prevalence of FAS, but does not mention that it is almost exclusively found in poor communities. ${ }^{428}$

The individualization of the problem, which leaves most of the burden at the doorstep of the abuser, is in line with other trends in farming and society in general. Through the fund, Truter is thus able to control how FAS is discussed by those who are affected by it. The information provided by the fund should definitely be regarded as beneficial to those who are affected and are at risk of having children with FAS, but this also means that Truter becomes the benefactor, the paternal figure who helps those who are not so fortunate. The mechanisms behind the relations between the benefactor and those who benefit are not revealed, though.

Truters' influence in matters related to FAS must at least partly be explained by the absence of alternative organizations and the absence of the state. In the stead of the state, farmers become the

\footnotetext{
${ }^{427}$ Beyers Truter, Beyerskloof, interview, 2013-11-26.

${ }^{428}$ See FAITH Fund Leaflet, also http://www.faithfund.co.za/what-is-foetal-alcohol-syndrome/ (2014-11-17).
} 
most important benefactors. Petrus Bosman argues that in developing countries such as South Africa there is no social security, there is only the farmer and the family to take responsibility and help those who have problems. Also Danie Niemand refers to South Africa as "developing" and uses it as an explanation for the poor conditions. ${ }^{429}$ While parts of South Africa are certainly poor and can be characterized as "developing", there are also many affluent areas. For the individual farmers and labourers, this view of the country as developing has consequences. To some extent, it can be compared with Falletisch's argument that farm labourers are absolved of responsibility for their drinking because of its origin in slavery and paternalism. ${ }^{430}$ When individual farmers take social responsibility, they are in one way correcting the historical inequalities. If they manage to improve conditions, they will be credited, for example by organizations such as Fairtrade and the KWV. But if conditions remain the same they cannot be criticized, since poor conditions are expected in developing countries. Attempting to improve conditions is thus a win-win situation for farmers.

\section{Upliftment, empowerment and fairness}

Most farmers are not involved in work to reduce alcohol related problems among labourers to the same extent as Beyers Truter is with his fund. But some have been active on their own farms with upliftment programmes and social activities for labourers. In 2002, the wine farmers' journal Wineland reported on initiatives taken by wine farmers to improve conditions on their farms. For example, Francois Malan at Simonsig spent R750,000 that year to improve housing for labourers. Training for labourers in, for example, prevention of alcohol abuse and conflict handling was also undertaken. Child care for labourers' children was another project, which aimed at social upliftment on the farm. But also sports activities were an important component in that work. ${ }^{431}$ This is seen on other farms as well. On Kanonkop there are, for example, two football fields for the labourers. They play tournaments against teams

\footnotetext{
${ }^{429}$ Danie Niemand, Department of Agriculture, interview, 2013-11-13.

${ }^{430}$ See Falletisch, 2008, p. 191.

${ }^{431}$ Wineland, July, 2002.
} 
from other farms on weekends and they practice one day a week. Johann Krige declares that sports has a positive impact, it keeps them fit and it "keeps them busy". ${ }^{432}$ This is especially important for the young people. The tournaments where Kanonkop labourers play against teams from other farms are apparently healthy for the labourers, but it is also a way to intensify the relationship between labourers and the farm. When the labourers play against teams from other farms they represent Kanonkop, which gives them an identity as people from Kanonkop and that they belong to the "Kanonkop family", which is how Krige refers to the farm and the people who work there.

Football is mainly played by the men, but Krige mentions that netball, which is popular among women, is also played on the farm. On Bosman, there are, however, a number of different clubs; a social club, a men's club, a women's club and a youth club. In addition, there is also a variety of sports activities. Also on Bosman the purpose of the sports and various clubs is to keep people busy in their leisure time. The social activities thus provide alternatives to drinking. Petrus Bosman is of the opinion that the activities have been successful. But social upliftment is not only about social activities. On his farm they have courses for labourers in literacy, numeracy and personal finance, or financial literacy as Bosman calls it. Such skills are lacking among many labourers, according to him. ${ }^{433}$

Personal finance skills are perhaps especially important. It appears that there is a focus on it throughout the Western Cape farming regions. ${ }^{434}$ During the past ten years, the main problem among farm labourers on the farm has been indebtedness, says Bosman, who argues that problems with indebtedness are worse than those with alcohol. The labourers borrow money from both loan sharks and commercial banks, who are willing to lend money to farm labourers, especially when they see that wages are increasing. However, farm labourers have problems paying back the money, and

\footnotetext{
${ }^{432}$ Johann Krige, Kanonkop, interview, 2013-12-11.

${ }^{433}$ Petrus Bosman, Bosman Family Vineyards, interview, 2013-12-10.

${ }^{434}$ Danie Niemand, Department of Agriculture, interview, 2013-11-13.
} 
they get caught in a "debt trap". ${ }^{435}$ Also various stores offer credit, which one debt collector described as a "large-scale targeting of farmworkers". Derek Clift, a farmer outside Paarl, explained further how "big chain stores exploit farmworkers' lack of financial knowledge", for example through additional insurance for products. Clift explained that the labourers think they buy a TV for R2,000, but when "everything has been paid off they will have paid R5,000". ${ }^{436}$ As an alternative, Clift offered his labourers to buy the product they wanted for them and then deduct the cost from their wages, which is a typical example of how the paternalist practices continue on farms. It keeps labourers on farms, since they have to work off the debt through the deductions and it also reproduces the relationship based on the farmer as a parental figure who helps the labourers. Not all Clift's labourers accepted his offer, though. Those who refused and instead accepted the store credit were perhaps not so much interested in the credit as in the freedom it implied to buy something without the aid of the farmer. Purchasing things independently on credit thereby becomes a way of escaping the dependence on farmers.

The course in personal finance on Bosman is one method of reducing the problems with indebtedness. Daleen Turner, a consultant who is hired to run courses on the farm, explains that on Bosman they do "real empowerment". The projects are meant to uplift the labourers, but also to empower them as individuals. On many other farms, upliftment or empowerment is only done on a small scale and does not have an impact, according to Turner. ${ }^{437}$ The personal finance course on Bosman can be regarded as "real empowerment", since it provides labourers with means to handle their own lives and not be dependent on the farmer. But the rationale behind such a course implies that the only way for labourers to have more money in their pockets is to spend less, not bargain for higher wages. In that regard, the course entrenches the relations on the farm.

\footnotetext{
${ }^{435}$ Petrus Bosman, Bosman Family Vineyards, interview, 2013-12-10.

${ }^{436}$ Farmers' Weekly, Aug. 15, 2008.

${ }^{437}$ Daleen Turner, consultant, Bosman Family Vineyards, interview, 2013-12-10.
} 
Another "real empowerment" projects on Bosman is the Adama Trust, which is owned by the labourers and which receives part of the profits of the farm. The social upliftment and empowerment is definitely an important part of the Bosman farm. The farm has formed the largest Black Economic Empowerment (BEE) deal in South Africa "to date" together with the Adama Workers Trust. ${ }^{438}$ Petrus Bosman explains that the Bosman family actually regards the farm as belonging to the "community". ${ }^{439}$ In this view, the "Bosman family" is thus the people who own and work on the farm, and the owners merely custodians of land.

While upliftment and empowerment projects surely have aided many farm labour communities, it appears that they have also become a way for farmers to market the farm and its products. The Fairtrade label has certainly contributed to this trend. According to Danie Niemand, South Africa is the country in the world with the largest number of farm labourers working on Fairtrade certified farms. ${ }^{440}$ Obviously, farmers in South Africa have realized the profit potential in being "fair". Bosman explains that since the farm started with a "multi-ownership model" in 2009 the economic growth has been threefold. The turnover of the farm in 2013 was R85 million. ${ }^{441}$ Although fairness has become a marketing tool, it has also generated transformations for the labourers on farms. In order to retain the Fairtrade certificate, the farm must be inspected at least once a year, which makes it hard for farmers not to maintain for example houses.

\section{Treatment and coordination of efforts}

Already in 1994, the ANC targeted alcohol and drug abuse as a central concern for the transformation of South Africa into greater equality. Several strategies were also launched during the following years, but there appears to have been a discrepancy between policy and implementation. Lack of coordination of efforts and lack of funding have been brought forth by Parry and Bennetts as explana-

\footnotetext{
${ }^{438}$ http://www.bosmanwines.com/estate/bee.html (2014-05-14).

${ }_{439}$ Petrus Bosman, Bosman Family Vineyards, interview, 2013-12-10.

${ }^{440}$ Danie Niemand, Department of Agriculture, 2013-11-13.

${ }^{441}$ Petrus Bosman, Bosman Family Vineyards, interview, 2013-12-10.
} 
tions for the discrepancy and poor success rate of strategies to reduce alcohol and drug abuse. ${ }^{442}$ There are, however, initiatives taken by both individuals and the Western Cape government.

On Beyerskloof and on Bosman the farmers state that those labourers who have severe alcohol problems are sent to rehabilitation centres. But they are very few, Truter mentions only one case where it has happened. However, on Bosman, the success rate for labourers who have been sent to rehab has been fairly good, although it has not been "one hundred per cent". Petrus Bosman explains that there have been some cases where it did not work. In those cases they try again, but the labourers only get three chances. If their drinking causes problems they get a warning, if it happens again they get a second warning and the third time they get fired. But on Bosman they want to avoid firing people, mainly because it can generate other social problems such as drug abuse. ${ }^{443}$

The farm pays for the expenses at rehab centres, says both Truter and Bosman. Truter explains that many farmers do it, at least on the "good farms". But they seem to pay only for the "good workers", ${ }^{444}$ thus the ones they think are worth the effort and the expense. In order to get treatment for alcohol abuse, it is thus apparent that the labourers must be on good terms with the farmer. It appears that farm managers are more likely to be involved in rehab. At the Hesketh King Treatment Centre outside Stellenbosch, run by the Salvation Army, there was one farm manager in May 2014, whose treatment was paid by the farm. But there were not many farm labourers "as such" in the programme. ${ }^{445}$ It is possible that the alcohol problems among farm labourers are not always regarded as problems by either labourers themselves or by farmers, which can explain why few labourers are involved in treatment.

While there are few treatment centres funded by the government, it has at least acknowledged that there is a problem with alcohol and drug abuse in the Western Cape. In 2007, a Western Cape alcohol and drug abuse summit was organized by the Department of

\footnotetext{
${ }^{442}$ Parry, 1998, pp. 10-12, 199, 214.

${ }^{443}$ Petrus Bosman, Bosman Family Vineyards, interview, 2013-12-10.

${ }^{444}$ Anrí Truter, Beyerskloof, interview, 2013-11-15.

${ }^{445}$ Amelia Oberholzer, Hesketh King, personal communication, 2014-05-12.
} 
Agriculture. The summit was attended by 250 representatives of 17 organisations such as Dopstop, FasFacts, Women on Farms, Bawsi and Agri Wes-Cape. The summit generated the establishment of a forum for alcohol and substance abuse, led by the Western Cape Department of Agriculture. According to the then Western Cape Minister of Agriculture, Cobus Dowry, the aim of the forum was to "coordinate the attempts of all who aim to uplift farmworkers". Dowry did not specify which attempts he referred to, but it appears that the measures taken to reduce alcohol and drug abuse were not evenly spread in the Western Cape: The forum "should avoid duplicating efforts in some areas while there is little or no attention in other areas". ${ }^{446}$ The following year, in 2008, Dowry approved a "framework and coordinating structure for the Western Cape Department of Agriculture's Mini-Drug Master Plan”. The Mini-Drug Master Plan was part of the National Drug Master Plan, which "mandates all government departments to develop programmes to facilitate access to quality and affordable substance abuse treatment services". Dowry approved R200,000 for the plan. The forum was to "oversee and evaluate service providers charged with the implementation of a mini-drug plan". This included prevention programmes, treatment and research.

The Department of Agriculture also committed itself to fund the forum by setting aside 5 per cent of the funding marked for support for farm labourers to "organisations and service providers for substance abuse prevention, intervention or research initiatives". ${ }^{447}$ The ones responsible for the actual work were thus the NGOs, which could apply for funding from the Department of Agriculture. Danie Niemand explains that in 2013 the Department of Agriculture funded about twelve or fifteen projects carried out by NGOs. All efforts to reduce alcohol and drug abuse among farm labourers are thus based on the initiatives taken by NGOs, which has implications for those who are in need of help. The farm labourers with alcohol problems and who want help thus have to rely on living in an area, where there is an NGO with a specific project regarding alcohol abuse.

\footnotetext{
${ }^{446}$ Farmers' Weekly, July 27, 2007.

${ }^{447}$ Farmers' Weekly, Oct. 31, 2008.
} 
After 2008, the Democratic Alliance (DA), which governs the Western Cape, has initiated additional programmes for the prevention of substance abuse. Danie Niemand claims that the Western Cape is the province in South Africa where the work to reduce abuse among farm labourers has reached furthest. The other provinces are doing very little in comparison, he says. ${ }^{448}$ The programmes in the Western Cape are thus leading the way insofar as the problems with alcohol abuse are acknowledged and that funding is allocated to reduce the problems. Mercia Andrews from TCOE is more critical, though, and says that the "government is doing nothing in the rural areas in any case". The success rate of the government programmes is uncertain, so we do not know the number of people that are actually reached by them. ${ }^{449}$ Not all initiatives have been started by the DA, though. The Western Cape forum on substance abuse, for example, began when the ANC was in power, and was, according to Farmers' Weekly, initiated because of the high incidence of FAS and crimes related to alcohol. ${ }^{450}$

While the Western Cape government has taken initiatives to reduce alcohol and drug problems, its role has been that of funder and coordinator of activities already conducted by NGOs. In that regard, the measures taken by the government can be characterized as assistance to expertise in the field. But the government has not been very active in finding new solutions to problems that are specific to the farm labourers or the agricultural sector, for example by reducing the illegal liquor.

\section{The voice of farm labourers}

While farmers and NGOs have been responsible for various projects aiming at social upliftment and reducing alcohol abuse, the farm labourers themselves have rarely been at the centre of the initiatives. There has been a paternalist approach, as Mercia Andrews explains. The state, through NGOs, has wanted to solve problems for them by uplifting them, which exemplifies the public paternalism that surrounds farm labour. There is literally a parental-like

\footnotetext{
${ }^{448}$ Danie Niemand, Department of Agriculture, interview, 2013-11-13.

${ }^{449}$ Mercia Andrews, TCOE, interview, 2013-12-02.

${ }^{450}$ Farmers' Weekly, Oct. 31, 2008.
} 
approach where the state, farmers and NGOs aim to lift the farm labourers to a higher social level, which is usually never specified, but still exists in the minds of those who make decisions. However, the farm labourers have also taken initiatives to improve their own situation.

An example of initiatives by labourers themselves is the annual gospel festival held at Kanonkop. One of the organizers is Lawrence, who works on the farm. He explains that the purpose of the festival is to arrange something which farm labourers can feel proud of and which offers a different view of farm labourers, both for themselves and for the public. The festival started in 2006. It is always held at the Kanonkop football fields. Lawrence explains that previously there was nothing for farm labourers to do. Since many of them like singing, he thought it was a good idea to start a gospel festival. Although the festival is not exclusively for farm labourers, about 90 per cent of the visitors are farm labourers. The festival is for the entire family, so also children attend. Lawrence explains that the festival is a place where families from different farms can meet. It is perhaps one of the few times during the year when farm labour families from different farms and regions can meet. There are also braais (barbecues) and health stalls where people can get check-ups and advice from nurses. Alcohol and drugs are not allowed at the festival, although some people are drunk when they arrive. Lawrence notes that he wants to send the message to others that farm labourers can have fun and enjoy themselves also without alcohol. ${ }^{451}$

The first year of the festival, about 250 people attended it, but in 2013 more than 4,000 people came. Farmers send their labourers in buses to Kanonkop to attend, even from as far away as Ceres. ${ }^{452}$ Judging by the number of visitors to the festival, it is popular both among farm labourers and farmers, who transport them there. Since it is held on Kanonkop, Johann Krige, of course, also endorses it, which indicates that he sees a value in the festival as such and in being associated with it. The religious component of the festival, for example, is something that farmers can easily support. Both

\footnotetext{
${ }^{451}$ Lawrence, Kanonkop, interview, 2013-11-27.

${ }^{452}$ Lawrence, Kanonkop, interview, 2013-11-27.
} 
farmers and farm labourers, like many other groups in South Afri$\mathrm{ca}$, are usually religious. Religion therefore unites, rather than separates, farmers and labourers. The non-alcohol policy is clearly also something farmers can endorse, since it shows that they support sober activities. From the labourers' point of view, it appears that the festival is an example of how they can organize themselves or at least organize activities for themselves. But while the festival is organized by farm labourers, its existence depends on the goodwill and donations made by farmers and others. The approval of farmers is thus required, which means that this form of farm labour organization is regarded as positive by farmers, while other forms of organization are not approved of. The gospel festival sends signals that farm labourers can arrange large events without the involvement of trade unions. It is organization on terms that farmers can support.

While trade unions have had little success in organizing farm labourers, there have been other organizations claiming to represent farm labourers since the beginning of the twenty-first century. The Western Cape Farm Workers' Association was founded in 2000. It was reported to have 35,000 members at that time. According to Wineland, the reason the association was founded was that farm labourers had not been able to voice their needs in the past. Others had done it for them, and they had realized that "the only access to funds and resources that could help them improve their conditions lies in the mobilisation and organisation from among their ranks". However, it was important that it "should be done outside the trade union ambit - not involving negotiations with employers, not agitating for strike or boycott action [...]". ${ }^{453}$ It is, however, not clear how the association intended to improve conditions, and since it was not even interested in negotiating with farmers it is rather obvious that it was very much an organization that farmers would endorse.

But the lack of will to challenge farmers does not mean that the association did not have an agenda to improve conditions. Koos Badjies, one of the leaders, explained to Wineland that he had been

${ }^{453}$ Wineland, Nov. 2, 2000. 
involved with alcohol and drugs for a long time and thus had firsthand experience of the problems that many farm labourers have. The association had a list of things it meant was crucial to adhere to in order to improve the conditions for farm labourers. The most important thing was education and training, which was followed by gender issues, housing, legislation, youth and health issues, remuneration, economic empowerment, alcohol and drugs and seasonal labourers. However, the issue of wages was not on the list of demands. Another leader of the association, Chris Diedrichs, said that the minimum wage was not included, because the "issue was so sensitive that they feared there might be job losses once employers were pressurised to implement it". ${ }^{454}$ The association thus resembled the committees found on many farms in the sense that it represented the labourers, but could not pressure the farmers to comply with their demands. Instead it wanted to become incorporated into the existing power structure which was seen as the natural order on farms. The cause of farm labourers would thus be promoted from within and through discussions, not through confrontations with, or demands on, farmers.

Since the establishment of the Western Cape Farm Workers' Association, the Western Cape government and farmers have realized the importance of giving recognition to farm labourers and giving them their own forum. The emphasis is on giving. In 2005, the Department of Agriculture became involved financially in the "Farm Worker of the Year" competition. Its focus was to recognize skills among the farm labourers through a competition. The department funded the competition together with the large insurance company Sanlam until 2010, when the company withdrew. The supermarket chain Shoprite became the new sponsor in 2012. Shoprite donates R750,000 to the competition, and the Department of Agriculture funds the other half of the total budget of R1.5 million. The award is handed out annually, usually in Cape Town, at an event where about 750 guests, including the Western Cape Minister of Agriculture and other dignitaries, attend. Niemand describes it as the "flag ship project" of the Department of Agriculture, but also as the big-

\footnotetext{
${ }^{454}$ Wineland, Nov. 2, 2000.
} 
gest event of the Western Cape government during the year. ${ }^{455}$ It is certainly a big event for the farm labourers who attend. They stay in a hotel and live a luxury life compared to what they experience on the farms. Leana Olivier agrees that it is a special occasion for the farm labourers, who usually do not go to Cape Town even though they might live less than an hour's drive away. ${ }^{456}$

According to Niemand, the competition is an important part of the social upliftment of farm labourers in the Western Cape. The competition recognizes the farm labourers for their "part in the agricultural chain". But it also gives them an opportunity to measure themselves with others, which is positive in itself, according to Niemand, who argues that "competition is healthy". ${ }^{457}$ In that regard, the competition follows the trend that started in the 1980s, which aimed at recognizing and rewarding the skilled labourers. In some sense that trend has reached another level, when the state recognizes and rewards the skills of labourers. It is possible to argue that the diversification and stratification of labourers has reached its pinnacle with the Farm Worker of the Year competition, since it actively endorses competition between farm labourers and thereby implicitly a stratification of them. The categories in the competition are general worker, tractor driver, administrative staff, animal production, technical operator, irrigation specialist, junior, middle and senior management. ${ }^{458}$ These are all part of the permanent labour force on farms and are the ones that are recognized for their skills. It is no surprise that the seasonal labourers, who constitute about half of the total farm labour force in the Western Cape, are not included.

Niemand suggests that the winner becomes an "ambassador" for farm labourers, and thus a person whom others look up to. While the honour of winning might be important to the individual labourer, there is also a monetary prize. In 2011, winners of the regional competitions received $\mathrm{R} 1,500$ and the provincial winner received R20,000 and in addition a course sponsored by Stellenbosch

\footnotetext{
${ }^{455}$ Danie Niemand, Department of Agriculture, interview, 2013-11-13.

${ }^{456}$ Leana Olivier, FARR, interview, 2013-10-29.

${ }^{457}$ Danie Niemand, Department of Agriculture, interview, 2013-11-13.

${ }_{458}$ http://www.westerncape.gov.za/general-publication/provincial-farm-worker-year-competition, 2014-05-20
} 
university and a study tour abroad, each worth R40,000. The $\mathrm{R} 20,000$ in prize money was more than the yearly minimum wage in 2012 of $\mathrm{R} 18,047 .{ }^{459}$ Winning the competition is therefore a great opportunity for the individual labourer to receive additional income and to improve his or her skills through further studies. But the winner also becomes part of the Minister of Agriculture's Farm Worker Forum, on which the winners of the past few years serve as advisors to the Minister. The winner in 2010, Christo Somers, wanted to raise the issues of living conditions and medical care for farm labourers at the forum. ${ }^{460}$

The winners of the competition thus have a possibility to impact government policy on farm labour. They give farm labourers a voice in the public arena. But they do not appear to favour independence from farmers for farm labourers. Anthonie Visagie, a farm manager, who won the competition in 2005, was concerned about the antagonism between farmers and farm labourers. Communication between farmers and labourers was the most important point which could improve relations, according to him. Farmers should tell labourers that they were valuable, but also tell them about production costs. The labourers would then "have a better understanding of the financial situation, and the importance of working carefully with equipment and effectively on the farm". To the farm labourers Visagie recommended: "Do your work passionately, as if you're working on your own farm" ${ }^{461}$ It was thus imperative that both farmers and labourers contributed to reducing antagonism instead of blaming each other.

Visagie's message could surely improve relations on some farms, but it also implied that the underlying relations should and could not be disturbed. Farmers and labourers were both "born to farm", according to him, which means that both needed each other. In a capitalist sense it is, of course, true that farmers cannot be farmers unless there are labourers, and vice versa. ${ }^{462}$ The problem was, of course, that the one was born to be a farmer and the other

\footnotetext{
459 http://www.elsenburg.com/ruraldev/Downloads/wc-farm-worker-of-the-year-manual-2012eng.pdf, 2014-05-20; Government Gazette Feb. 24, 2012, Sectoral determination 2012, p. 3.

${ }^{460}$ Farmers' Weekly, Jan. 3, 2011.

${ }^{461}$ Farmers' Weekly, Sept. 21, 2007.

${ }^{462}$ Cf. Olsson, 2018.
} 
born to be a farm labourer. Visagie's statement did not refer to farmers and labourers only as representatives of classes, but also as representatives of races. He had himself advanced on the farm and was one of the first coloured farm managers during the end of apartheid. His own career was thus an example of how a labourer could rise in positions, but without challenging the existing order based on class and race.

Another winner, Jeffrey Skermand from Paarl, explained that he had to work at the top of his ability "to ensure that the farm remains sustainable or I will end up without a job". 463 One of his initiatives was to pack grapes in the vineyard for lowered energy costs and less handling of grapes. The initiative was successful, and profitable to the farm. But Skermand was not ready to start farming on his own. He said that he had much to learn before he would venture on his own as a farmer, which Farmers' Weekly described as a wise statement. ${ }^{464}$ The competition has thus become a way for farmers to recognize the labourers, while at the same time ensuring that they will remain loyal and dependent. The relations on farms are not disrupted, but reinforced.

There is prestige for farmers in having a skilled labour force. More importantly, though, the competition is a means to improve relations between farmers and labourers and to make production efficient. Niemand explains that there was a drastic increase in the number of labourers that entered the competition after the strikes in 2012 and 2013 from some of the "hotspots" such as De Doorns, Grabouw, Citrusdal, Robertson and Elgin. In De Doorns, the number increased by 50 per cent and in Elgin it increased by more than 100 per cent. ${ }^{465}$ The farmers, who usually are the ones who enter the competitors, most likely realized that they had to take action in order to motivate the labourers, retain their loyalty and keep them from joining unions. By entering their labourers in the competition, the farmers could reinforce the relations with them, or at least they hoped to do so. Niemand also notes that the regional winner from Elgin in 2013 was a black person. The blacks

${ }^{463}$ Farmers' Weekly, Nov. 30, 2007.

${ }^{464}$ Farmers' Weekly, Nov. 30, 2007.

${ }^{465}$ Danie Niemand, Department of Agriculture, interview, 2013-11-13. 
constitute the largest share of the seasonal labourers, and were more involved in the strikes than the coloureds. By selecting a black winner, the Elgin area sent a signal that also black farm labourers were appreciated there, indicating that there was no need for blacks to strike, join the union or demand higher wages from farmers.

The role of the Western Cape government has clearly been to promote "good" relations between farmers and labourers. In that regard, the state is not a neutral party. Instead, it appears to favour and reinforce the existing relations on farms. This policy has implications for the alcohol policies and the alcohol abuse. Mercia Andrews argues that the state and especially the Department of Agriculture "have done nothing to ensure that there is the right to organize" and "it's not as if they've pushed farmers". Instead they set up various committees and promote "dualism". ${ }^{466}$ This dualism, which is aimed at improving relations by allowing both farmers and labourers to be included, does thus not solve the problem, since it does not contest the relations on farms. Further, it does not ensure that farm labourers are allowed to organize themselves independently from farmers and the state. As Andrews argues:

The government can have $[\ldots]$ development programmes and charity. But charity is not what solves problems of the rights.

There is a difference between rights and charity and that's the critical issue. $^{467}$

In other words, the work done by the government is not intended to ensure that farm labourers have the opportunity to organize and improve their own conditions, but to give them an opportunity to partake in the decisions made for their benefit. To some extent, the government programmes can be described as charity, which implies a power relation, wherein one has the opportunity to give and the other has the opportunity to receive. The handing out of charity also reinforces the relations between the farmers, the labourers and the state. At the same time the government undermines radical unions, according to Andrews. While the government thus has pro-

\footnotetext{
${ }^{466}$ Mercia Andrews, TCOE, interview, 2013-12-02.

${ }^{467}$ Mercia Andrews, TCOE, interview, 2013-12-02.
} 
grammes for upliftment of farm labourers, it does not give them opportunity to be independent.

The issue of alcohol abuse is not exclusively related to independence for farm labourers, since there are many contributing factors. However, the possibility to organize independently must be regarded as crucial in order for labourers to be able to afford to reject charity. While there can obviously be positive outcomes from the upliftment and anti-abuse programmes in the Western Cape, it is clear that many of them have also reinforced paternalism. The relations which have caused alcohol dependency have thereby not been addressed and farm labourers have not been able to improve their own conditions through negotiations with farmers on equal terms. 


\section{CONTINUITY AND CHANGE ON WINE FARMS}

From the days of slavery until the late twentieth century, the dop system was prevalent on Western Cape wine farms. The labourers initially received part of the wage in wine, and later received wine for free as a benefit. The dop system greatly enhanced alcohol problems among farm labourers and in many cases it was probably a direct cause of such ills. Pamela Scully and Wilfried Schärf have argued that the dop system was important for farmers in the reproduction of labour and in the creation of a docile labour force. This study has shown that such practices were not useful in the late twentieth and early twenty-first century. While alcohol was important to attract and retain labourers until the 1950s, and perhaps during the following decades, it is in the twenty-first century used as a reward for those labourers who "behave well" according to the employers, work well for them and take responsibility on the farm. Although alcohol is still given for free to some labourers, it is not important for the farmers to provide it in order to get labourers to stay in their employ. Instead, the way in which successful farmers attract labourers and retain their loyalty is through comparatively high wages, social upliftment and work against alcohol abuse. In that regard, the anti-alcohol abuse work has become the means to success. The farmers who have focused on social upliftment are the most successful ones. Or reversely, the successful farmers have realized that continued success depends on a loyal labour force that is skilled, paid comparatively well and treated fairly. 
From the above we can conclude that capitalist farming is based on the ability to transform production in accordance with new conditions for capital accumulation. In the 1950s, it was beneficial for farmers to give tots of wine to labourers, and many farmers also claimed that they could not find labour unless they did. But in the late 1970s and 1980s, conditions for capital accumulation began to change. Wine farmers started to focus on improving the quality of the wine, which required machinery and a skilled labour force that was sober. This process was accompanied by large-scale social upheavals and protests against the apartheid system. In order to prevent the trade unions from gaining influence in farming, farmers had various strategies, one of which was to stop using the dop system. Improved conditions on farms, but also a process of seasonalization and casualization of labour, resulted in a closer relationship between farmers and some labourers on farms. Those labourers who belong to the permanent labour force and live on the farms surely belong to the poorest sections of the working class, but they have a kind of social security, which the seasonal and casual labourers do not have. Permanent labourers do not want to become seasonal labourers, or worse, unemployed, which has reinforced bonds of loyalty with farmers.

The changed role of alcohol in wine farming underlines important aspects of South African society after apartheid, namely the process of democratic influence for the masses and continued economic hegemony for the few. While all South Africans have political freedom, the majority of the population is still economically and socially unfree in the sense that many people have little control over their lives, live in poor areas and have little opportunity to change their positions. Political rights have thus been implemented, but economic and social rights have been neglected in the transition to democracy. To some extent, it can even be argued that the peaceful transition to democracy required reassurances for capital owners that they would not be expropriated.

But in order to be able to retain their assets, capital owners were also required to implement better conditions for labourers and allow influence for trade unions. Wine farmers in the Western Cape have been at the centre of that process. They have stopped using 
the dop system, improved conditions on farms and even allowed labourers to partake in profits through BEE deals. In return, they have been able to reinforce their power and stay on the land as farmers. In other words, the farmers have adjusted to the new, democratic South Africa, and some of them have managed to profit more than they could during apartheid because of deregulation and competitiveness on the international market due to the comparatively low wages paid to labourers. Other farmers have, however, struggled more in the post-apartheid era, and have not benefitted from competition on the international market. The rise of supermarkets since the 1990s has contributed to the problems, since they have squeezed the farmers for low prices. In turn, farmers have passed on the cost of the low price to labourers through low wages, especially to seasonal labourers.

The KWV actively assisted farmers and cellars to handle trade unions. The organization also denounced the dop system in 1990 in anticipation of criticism from actors such as trade unions. For the KWV and other farmers' associations it was preferable to be proactive and deal with social issues before unions gained a foothold on farms and became influential. By improving conditions on farms, there was also a possibility that unions would be made redundant, since farm labourers would have fewer reasons to join them. But it was crucial for farmers to set the agenda for discussions about conditions on farms. By focusing on, for example, social upliftment, health issues and the dop system, which were seemingly non-political, farmers could keep politics out of farming. If discussions had been focused on land ownership, wages or apartheid itself, it would have been impossible to separate the political sphere from the farming sphere. By the 1990s, the farmers were thus beginning to get their house in order. They had started to improve housing and heavily reduced the use of the dop system. There are different numbers available for the occurrence of the dop system, but these indicate that it was used on 20 per cent of farms at the most in the 1990s.

Some of the central aspect of the preparations for trade union activity in farming were to include farm labourers in the decisionmaking process, to uplift them socially and to reward them for 
loyalty. This contributed to a closer relationship between farmers and labourers, at least the permanent labourers. It is also likely that the sanctions against South African products contributed to a closer relationship between farmers and labourers, since the ones who would suffer most from sanctions were the labourers. Farmers could stay on the land by reducing costs such as wages, but farm labourers had few options except being farm labourers.

By the mid-1990s, many farmers had thus transformed labour practices and remunerative practices to such an extent that they were prepared for farming in the post-apartheid era, when they would not be able to rely on the government for help. It was therefore relatively safe for the KWV to not only denounce the dop system, but to refer to it as an "unacceptable, obsolete and illegal practice" in 1997. By criticizing the dop system and the farmers who used it, the KWV could relate the practice to apartheid, not the present and future of wine farming. But the KWV could simultaneously point to the improvements that had been made by farmers who had stopped using the dop system. This was of importance for the reputation on the international market. The export market, primarily to Britain, was of concern to farmers' organizations such as the KWV and the exports have become increasingly important for wine farmers in the twenty-first century.

The KWV's criticism of farmers who used the dop system mirrors a larger trend in post-apartheid South Africa. Mahmood Mamdani suggests that the reconciliation process largely overlooked issues of structural inequality and exploitation. While there were few who actively participated in violation of human rights, there were many who benefitted, for example through forced labour and other coercive measures. ${ }^{468}$ To this we can add the dop system and legislation that sided with farmers. But by distancing itself from the apartheid system, the KWV shifted focus from exploitative relations on farms to the National Party.

However, although the dop system was not used by most farmers in the 1990s and was denounced by the KWV, it was defined narrowly. Only the giving of wine as part of the wage, which had

${ }^{468}$ Mamdani, 2005 
been illegal since 1928, was referred to, not the giving of wine for free, which had been the most common practice in the later half of the twentieth century. It was not illegal for farmers to give wine for free to labourers, but since there was no regulation in the law, farmers could give any amount they wanted, which contributed to alcohol problems among labourers. It appears that most farmers used such a system, also those on the successful, large estates such as Kanonkop and Bosman family vineyards. This "soft dop system" was used to keep labourers content and it also appears to have been used to reinforce ties between farmers and labourers. While farmers actively used the dop system during the nineteenth century, they could not control the drinking, according to Scully. ${ }^{469}$ But in the late twentieth century, some farmers had managed to gain control over it, and had thereby also been able to tie the labourers closer to them. On Bosman, the farmer and labourers used to drink a glass of wine together after the day's work was completed. It was a moment of social interaction between farmer and labourers. By doing so, the farmer managed to enter the sphere of drinking connected with the dop system or the soft dop system. Thereby, he gained influence in yet another part of the labourers' lives. But this system is not used in the twenty-first century.

To stop giving wine for free was probably partly caused by the new attitude of for example the KWV, but also part of an education of the labour force. By not giving wine for free to labourers, farmers instilled in them a capitalist order, based on the cash wage relationship between employer and employee. That was a new approach by farmers, who in the 1950s argued that they used the dop system to civilize labourers and teach them to drink responsibly. After the 1990s, the farmers instead tried to teach them that they could not expect people to give them things for free. Instead, they had to buy it themselves. This does not mean that the paternalist structure on farms disappeared; permanent labourers still lived on the farm and relied on the farmer for various services and benefits such as water, transport, medical treatment and education for their children. But alcohol became a commodity, which farmers sold and

${ }^{469}$ Scully, 1992, p. 59. 
labourers bought. In that regard, alcohol has been used as a means to instil a capitalist order, and its transformed role can be seen as an indication of new relations in wine farming.

The decline of the dop system did not mean that farmers stopped supplying wine to labourers. They could buy wine from the farm at a cheaper price, but were also given wine as a reward for unpaid work on committees. Such a practice is used on Kanonkop, but the farmer, Johann Krige, explains that he only gives wine to the responsible people, those who can handle it. The wine is therefore used to differentiate between labourers, and to reward and motivate them. Consequently, wine is no longer an everyday commodity that labourers are entitled to, nor is it simply a gift. It is instead a benefit that they can aim for and expect to be given if they take responsibility, work diligently and behave well according to the farmer. Farmers thus still use wine as a means of control, but in a different way than under the dop system when they supplied it in order to create docile labourers.

During the period between the 1940s and the first decade of the twenty-first century, there have been concerns about the alcohol problems among farm labourers, especially the coloured ones, in the Western Cape. In the 1940s and 1950s, the alcohol problems were even considered so severe that they posed a danger to the ability of coloured labourers to perform their work. Whites thus feared that productivity on farms and in industries would suffer as the labour force was not healthy and often drunk. The dop system was regarded as one explanation for the drunkenness among farm labourers, but it was only one of several. Poor housing and living conditions and low wages were considered as equally important explanations. The Temperance Alliance was especially critical of the dop system, and argued that it created drunkenness and addiction to alcohol. Farmers on their part defended the system and regarded it as positive for the labourers. Instead they referred to the prevalence of canteens and bars as reasons for drunkenness among labourers. The relationship between the dop system and alcohol problems was definitely strong, but not conclusive. The dop system contributed to drunkenness and did certainly not reduce the problems. However, labourers were not primarily drunk on the farms in 
the mid-twentieth century. They were perhaps in a dazed state most of the time, but they were drunk when they did not work, particularly on weekends when they visited shebeens or bars in towns or in the rural areas.

Despite the concerns about the alcohol problems, there were few initiatives to improve the situation during the 1950s, 1960s and 1970s. The Temperance Alliance criticized the dop system until the early 1960s, but then focused on white alcoholics instead. Most farmers defended the system, although there were some who did not support it and refused to use it even though many labourers still wanted tots of wine. It appears that only those farmers who had much capital had the opportunity to refuse to give wine to labourers and still be able to continue as farmers, since they could pay high enough cash wages to attract and retain labour. In that regard, the dop system was not something that farmers controlled. It was a system the farmers had established, but its reproduction was both a result of their lack of ability or will to pay high cash wages and the labourers' desire to receive wine. This is how the banning of the dop system in 1963 should be understood. The dop system was not outlawed because it was a harmful practice to labourers, but because it was a system that the progressive farmers wanted to dispose of without being forced to pay higher cash wages than what was necessary, which demonstrates how the apartheid government benefitted wine farmers. As long as the law stipulated that farmers were allowed to give a certain amount each day, labourers considered it to be their right to receive it.

The amount of alcohol given to labourers decreased between the 1940 s and early 1980s. That was to some extent a result of an increased importance of cash wages instead of rations. The tots of wine were not formally part of the wage, but nonetheless had value to both farmers and labourers. Wages in kind decreased markedly between 1955 and 1975 in wine farming districts, which indicates that the decreased use of the dop system was related to an overall transformation of remunerative practices. But there were significant differences between wine districts. In Stellenbosch, the wages were higher than elsewhere and cash wages dominated. In other districts such as Robertson wages were much lower, and rations 
made up a larger share of the wages. There was thus a stratification of farmers, which affected remunerative practices. It is highly likely that farmers in places such as Robertson gave more wine to labourers than the farmers in Stellenbosch did in the 1970s, since they had less capital and cash.

Some of the farmers who were not interested in the dop system belonged to those who wanted to improve production of wine and the entire wine industry during the 1970s and after. From 1918, the KWV had controlled most aspects of wine farming, but in the 1970s the progressive farmers argued that its influence had a negative impact on innovation, improvement of production and profit levels. Independent estate producers took the lead in the transformation of wine farming by planting new varietals, arranging wine tours and establishing a wine of origin system for certification of wine quality. Transformation of production also implied transformation of labour organization and practices. For example, cash incentives to labourers were used to improve productivity. But more importantly, mechanization implied that the farmers required a skilled labour force. Tractor drivers, irrigation specialists, pruners etc. therefore became important on farms and constituted the skilled labour force. This transformation was accompanied by new management methods, which implied that those labourers who were skilled and took responsibility were rewarded, while labourers who were not skilled and took little responsibility were not rewarded. A stratification of the labour force thereby took place. The skilled labourers constituted the core labour force on farms, while those who were not skilled became more peripheral and important mostly during harvests. Since the lack of motivation has been described as an important reason for drinking, it seems likely that these transformations resulted in less drinking among those who were skilled and had a possibility of advancing on the farm.

The transformation of production and labour relations on farms has to some extent implied that a new generation of farm labourers has emerged, which is not so much determined by age as by the social context wherein labourers live and work. That notion is in line with Karl Mannheim's view on generation as a "social phenomenon", which is based on similar experiences of historical events 
and social processes, for example from the same class position. ${ }^{470}$ Following Mannheim, we can argue that the absence of a practice such as the dop system and the focus on skill training are two factors that have formed a new generation of farm labourers in sociological terms. Labourers on estates and successful farms with a focus on quality wine, where skills and responsibility are rewarded, are more likely to belong to this new generation. Wine farmer Petrus Bosman characterizes the "new generation" of farm labourers as more motivated than the "older generation". The possibility of advancing in positions on the farm is important for their motivation, which also appears to have reduced levels of drinking, or at least the problems related to it. Drinking is clearly still "ongoing", as Mercia Andrews from TCOE puts it, but farmers such as the Bosman family argue that debt is a bigger problem than alcohol among farm labourers and that alcohol is not as big a problem as it used to be ten or fifteen years ago. It appears that it is mainly the older generation of labourers that have problems with alcohol now. It is used by all age groups, but the younger ones also use other drugs such as tik, which has become common in farming areas. However, on farms such as Bosman the labourers know that if they cause problems they will be fired. There is little acceptance for drunkenness during work, simply because it will effect production. Monday morning absenteeism, for example, has largely disappeared on Bosman, at least according to the farmer. The labourers have, like the industrial working class in England in the nineteenth century, been disciplined to practices that are required in capitalist production. ${ }^{471}$

During the twenty-first century, the dop system has been more or less eradicated. But what constitutes a problem is the so called legacy of the dop system, which is perpetual alcoholism in farming areas in the Western Cape. Foetal Alcohol Syndrome (FAS) is one of the most severe effects of that. The availability of cheap alcohol in rural areas is the main contributing factor to the perpetual alcoholism. The alcohol is often supplied in illegal shebeens, some of which are found on farms, through mobile shebeens that drive

\footnotetext{
${ }^{470}$ Mannheim, 1952, pp. 288-89, 302-04.

${ }^{471}$ Cf. Hobsbwm, 1996; Thompson, 1967.
} 
around and deliver to farms and through labourers who sell to each other. That form of supply appears to be even more harmful than the dop system. When farmers supplied wine there was some control over the amounts given, and farmers did not want labourers to be drunk during the working days. Labourers surely found other supplies of alcohol also when the dop system was used, but now their main supply is the cheap liquor, which is often sold illegally.

Compared to the dop system, the illegal sales in shebeens or by bootleggers is done for profit. Those who sell are not concerned if labourers drink too much, quite the contrary, the more they drink the better it is for the seller. Perpetual alcoholism among farm labourers in the Western Cape, often described as a legacy of the dop system, is therefore based on profits for intermediaries, who benefit from excessive drinking. But drinking is also not the same everywhere. On some farms there appear to be fewer problems, at least according to farmers, but also according to some labourers on farms. Those who drink much, or cause problems, are not so much the permanent labourers, but the seasonal or casual labourers and the farm dwellers, who have less secure employment and appear to have more problems. Or rather, they have problems because they do not have the same security as the permanent labourers.

The effects of drinking thus depend on the social position. Those who do not have proper housing, little money for food and few opportunities for health care are affected more severely by alcoholism than those who have more social security. The continuation of alcohol dependency is therefore not mainly a legacy of the dop system, since that implies that it has continued without interference from actors outside farming. Instead, it is to a greater extent a result of the transformation of wine farming, which has implied a differentiation of the labour force, increased seasonal labour and less social responsibility among farmers for those who are not permanently employed on the farm. This process of transformation has been accompanied by the supply of cheap alcohol, usually from illegal sales for profit, which means that there is little responsibility among suppliers. From this we can conclude that the structures, which uphold alcoholism and alcohol problems, have transformed, 
but not changed completely. The tradition on the farms to drink much is important, but the alcohol is now supplied by those outside farming for profit, and those who appear to suffer most are the ones who are not regularly employed and do not have social security or proper housing.

The Rural Foundation was the first organization that tried to reduce the effects of drinking, at least by reducing the use of the dop system, but the problems continued into the twenty-first century. Most efforts to reduce problems with alcohol have not implied that labourers have gained independence. Instead, the efforts to reduce problems and to uplift labourers have been characterized by a public paternalism, where the government takes on the role of the pater who is protecting the interests of farm labourers. This has been seen both on the national and the provincial level. There is certainly some difference in the approach of the government during the 1950 s and the early twenty-first century. In the 1950s, the farm labourers were not even invited to give evidence to commissions investigating alcohol problems. During the twenty-first century, the labourers have been more included, but have not been seen as responsible to solve their own problems. There is thus a discrepancy in the responsibility that farmers demand from labourers and the responsibility that they are allowed to have.

The Western Cape government has started abuse programmes and upliftment projects. Also individual farmers such as Beyers Truter have conducted work to reduce alcohol problems. While these efforts have surely been helpful to some, there is little knowledge of the efficiency. More importantly, these efforts have been within the realm of the farmers, and have in some cases been used to reproduce relations on farms, which in the first place led to alcohol problems. For example, the Farm Worker of the Year competition in the Western Cape is meant to uplift farm labourers, but it also implies a differentiation of labourers and competition between them, instead of a unity. It therefore individualizes the labourers, which reinforces individual relations between farmer and labourer.

The individualization of labourers and competition between them has been promoted since the 1980 s as a new form of man- 
agement. As the dominant form of relations on farms, it has also affected the problems with alcohol. Although alcoholism is regarded as a problem, it is regarded as an individual problem for the alcoholic. Thereby, the solutions have also been individual, for example through Beyers Truter's FAITH Fund, which focuses on changing the mind-set of those who have problems with alcohol or drugs. Instead of addressing the social circumstances such as insecure employment and housing, which cause people to drink and which enhances the negative effects of drinking, focus has thus been on the individual as the cause of the problem. Individual solutions can of course be helpful to some, but not solve the overall problem, which is structural in nature. Relations on farms, where labourers have poor working conditions, low wages, poor housing and depend on farmers, are as relevant in twenty-first century as they were in the mid-twentieth century. The seasonal labourers and farm dwellers are to some extent independent from farmers, but that independence does not generate individual freedom, since there are few other opportunities of employment.

Since the role of alcohol has transformed from being a means to create a docile labour force to being a means to motivate and reward responsible behaviour, we can conclude that farmers have managed to get their house in order. They control who lives in it, they have the only key and are ready to lock people out if they do not comply with the rules of the house. It is relevant to return to Engels, who argued that labourers in England abused alcohol much because of their poor housing and living conditions. Whereas the labourers described by Engels some decades later managed to gain more influence over the conditions under which they lived and worked, the labourers in the Western Cape have been less successful despite the political changes after 1994. They have not managed to gain influence over the production, in which the relations that cause problems are formed, and thereby not been able to phrase the problem and its solutions. Farmers, on the other hand, have been able to increase their influence over production, and have also managed to change production when conditions for capital accumulation have changed. 


\section{SOURCES AND LITERATURE}

\section{Sources}

\section{Legislation}

The Cape Town Gazette and African Advertiser, Vol. IV, Nov. 4, 1809, Proclamation 14 of 1809, Caledon, Nov. 1, 1809.

Statutes of the Union of South Africa, Liquor Act 1928 (No. 30 of 1928).

Statutes of the Republic of South Africa, Liquor Act 1963 (No. 88 of 1963).

Government Gazette, June 29, 1977, Liquor Act 1977 (No. 87 of 1977).

Statutes of the Republic of South Africa, Liquor Act 2003 (No. 59 of 2003)

Government Gazette, Nov. 28, 1997, Extension of Security of Tenure Act, 1997.

Government Gazette, Dec. 2, 2002, Sectoral determination 2002.

Government Gazette Feb. 24, 2012, Sectoral determination 2012.

Debates of the National Assembly (Hansard), 1994, vol. 2.

\section{Census and statistics}

Union of South Africa, Report on Agricultural and Pastoral Production 195455. Agricultural census (No. 29), U.G. 49/1958 Pretoria

Republic of South Africa, Report on Agricultural and Pastoral Production 1975. Agricultural census (No. 48) Pretoria.

Republic of South Africa, Population census 1991. Occupation by Development Region, Statistical Region and District. No. 03-01-08, 1991. Pretoria.

SA Wine Industry Information and Systems, South African Wine Industry Statistics (SA WIS), 2004, 2013. Elsenburg. 


\section{Select Committees and Commissions}

Union of South Africa, Report of the Wine Commission, U.G. 25- '37, Pretoria 1937.

Union of South Africa, Report of the Cape Coloured Liquor Commission of Enquiry, U.G. 33/1945, Pretoria 1945.

Union of South Africa, Report of the Select Committee on the Subject of the Liquor Bill, 1952, S.C. 8-'52, Cape Times Limited, Parow 1952.

Union of South Africa, Report of the Commission of Enquiry into the General Distribution and Selling Prices of Intoxicating Liquor, U.G. 55/1960, Pretoria 1960.

Republic of South Africa, Report of the National Manpower Commission, 1983. RP 41/1984.

Journals etc.

Farmers' Weekly 1985, 1986, 1997, 2007, 2008, 2011, 2013.

Human Rights Watch, 2011.

Temperance Bulletin, 1950.

THINK (Temperance Alliance), 1953, 1954, 1955, 1958.

Wine and Spirit, 1939.

Wynboer, 1962, 1975, 1985, 1992, 1993, 1997, 1998, 1999.

Wineland, 2000, 2002, 2003.

KWV, Annual Reports, 1969, 1972, 1979, 1987, 1988, 1989, 1990, 1991, 1992, 1997.

FAITH Fund Leaflet, Beyerskloof.

\section{Interviews}

Mercia Andrews, Trust for Community Outreach and Education, 2013-12-02.

Beyers Truter, Beyerskloof, Stellenbosch, 2013-11-26.

Anrí Truter, Beyerskloof, Stellenbosch, 2013-11-15.

Rebecca, administrator, Beyerskloof, 2013-11-15.

Jannie Bosman, Bosman Family Vineyards, Wellington, 2013-12-10.

Antonia Bosman, Bosman Family Vineyards, Wellington, 2013-12-10.

Petrus Bosman, Bosman Family Vineyards, Wellington, 2013-12-10.

Daleen Turner, consultant, Bosman Family Vineyards, 2013-12-10.

Joey Cloete, BAWUSA, Paarl, 2013-12-06.

Johann Krige, farmer, Kanonkop, Stellenbosch, 2013-12-11. 
Victoria, labourer, Kanonkop, Stellenbosch, 2013-11-27.

Lawrence, labourer, Kanonkop, Stellenbosch, 2012-11-27, 2013-12-11.

Leana Olivier, Foundation for Alcohol Related Research, 2013-10-29.

Danie Niemand, Department of Agriculture, Elsenburg, 2013-11-13.

Amelia Oberholzer, Hesketh King Treatment Centre, Muldervlei, correspondence 2014-05-12.

\section{Internet}

www.fxtop.com, 2014-05-08

http://kanonkop.co.za/wpcontent/uploads/2013/09/Kanonkop_Pricelist_April_2014.pdf, 2014-04-28.

http://www.bosmanwines.com/estate/bee.html 2014-05-14.

http://www.westerncape.gov.za/general-publication/provincial-farm-workeryear-competition, 2014-05-20.

http://www.elsenburg.com/ruraldev/Downloads/wc-farm-worker-of-the-yearmanual-2012-eng.pdf, 2014-05-20.

http://www.faithfund.co.za/what-is-foetal-alcohol-syndrome/, 2014-11-17.

\section{Literature}

Africa, Reggie, "Mechanization of South African Agriculture", in Francis Wilson (ed.) Farm Labour in South Africa. Cape Town 1977.

Ambler, Charles and Crush, Jonathan, "Alcohol in Southern African Labor History", Liquor and Labor in Southern Africa, Athens, Ohio (Pietermaritzburg) 1992.

Ball, Andrew, “Organising Farmworkers”, SA Labour Bulletin, 14:8, 1990, pp. 52-61.

Beinart, William, Twentieth-Century South Africa, Oxford 2001 [1994].

Bosch, Dawie, "The NMC and Labour Legislation for Farm Workers. The Problems and Possibilities of Negoatiated Labour Law", SA Labour Bulletin, 16:2, 1991, pp. 51-60.

Bundy, Colin, "Vagabond Hollanders and Runaway Englishmen", in William Beinart, Peter Delius and Stanley Trapido (eds.) Putting a Plough to the Ground. Accumulation and Dispossession in Rural South Africa 1850 1930, Braamfontein 1986.

Bundy, Colin, The Rise and Fall of the South African Peasantry, London 1979. 
Davies, Wendy, We Cry for our Land. Farm Workers in South Africa, Oxford 1990.

$\mathrm{du}$ Toit, Andries and Ally, F, The Externalization and Casualization of Labour in Western Cape Horticulture. A survey of Patterns in the Agricultural Labour Market in Key Western Cape Districts, and Their Implications for Employment Justice, Bellville PLAAS and CRLS 2004

du Toit, Andries, "The Micro-Politics of Paternalism. The Discourses of Management and Resistance on South African Fruit and Wine Farms", Journal of Southern African Studies, 19:2, 1993, pp. 314-336.

Ehrenreich, Tony, “Tik, Merts and Gangs. Declaration of War!” SA Labour Bulletin 33:5, 2010.

Engels, Friedrich, The Condition of the Working Class in England, London 2009 [1845].

Eriksson, Åsa, "Farm Worker Identities Contested and Reimagined: Gender, Race/Ethnicity and Nationality in the Post-strike Moment”, Anthropology Southern Africa, 40:4, 2017, pp. 248-260.

Ewert, Joachim, "A Force for Good? Markets, Cellars and Labour in the South African Wine Industry after Apartheid”, Review of African Political Economy, 39:132, 2012, pp. 225-242.

Ewert, Joachim and du Toit, Andries, “A Deepening Divide in the Countryside. Restructuring and Rural Livelihoods in the South African Wine Industry”, Journal of Southern African Studies, 31:2, 2005, pp. 315-332.

Ewert, Joachim and Hamman, Johann, "Why Paternalism Survives. Globalization, Democratization and Labour on South African Wine Farms", Sociologia Ruralis, 39:2 1999, pp. 202-221.

Falletisch, Leila, Understanding the Legacy of Dependency and Powerlessness Experienced by Farm Workers on Wine Farms in the Western Cape, unpublished MA thesis, Stellenbosch University, 2008.

Farm Labour Review. Farmworkers and Agriculture in South Africa, Farmworkers research and Resource center, Wits University 1996.

Gossage, Philip, Snell, Cudore, Parry, Charles, Marais, Anna-Susan, Barnard, Ronel, de Vries, Marlene, Blankenship, Jason, Seedat, Soraya, Hasken, Julie, May, Philip, "Alcohol Use, Working Conditions, Job Benefits, and the "Legacy" of the Dop System Among Farm Workers in the Western Cape Province, South Africa. Hope Despite high Levels of Risky Drinking”, International Journal of Environmental Research and Public Health, 11: 7, 2014, pp. 7406-7424.

Hobsbawm, Eric, The Age of Revolution. 1789-1848, New York 1996 [1962]. 
Humphries, Richard, "Administrative Politics and the Coloured Labour Preference Policy During the 1960s", in Wilmot G. James and Mary Simons (eds.) The Angry Divide. Social and Economic History of the Western Cape, Claremont 1989.

Levine, Susan, Children of a Bitter Harvest. Child Labour in the Cape Winelands, Cape Town 2013.

Lilja, Fredrik, "Inside the Enclosed Farm. Farmers Shepherds, and the Introduction of New Technology in Cape Wool Farming, 1865-1910", International Review of Social History, 63:1, 2018, pp. 63-89.

Lilja, Fredrik, The Golden Fleece of the Cape. Capitalist Expansion and Labour Relations in the Periphery of Transnational Wool Production, c. 1860-1950, Uppsala 2013.

London, Leslie, “The 'Dop' System, Alcohol Abuse and Social Control amongst Farm Workers in South Africa: a Public Health Challenge”, Social Science and Medicine, 48, 1999, pp. 1407-1414.

London, Leslie, "Alcohol Consumption among South African Farm Workers: a Challenge for Post-Apartheid Health Sector Transformation", Drug and Alcohol Dependence, 59, 2000, pp. 199-206.

Mager, Anne Kelk, Beer, Sociability and Masculinity in South Africa, Bloomington 2010.

Mamdani, Mahmood, "Amnesty or Impunity? A Preliminary Critique of the Report of the Truth and Reconciliation Commission of South Africa (TRC)", Diacritics, 32:3-4, 2005, pp. 33-59.

Mannheim, Karl, “The Problem of Generations”, in Paul Kecskemeti (ed.) Karl Mannheim. Essays on the Sociology of Knowledge, London 1952.

Marcus, Tessa, Modernising Super-Exploitation. Restructuring South African Agriculture, London 1989.

Mayson, David, The Rural Foundation, Management, and Change on Fruit Farms: a case study of selected farms in the Elgin area, Unpublished thesis, MSoc. University of Cape Town 1990.

McEwan, C and Bek, D, "Repoliticizing Empowerment. Lessons from the Wine Industry”, Geoforum, 37:6, 2006, pp. 1021-1034.

Ntsebeza, Lungile, “South Africa's Countryside. Prospects for Change from Below", in Hendricks, Fred, Ntsebeza, Lungisile and Helliker, Kirk (eds.), The Promise of Land. Undoing a Century of Dispossession in South Africa, Johannesburg 2013.

Nugent, Paul, "The Temperance Movement and Farmers at the Cape. Collective Action, Racial Discourse, and Legislative Reform, c. 1890-1965", Journal of African History, 52:3, 2011, pp. 341-363. 
Olsson, Lars, "Capital, Market, and Labour in the Western Cape Winelands c. 1900. Agricultural Capitalism?”, International Review of Social History, 63:1, 2018, pp. 29-61.

Parry, Charles and Burnhams, Nadine, "New Western Cape Liquor Laws. What is all the Fuss About?", SA Labour Bulletin, 33:2, 2009, pp. 32-34.

Parry, Charles and Bennetts, Anna, Alcohol Policy and Public Health in South Africa, Oxford, Cape Town 1998.

Rocha-Silva, Lee, Drinking in the RSA, HSRC 1985.

Schärf, Wilfried, The Impact of Liquor on the Working Class (With Particular Focus on the Western Cape). The Implications of the Structure of the Liquor Industry and the Role of the State in This Regard, Unpublished thesis, M. Soc. Sci (Criminology), University of Cape Town 1984.

Scully, "Liquor and Labour in the Western Cape, 1870-1900", in Ambler, Charles and Crush, Jonathan (eds.) Liquor and Labour in Southern Africa, Athens, Ohio (Pietermaritzburg) 1992.

Scully, Pamela, The Bouquet of Freedom. Social and Economic Relations in the Stellenbisch District, South Africa, c1870-1900, Cape Town 1990.

Shisana, Olive, Rehle, T, Simbayi, LC, Parker, W, Zuma, K, Bhana, A, Connolly, C, Jooste, S, Pillay, V, South African National HIV Prevalence, HIV Incidence, Behaviour and Communication Survey, 2005, Cape Town 2005.

Southern Africa Research Department Unit (SALDRU). "Overview of Farm Labour in South Africa", Farm Labour in South Africa, University of Cape Town 1977.

Sjölander, Jonas, Ingen enkelriktad väg till frihet, Rörelserna och berättelserna om kampen mot apartheid, Båstad 2014.

Theron, Jan, "Farm Labour in the Citrusdal Valley", Southern Africa Research Department Unit (SALDRU), Farm Labour Conference, University of Cape Town 1976.

Steyn, Hans, "Malnutrition in the Stellenbosch Area", Second Carnegie Inquiry into Poverty and Development in Southern Africa, SALDRU 1984.

Tabata, I. B., Education for Barbarism in South Africa. Bantu (Apartheid) Education, London 1960.

Thompson, E. P., “Time, Work-Discipline, and Industrial Capitalism”, Past and Present, 38, 1967, pp. 56-97.

van Onselen, Charles, "Randlords and Rotgut, 1886-1903", in Studies in the Social and Economic History of the Witwatersrand, 1886-1914. Volume 1. New Babylon, London 1982.

Viall, Jeanne, James, Wilmot and Gerwel, Jakes, Grape. Stories of the Vineyards in South Africa, Cape Town 2011. 
Vink, Nick, Williams, Gavin and Kirsten, Johanna, "South Africa", in Kym Anderson (ed.) The World's Wine Markets, Northampton 2004.

Webster, Eddie, Cast in a Racial Mould. Labour Process and Trade Unionism in the Foundries, Johannesburg 1985.

White, Fiona, “Deepening Democracy: a Farm Workers' Movement in the Western Cape", Journal of Southern African Studies, 36:1, 2010, pp. 67391.

Williams, Gavin, "Slaves, Workers, and Wine: The 'Dop System' in the History of the Cape Wine Industry 1658-1894", Journal of Southern African Studies, 42:5, 2016, pp. 893-909.

Wolpe, Harold, "Capitalism and Cheap Labour Power in South Africa. From Segregation to Apartheid", in Harold Wolpe (ed.) The Articulation of Modes of Production. Essays from Economy and Society, London 1980.

Worden, Nigel, Slavery in Dutch South Africa, Cambridge 1985. 


\section{List of acronyms}

ANC - African National Congress

AU - Agricultural Union of South Africa

BAWSI - Black Association of the Wine and Spirit Industry

BAWUSA - Bawsi and Allied Workers Union of South Africa

BEE - Black Economic Empowerment

COSATU - Congress of South African Trade Unions

CSAAWU - Commercial Stevedoring and Allied Workers Union

DA - Democratic Alliance

FAITH Fund - Foetal Alcohol Syndrome \& Interrelated Help Fund

FARR - Foundation for Alcohol Related Research

FAS - Foetal Alcohol Syndrome

FASFACTS - Foetal Alcohol Syndrome FACTS

FAWU - Food and Allied Workers Union

KWV - Koöperatieve Wijnbouwers Vereniging (Co-operative Wine Farmers' Association)

NP - National Party

RF - Rural Foundation

SAFWA - South African Farm Workers' Association

SAWSEA - South African Wine and Spirits Export Association

TCOE - Trust for Community Outreach and Education

WoF - Women on Farms

\section{List of tables}

Table 1. Coloured and black farm labourers in wine producing districts 1955 and 1991.

Table 2. Average expenditure on wages, cash and value in kind (Rand), per person in 1975 in wine farming districts.

Table 3. Ratio of wages to permanent coloured and black farm labourers

(cash and in kind) 1955 in $£$ and 1975 in $R$ in wine farming districts. 68 

The Western Cape in South Africa is famous for its wine farms and picturesque scenery. The wine industry has flourished since deregulation in the I990s and many wine farmers have become wealthy. But the people who have worked in the vineyards have been less fortunate. For centuries they were paid wages partly in wine through the infamous dop system, a practice which contributed to dependence on both alcohol and the farmers who supplied it. In the twenty-first century, such practices are rarely seen, but alcohol problems are still prevalent among farm labourers.

The dop system is often blamed for the continued existence of alcohol problems. However, this book shows that the issue is more complex and that it must be analysed in relation to the transformations that have taken place in wine farming since the I970s as a result of farmers' search for profits and adjustment to a new political climate. Especially on the estates that produce quality wine, production required better trained and more sober labourers. This development tied a core of the labourers closer to the farmers, while others were marginalized and easily turned into seasonal labourers without the social security offered through employment on farms. The book thereby highlights the structures that both contribute to and perpetuate alcohol problems.

Fredrik Lilja is a historian at Uppsala University. His research focus is on labour relations and social conditions in southern Africa. He is senior lecturer in the Department of Education, Uppsala University. This book is a result of a project funded by SIDA through the Swedish Research Council's division for Development Research and hosted by Malmö University.

ISBN 978-9I-7IO4-977-3 (print)

ISBN 978-9I-7IO4-978-O (pdf) 